SJ Quinney College of Law, University of Utah

Utah Law Digital Commons

Utah Law Faculty Scholarship

Utah Law Scholarship

$10-2018$

\title{
In Re: Petition for Appointment of a Prosecutor Pro Tempore by Jane Doe 1, Jane Doe 2, Jane Doe 3 , and Jane Doe 4 : Petition for Appointment of Prosecutor Pro Tempore
}

Paul Cassell

S.J. Quinney College of Law, University of Utah, paul.cassell@law.utah.edu

Heidi Nestel

Utah Crime Victims' Legal Clinic

Bethany Warr

Utah Crime Victims' Legal Clinic

Margaret Garvin

Defense Advisory Committee on Investigation, Prosecution, and Defense or Sexual Assault in the Armed Forces (DAC-IPAD)

Gregory Ferbrache

Ferbrache Law, PLLC

See next page for additional authors

Follow this and additional works at: https://dc.law.utah.edu/scholarship

Part of the Criminal Law Commons

\section{Recommended Citation}

Cassell, Paul; Nestel, Heidi; Warr, Bethany; Garvin, Margaret; Ferbrache, Gregory; and Hanni, Aaron H., "In Re: Petition for Appointment of a Prosecutor Pro Tempore by Jane Doe 1, Jane Doe 2, Jane Doe 3, and Jane Doe 4 : Petition for Appointment of Prosecutor Pro Tempore" (2018). Utah Law Faculty Scholarship. 134.

https://dc.law.utah.edu/scholarship/134

This Brief is brought to you for free and open access by the Utah Law Scholarship at Utah Law Digital Commons. It has been accepted for inclusion in Utah Law Faculty Scholarship by an authorized administrator of Utah Law Digital Commons. For more information, please contact

valeri.craigle@law.utah.edu. 


\section{Authors}

Paul Cassell, Heidi Nestel, Bethany Warr, Margaret Garvin, Gregory Ferbrache, and Aaron H. Hanni 
IN THE

SuPREME Court of THE StATE OF UtAH

In Re: Petition For APPointment of A Prosecutor Pro Tempore By Jane Doe 1, Jane Doe 2, Jane Doe 3, And Jane Doe 4

\section{PETITION FOR APPOINTMENT OF PROSECUTOR PRO TEMPORE}

On Original Jurisdiction to the Utah Supreme Court

Paul G. Cassell (6078)

UTAH APPELLATE CLINIC

S.J. Quinney College of Law

at the University of Utah

383 S. University St.

Salt Lake City, Utah 84112

(801) 585-5202

cassellp@law.utah.edu

Heidi Nestel (7948)

Bethany Warr (14548)

UTAH CRIME ViCTIMS' LEgAL CLINIC

3335 South 900 East, Suite 200

Salt Lake City, Utah 84106

heidi@utahvictimsclinic.org

bethany@utahvictimsclinic.org

Attorneys for Jane Doe 1, Jane Doe 2,

Jane Doe 3, and Jane Doe 4

Additional counsel on the following page

Full Briefing and Oral Argument Requested on State Constitutional Law Issues of First Impression 


\section{Additional Counsel}

Margaret Garvin (Oregon Bar 044650)

NAtional CRIME Victim LAW InstituTE at the Lewis and Clark Law School 1130 S.W. Morrison Street, Suite 200

Portland, Oregon 97205

garvin@1clark.edu

(pro hac vice application to be filed)

(law schools above are contact information only - not to imply institutional endorsement)

Gregory Ferbrache (10199)

FERBRACHE LAW, PLLC

2150 S. 1300 E. \#500

Salt Lake City, Utah 84106

gregory@ferbrachelaw.com

(801) 440-7476

Aaron H. Smith (16570)

STRONG \& HANNI

9350 South 150 East, Suite 820

Sandy, Utah 84070

asmith@strongandhanni.com

(801) 532-7080

Attorneys for Jane Doe 1, Jane Doe 2, Jane Doe 3, and Jane Doe 4 


\section{Table of Contents}

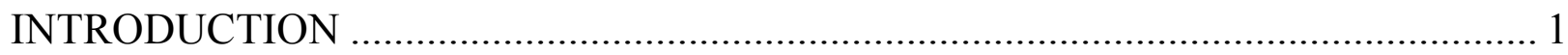

THIS COURT POSSESSES ORIGINAL JURISDICTION OVER THE

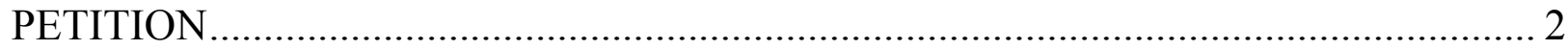

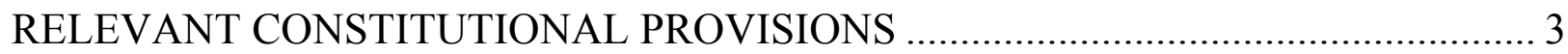

THE JANE DOES ARE ENTITLED TO PROCEED BY WAY OF

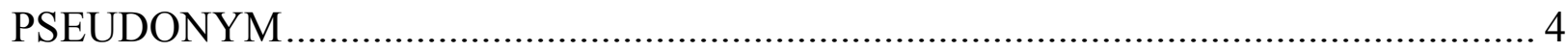

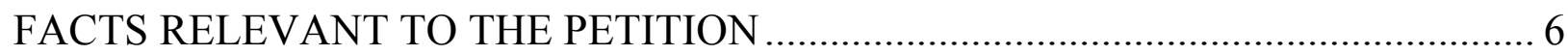

I. The Rape of Jane Doe 1 and the Non-Prosecution of Her Rapist................ 7

A. The Rape of Jane Doe 1........................................................ 7

B. The Rape of Jane Doe 1 Is a Felony Crime Under the Utah

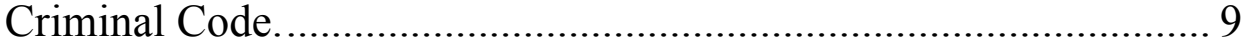

C. The Public Prosecutor Has Refused to Prosecute the Crimes

Committed Against Jane Doe 1.................................................... 10

II. The Rapes of Jane Doe 2 and the Non-Prosecution of Her Rapist............ 11

A. The Rapes of Jane Doe 2 …………………….......................... 11

B. The Rapes of Jane Doe 2 Are Felony Crimes Under the Utah

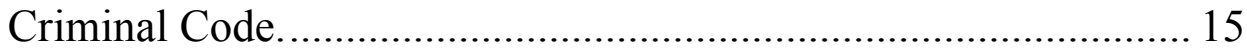

C. The Public Prosecutor Has Refused to Prosecute the Rapes

Committed Against Jane Doe 2 .................................................... 15

III. The Rape of Jane Doe 3 and the Non-Prosecution of Her Rapist.............. 15

A. The Attacks on Jane Doe 3 ......................................................... 15

B. The Attacks on Jane Doe 3 Are Felony Crimes Under the Utah Criminal Code...................................................................... 18

C. The Public Prosecutor Has Refused to Prosecute the Rapes

Committed Against Jane Doe 3.................................................... 18

IV. The Sexual Assault of Jane Doe 4 and the Non-Prosecution of Her Molester. 
A. The Sexual Assault of Jane Doe 4. ................................................. 19

B. The Sexual Assault Against Jane Doe 4 Is a Felony Crime Under the Utah Criminal Code..................................................... 21

C. The Public Prosecutor Has Refused to Prosecute the Sexual Assault Against Jane Doe 4. ......................................................... 21

I. The Court Should First to Determine the Meaning of the Relevant Utah Constitutional Provisions Without Reference to Federal Law.......... 23

II. Article VIII, Section 16 of the Utah Constitution Reflects a LongStanding Tradition of Victim-Initiated Prosecution in America.

A. America's Criminal Justice System Initially Relied on a System of Victim-Initiated Prosecution.

B. The Utah Constitutional Convention Specifically Drafted Article VIII, Section 16 to Preserve Victim-Initiated Prosecutions in Utah.

C. From 1898 Through Much of the Twentieth Century, a Victim Had a Statutory Right to Seek to Initiate a Criminal Prosecution 38

D. The 1984 Amendment to Article I, Section 16 Continued to Protect a Utah Constitutional Right for Victims to Seek a Court-Appointed Prosecutor.

III. This Court Should Use Its Power under the Court-Appointed Prosecutor Provision When a Public Prosecutor Fails or Refuses to Prosecute a Criminal Charge that is Clearly Supported by Probable Cause and Where Nothing Indicates that the Appointment Would Be Contrary to the Public Interest.

A. The Only Textual Requirement for Appointment of a

Prosecutor Under Article VIII, Section 16 is a Showing that a Public Prosecutor Has Failed or Refused to Prosecute.

B. Article VIII, Section 16 Contains an Implicit Probable Cause Requirement for the Court to Appoint a Prosecutor. 
C. The Court Can Consider Interests of Justice Under Article VIII, Section 16 in Appointing a Prosecutor. .................................. 55

D. The Victims' Rights Amendment, Utah Const., art. I, § 28, Supports Interpreting the Court-Appointed Prosecutor Provision to Allow Prosecutions that Promote Fairness to the Victim. 58

IV. Under Article VIII, Section 16, This Court Should Evaluate Whether to Appoint a Prosecutor Based on Merits of the Proposed Prosecution Rather than Evaluating the Previous Declination of the Public Prosecutor.

A. This Court's Memorandum Order in In re Hunting Mentioning an Abuse of Discretion Standard is Not Controlling Precedent on this Issue.

B. If In re Hunting is Precedential, It Should Now be Reconsidered Based on Full Briefing and Argument. 65

C. Article VIII, Section 16 Does Not Require Judicial Evaluation of the Merits of Adequacy of a Prosecutor's Declination Decision.

D. If Article VIII, Section 16 Requires Evaluation of the Adequacy of a Prosecutor's Decision, the Jane Does Are Entitled to Discovery Regarding the Basis of the Prosecutor's Decision.

V. The Court-Appointed Prosecution Provision Represents Utah's Unique Solution to the Well-Recognized Problem of UnderProsecution.

A. Victim-Initiated Prosecution Continues to Serve Valuable Social Purposes for Crime Victims and the Public at Large Today. 75

B. Victim-Initiated Prosecution Remains the Law in Many States Today. 80

VI. Each of the Four Jane Does Have Presented a Compelling Case for Appointment of a Private Prosecutor.

A. Jane Doe 1 Has Presented an Appropriate Case for the Appointment of a Prosecutor. 
B. Jane Doe 2 Has Presented an Appropriate Case for the Appointment of a Prosecutor.

C. Jane Doe 3 Has Presented an Appropriate Case for the Appointment of a Prosecutor.

D. Jane Doe 4 Has Presented an Appropriate Case for the Appointment of a Prosecutor.

VII. The Under-Enforcement of Criminal Laws Forbidding Sexual Assault Against Women by Prosecutors Further Warrants Appointment of Prosecutor.

A. Sexual Assault Against Women is a Problem of Staggering Proportions in this Country in General and Utah in Particular....... 93

B. Crimes of Sexual Violence Against Women and Girls Cause Horrific Consequences that Demand the Highest Level of Attention, Including in Utah's Criminal Justice System.

C. Decisions by Prosecutors to Decline to Prosecute Sexual Assault Crimes Disproportionately Harm Women and Girls.

D. The Salt Lake District Attorney's Office Disproportionately Fails to Prosecute Sexual Assault Crimes Committed Again Women and Girls.

E. Prosecutors' Use of a "Convictability" Standard Leads to Systemic Credibility Discounting of Women and Girls and Reliance on "Rape Myths."

F. Failure to Appoint a Prosecutor to Pursue the Well-Founded Sexual Assault Cases of Jane Doe 1, Jane Doe 2, Jane Doe 3, and Jane Doe 4 Will Lead to Institutional Betrayal of these Victims.

G. In Light of the Foregoing Facts, It Is in the Interests of Justice for the Court to Appoint a Prosecutor for the Jane Does.

H. In Light of the Foregoing Facts, The Uniform Operation of Laws Clause, Utah Constitution, Article I, Section 24, and the Equal Rights Provision, Utah Constitution, Article IV, Section 1, and the Utah Victims' Rights Amendment, Article I, Section 28, Require Appointment of a Prosecutor for the Jane Does. 
I. In Light of the Foregoing Facts, Federal Equal Protection Requires Appointment of a Prosecutor for the Jane Does.

J. Jane Doe 2 and Jane Doe 4 Are Also Entitled to Appointment of a Prosecutor Because They Were Examined by a Specially Trained Nurse from Wasatch Forensic Nurses and the Salt Lake District Attorney's Office Refuses to Use Such Nurses as Witnesses in Their Criminal Cases

VIII. For Judicial Economy and Efficiency, the Court Should Defer Briefing and Decision About Who Should Be Appointed as the Prosecutor Until It Has Decided What the Standards are for Appointment.

IX. The Jane Does Have Standing to File This Petition, But No Other Entity or Person is a Party to This Petition

X. The Court Should Hold Oral Argument on this Important Petition. 145 CONCLUSION 146

\section{Attached Addendum}

Proposed Criminal Informations for Crimes Committed Against Jane Doe 1, Jane Doe 2, Jane Doe 3, and Jane Doe 4

\section{Appendix}

Public and non-public/private versions of a numbered appendix with index are provided in separate pdf files and paper volumes. 


\section{Table of Authorities}

Federal Cases

Balistreri v, Pacifica Police Dep't,

901 F .2d 696 (9th Cir. 1990).....

130,131

Bell v. Maryland,

378 U.S., 226 (1964) 130

City of Cleburne, Tex. v. Cleburne Living Ctr.,

473 U.S. $432(1985)$

Coker v. Georgia,

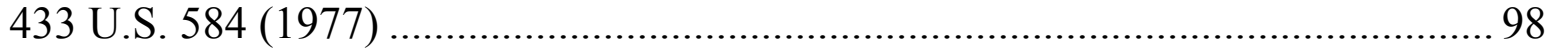

DeShaney v. Winnebago County Dep't of Soc. Servs.,

489 U.S. 189 (1989)

Elliot-Park v. Manglona,

592 F.3d 1003 (9th Cir. 2010)

Estate of Macias v, Ihde,

219 F.3d 1018 (9th Cir, 2000)

In re New Haven Grand Jury,

604 F. Supp. 453 (D. Conn. 1985) 83

Linda R.S. v. Richard D., 410 U.S. 614 (1973) . $133,134,142$

Lindsey v. Dayton-Hudson Corp., 592 F.2d 1118 (10th Cir. 1979) 5

Mikhail v. Kahn,

991 F. Supp. 2d 596 (E.D. Pa. 2014)

Mississippi Univ. for Women v. Hogan,

458 U.S. 718 (1982)

Morris v. Slappy,

461 U.S. 1 (1983) 74,75

Navarro v. Block,

72 F.3d 712 (9th Cir. 1995) 
Nevada Dep't of Hum. Res. v. Hibbs,

538 U.S. 721 (2003)

New York Trust Co. v. Eisner,

256 U.S. 345 (1921)

33,36

Payne v. Tennessee,

501 U.S. 808 (1991)

Rehberg v. Paulk,

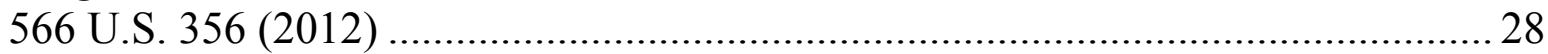

State of New Jersey $v$. Kinder,

701 F. Supp. 486 (D.N.J. 1988).............................................................. 54, 82

Steel Co. v. Citizens for a Better Environment,

523 U.S. 83 (1998)

Stewart v. Sonneborn,

98 U.S. 187 (1879)

$28,29,52$

United States v. Fritz,

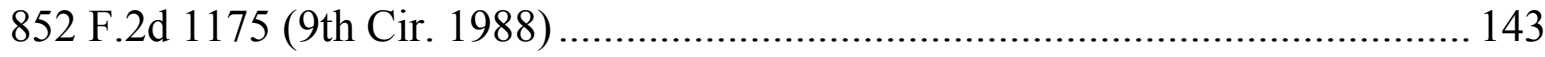

United States v. Virginia,

518 U.S. 515 (1996)

Vill. of Arlington Heights v. Metro, Hous. Dev. Corp.,

429 U.S. 252 (1977)

Voytko v. Ramada Inn of Atlantic City,

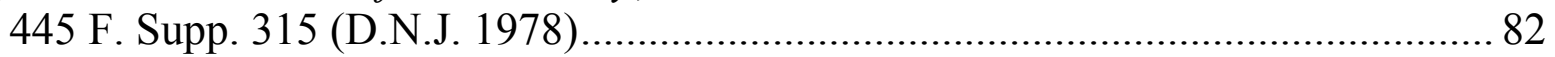

Whren v. United States,

517 U.S. 806 (1996)

Yick Wo v. Hopkins,

118 U.S. $356(1886)$ 130

Young v. U.S. ex rel. Vuitton et Fils S.A.,

481 U.S. 787 (1987) 79,80

Ziglar v. Abbasi,

137 S. Ct. 1843 (2017) 123,124 
$\underline{\text { State Cases }}$

Adams v. State,

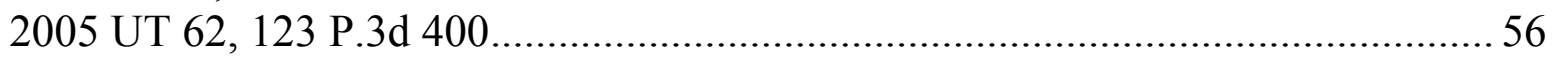

Allen v. Rampton,

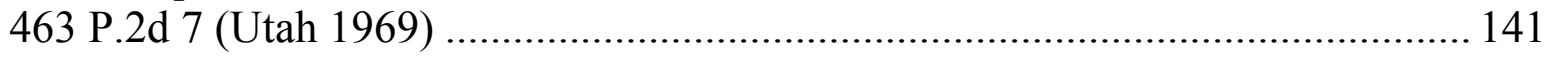

Am. Bush v. City of S. Salt Lake, 2006 UT 40, 140 P.3d 1235.

$24,25,45,60$

Am. Fork City v. Crosgrove,

701 P.2d 1069 (Utah 1985) 33

Brack v. Wells,

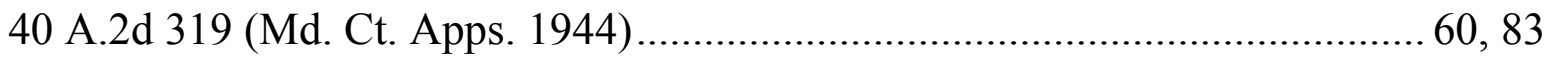

Bradford v. Knights,

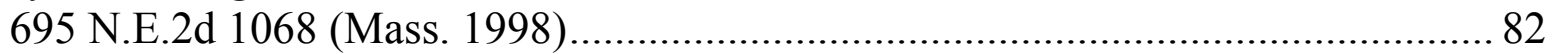

Brant v. McSoley,

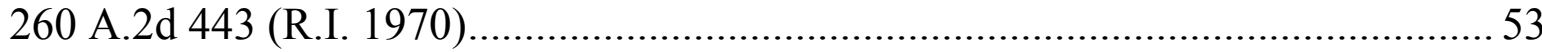

Brigham City v. Stuart,

2005 UT 13, 122 P.3d 506. 145

Commonwealth v. Benz,

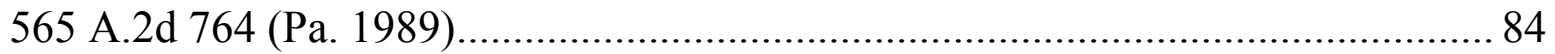

Cox v. Cox,

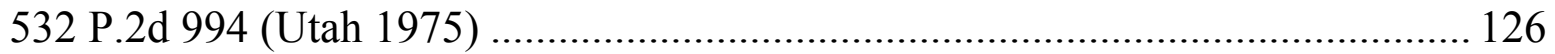

Cronan ex rel. State v. Cronan,

774 A.2d 866 (R.I. 2001).

$80,81,133$

Darrin v. Gould,

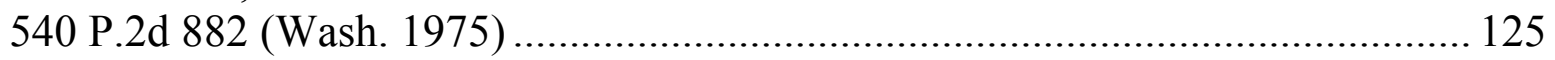

Drake v Industrial Comm'n of Utah,

939 P.2d 177 (Utah 1997)

Eldridge v. Johndrow,

2015 UT 21, 345 P.3d 553

$64,65,66$

Eskelson ex rel. Eskelson v. Davis Hosp. \& Med. Ctr.,

2010 UT 59, 242 P.3d 762.

104, 107, 108 
Fox v. MCI Commc'ns Corp.,

931 P.2d 857 (Utah 1997)

Gallivan v. Walker, 2002 UT 89, 54 P.3d 1069

$119,120,121$

Gardner v. Board of County Comm'rs of Wasatch County, 2008 UT 6, 178 P.3d 893 5

Grand County v. Rogers,

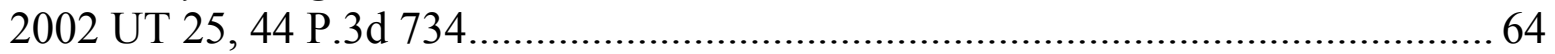

Gregory v. Shurtleff,

2013 UT 18, 299 P.3d 1098

passim

Hansen v. Barlow, 456 P.2d 177 (Utah 1969)

Hansen v. Utah State Retirement Bd.,

652 P.2d 1332 (Utah 1982)

Hodges v. Gibson Products Co.,

811 P.2d 151 (Utah 1991) ..... 54,58

In re Petition of Thomas, 434 A.2d 503 (Me. 1981) 83

In re Request for Appointment of Special Prosecutor by Eric Hunting,

No. 960558, 930 P.2d 904 (Mem. 1997). 62,63

In re Request for Appointment of Special Prosecutor by Eric Hunting,

No. 960558, 939 P.2d 177 (Mem. 1997) 60,61

In re Young,

1999 UT 6, 976 P.2d 581 25,29

Jenkins v. State,

585 P.2d 442 (Utah 1978) 142

Jensen ex rel. Jensen v. Cunningham, 2011 UT 17, 250 P.3d 465. 23,123

King v. Second Nat'l Bank \& Trust Co.,

173 So. 498 (Ala. 1937) 83 
Kopp v. Salt Lake City,

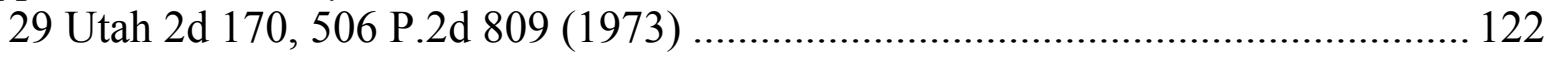

M.J. v. Wisan,

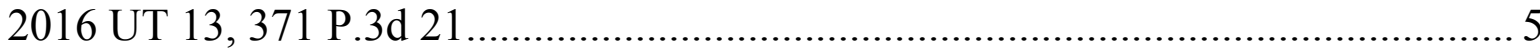

Moczygemba v. State,

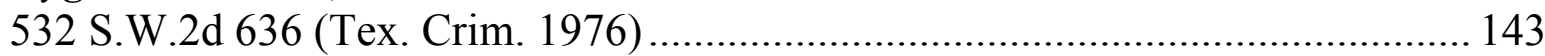

Mouty v. The Sandy City Recorder,

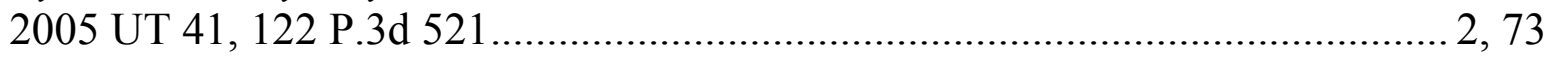

Ohio v. Ray,

143 N.E.2d 484 (Ohio App. 1956) …………………............................... 80, 81

Parker v. Dodgion,

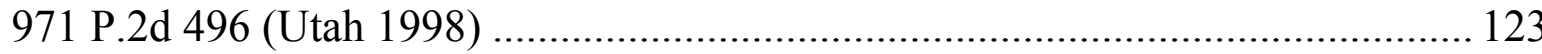

People v. Clancey,

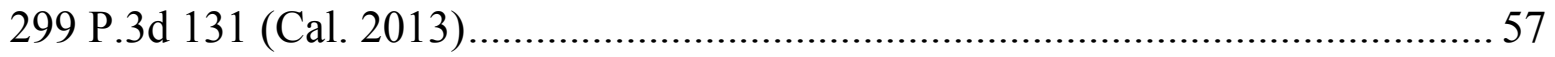

Puseyv. Pusey,

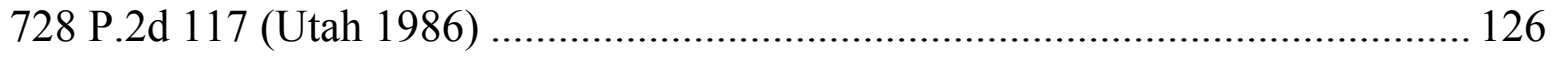

Rand v. Rand,

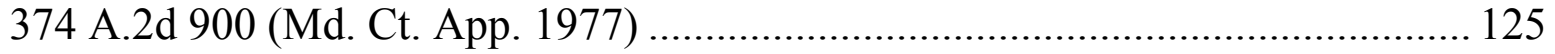

Richardson v. Treasure Hill Mining Co.,

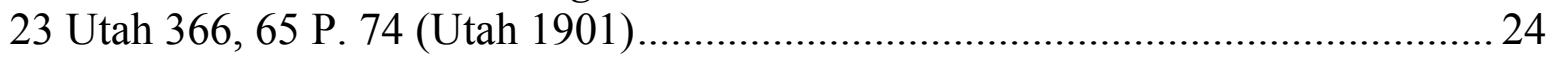

Ritchie v. Richards,

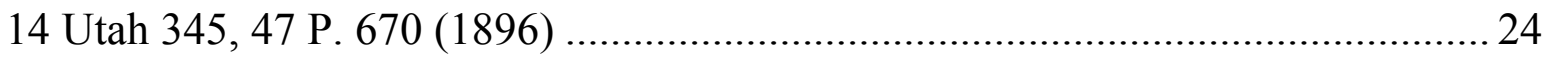

Salt Lake City v. Peterson,

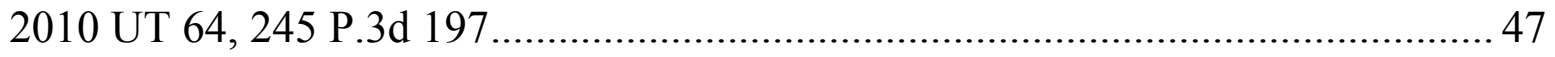

Salt Lake City v. Wilson,

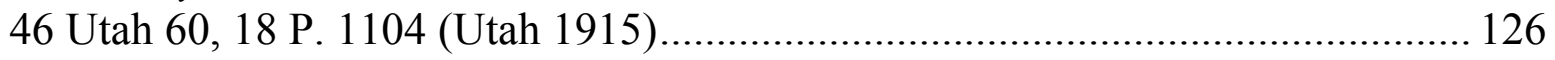

Society of Separationists, Inc. v. Whitehead,

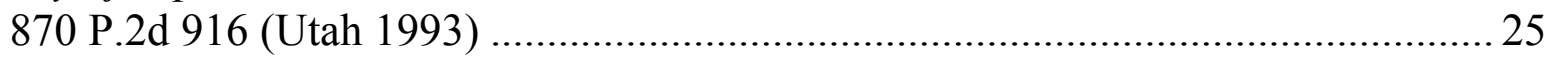

Spencer v. Utah State Bar,

2012 UT 92, 293 P.3d 360 
State v. Balfour,

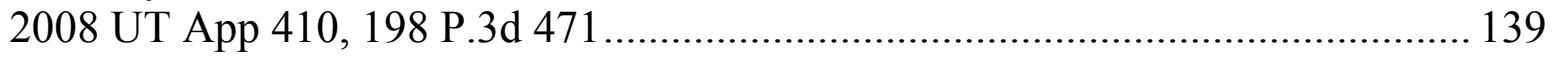

State v. Barela,

2015 UT 22, 349 P.3d 676.

$86,89,90$

State v. Blake, 2002 UT 113, 63 P.3d 56 passim

State v. Brown, 2014 UT 48, 342 P.3d 239

State v. Cady, 2018 UT App 8, 414 P.3d 974. 87

State v. Canton, 2013 UT 44, 308 P.3d 517. passim

State v. Christiansen, 2015 UT 74, 365 P.3d 1189 48

State v. Drej, 2010 UT 35, 233 P.3d 476.

State v. Elliott,

13 Utah 200, 44 P. 248 (1896) 24

State v. Fry, 2010 WL 4550716 (N.M. App. 2010) 5

State v. Hernandez, --P.3d---, 2018 WL 3865317 50

State v. Houston, 2015 UT 40, 353 P.3d 55. $25,29,63$

State v. Jessen, 633 P.2d 410 (Ariz. 1981) 143

State v. Jiminez,

588 P.2d 707 (Utah 1978) ..... 54

State v. Mauchley, 2003 UT 10, 67 P.3d 477 (Utah 2003). 66 
State v. Mohi,

901 P.2d 991 (Utah 1995)

$61,62,65$

State v. Murphy,

584 P.2d 1236 (Idaho 1978).

81

State v. Roberts,

2015 UT 24, 345 P.3d 1226. 122

State v. Robertson,

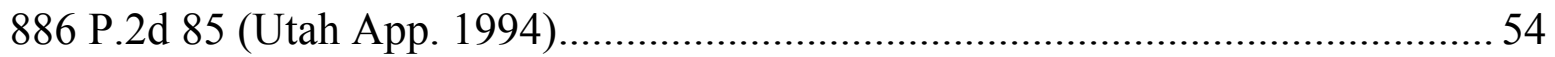

State v. Robertson,

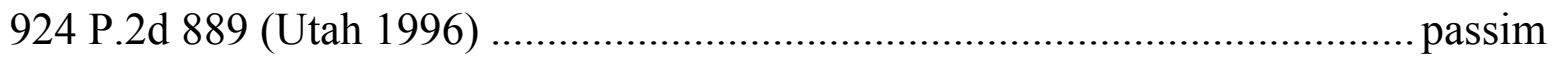

State v. Robison, 2006 UT 65, 147 P.3d 448 64

State v. Schmidt,

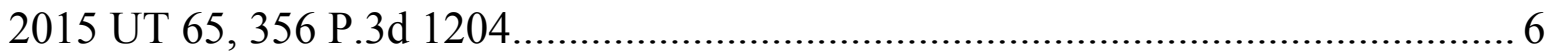

State v. Span,

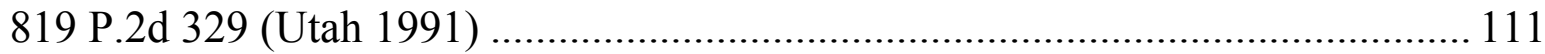

State v. Spencer,

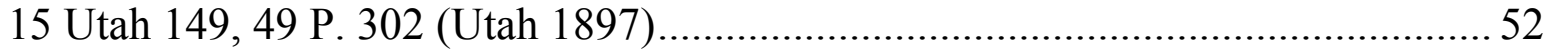

State v. Sullivan,

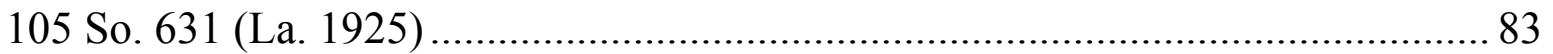

State v. Unnamed Defendant,

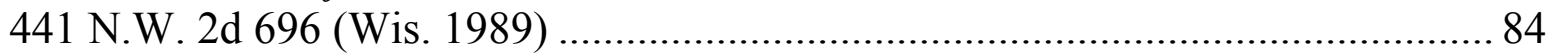

State v. Virgin,

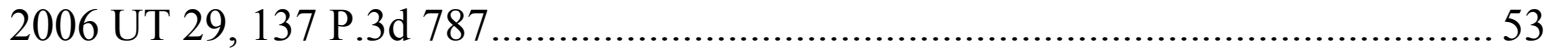

State v. Woodmansee, 35 A. 961 (R.I. 1896). 76

State v. Worwood,

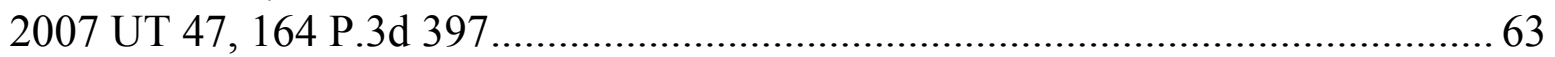

State ex rel. Master v. Cleveland, 661 N.E.2d 180 (Ohio 1996) 68 
State ex rel. Miller v. Smith,

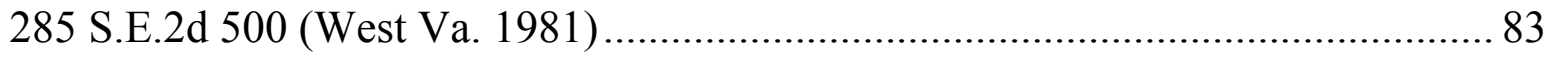

State ex rel. Wild v. Otis,

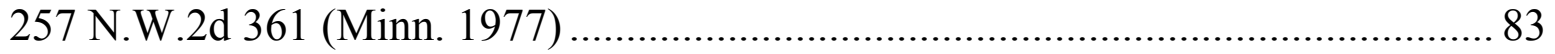

Tintic Standard Mining Co. v. Utah Cty.,

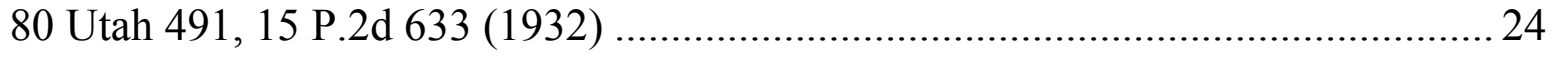

Utah Chapter of Sierra Club v. Utah Air Quality Bd.,

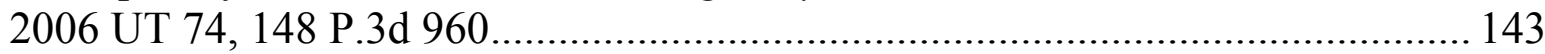

Watson v. Watson,

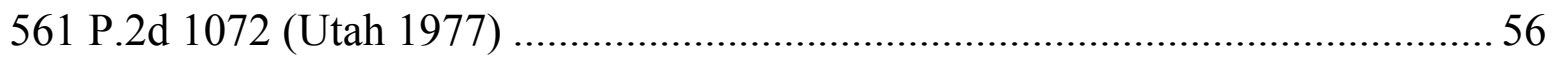

Watts v. Civil Serv. Bd. for Columbia,

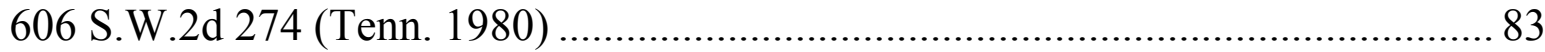

West v. Thomson Newspapers,

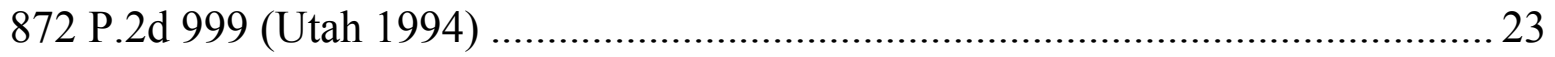

Zimmerman v. Univ. of Utah,

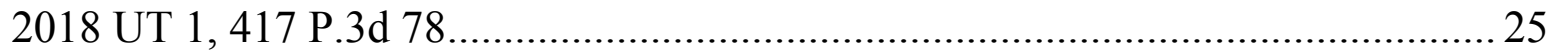

Constitutional Provisions

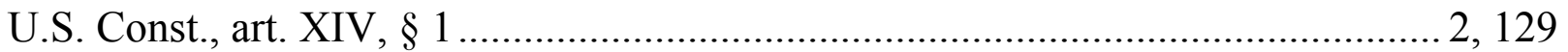

La. Const., art. I, § 3

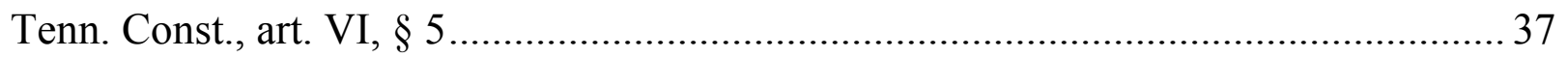

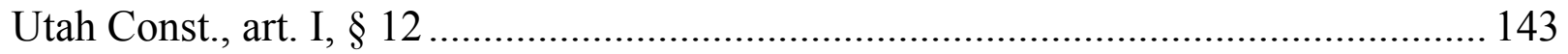

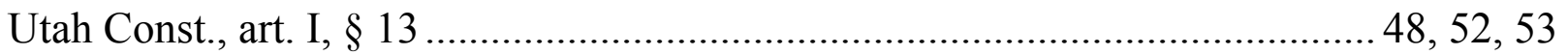

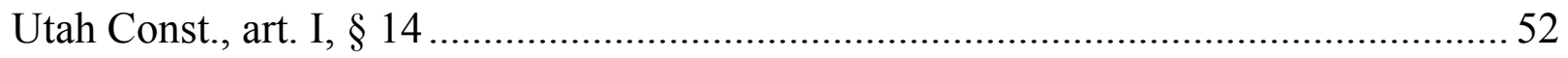

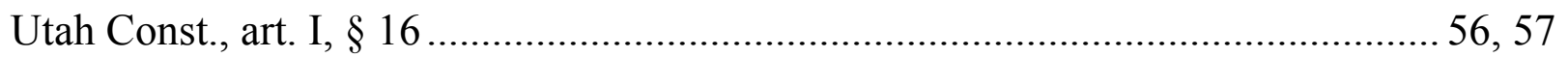

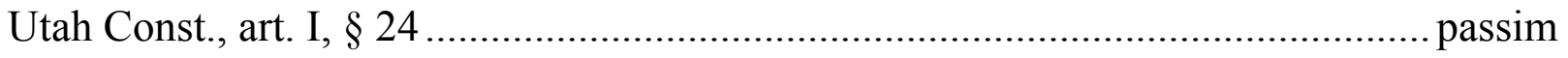

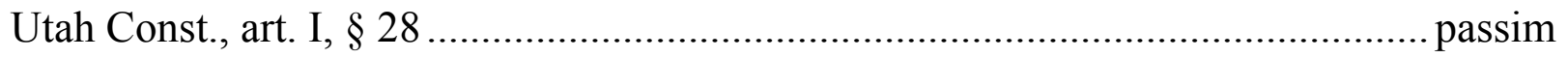

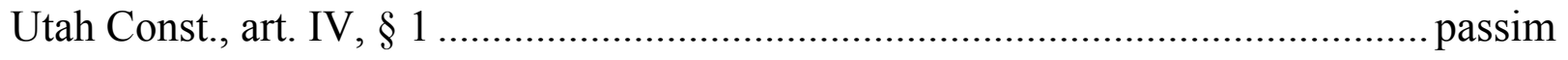

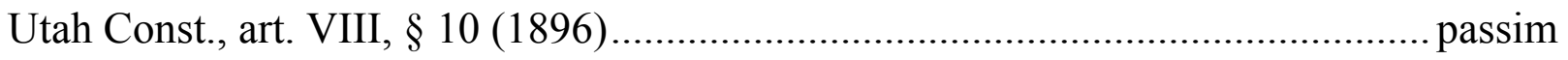




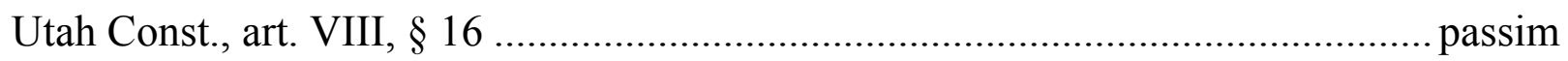

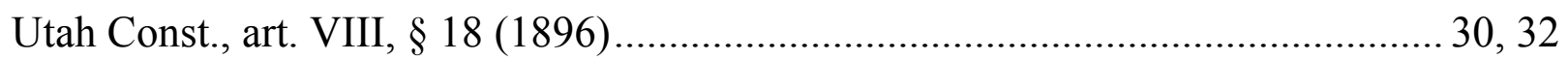

$\underline{\text { Statutes }}$

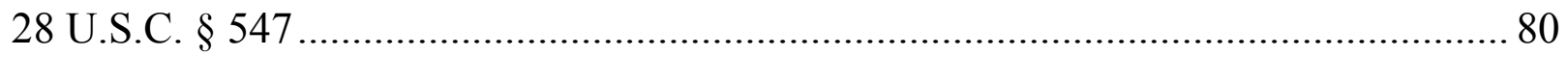

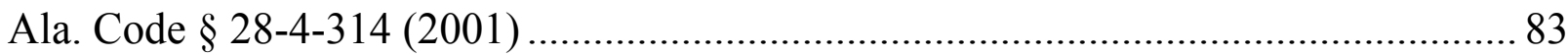

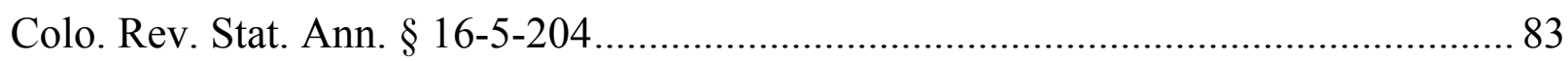

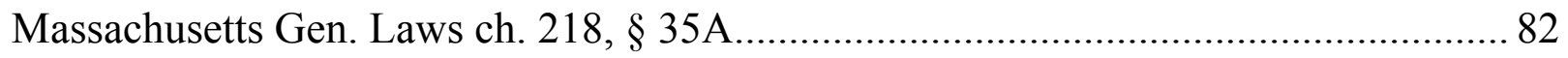

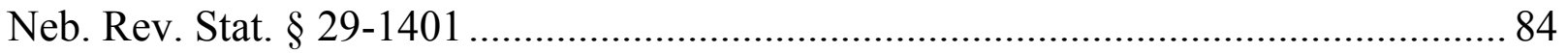

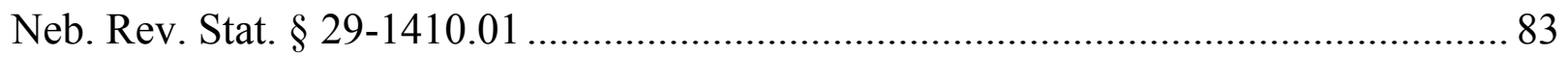

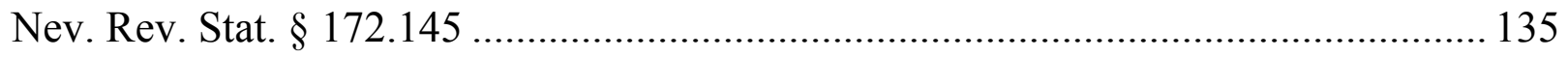

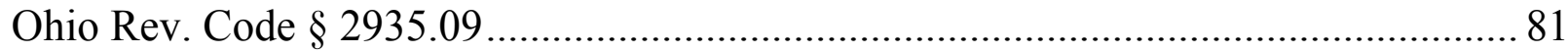

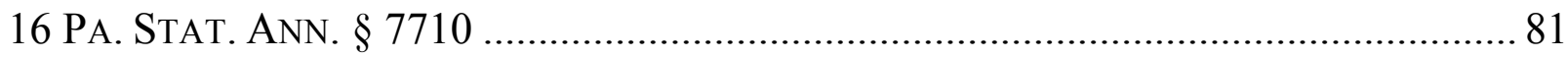

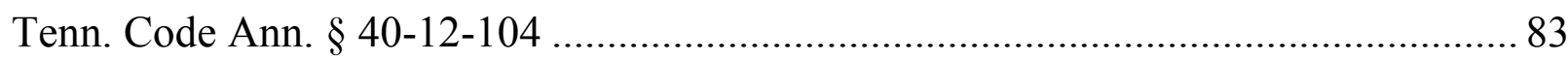

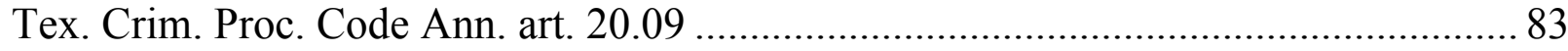

Utah Code $\S$ 76-5-402 ……..................................................................... 9, 14, 17

Utah Code § 76-5-402.2 ............................................................... 10, 14, 15, 20

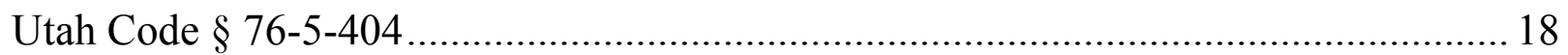

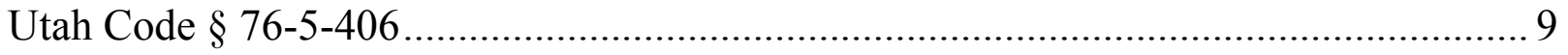

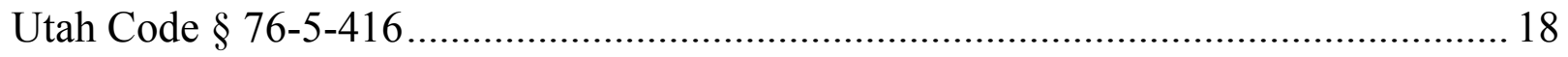

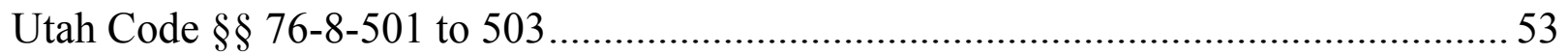

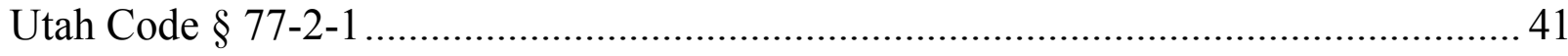

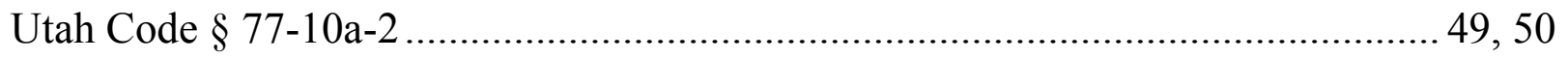

Utah Code § 77-10a-3 ….............................................................................. 49, 50

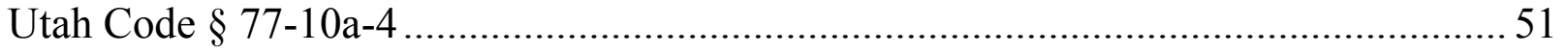




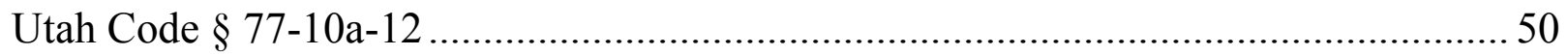

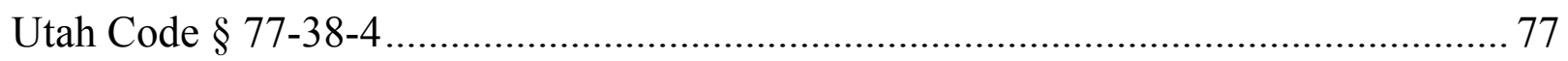

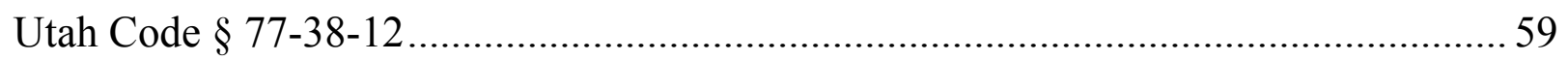

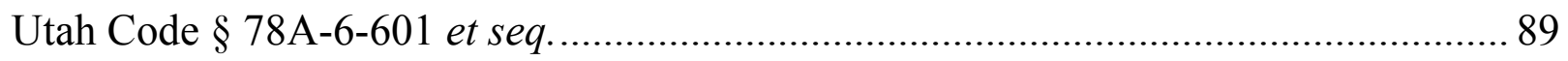

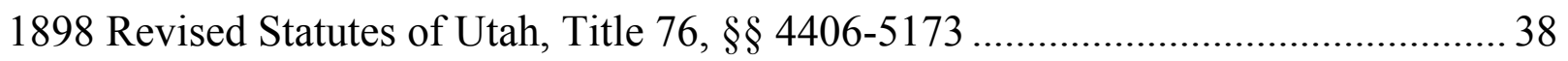

$\underline{\text { Rules }}$

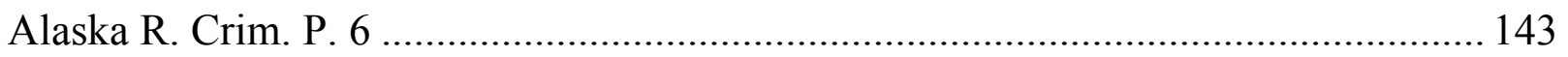

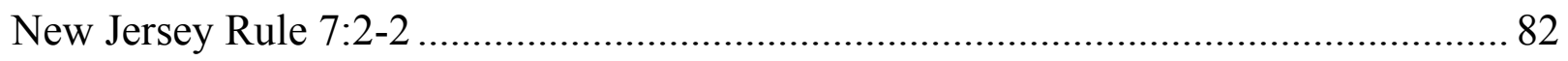

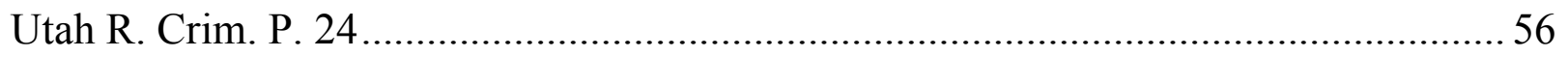

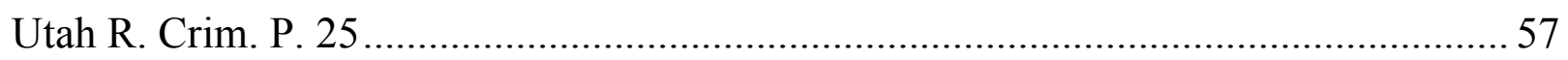

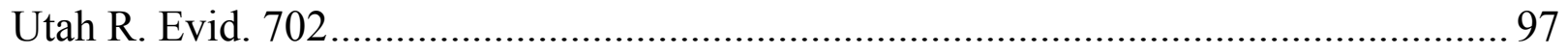

Utah R. Prof. Conduct 3.8

Law Journals and Reviews

Abrahamson, Shirley S., Redefining Roles: The Victims' Rights Movement, 1985 UTAH L. REV. 517.

Abrams, Norman,

Internal Policy: Guiding the Exercise of Prosecutorial Discretion, 19 UCLA L. REV. 1 (1971)...................................................................... 70, 71

Avalos, Lisa R.,

Policing Rape Complainants: When Reporting Rape Becomes A Crime,

20 J. Gender Race \& Just. 459 (2017).

Aynes, Richard L.,

Constitutional Considerations: Government Responsibility and

the Right Not to be a Victim,

11 Pepp. L Rev. 63 (1984).

Baude, William,

Is Qualified Immunity Unlawful?,

106 CAL. L. REV. 45 (2018) 
Bedera, Nicole \& Kristjane Nordmeyer,

"Never Go Out Alone": An Analysis of College Rape Prevention Tips,

19 SeXuality \& Culture 533 (2015)

Beloof, Douglas E.,

The Third Model of Criminal Process: The Victim Participation Model,

1999 UTAH L. REV. 289.

Beloof, Douglas E., Paul G. Cassell, Margaret Garvin \& Steven J. Twist,

VICTIMS In CRIMINAL PROCEDURE ( $4^{\text {th }}$ ed. 2018)

$50,51,75,79$

Breiding, Matthew J. \& Brian S. Armour,

The Association Between Disability And Intimate Partner Violence In

The United States, 25(6) ANNALS OF EPIDEMIOLOGY 455 (2015) .98

Bryden, David P.,

Redefining Rape,

3 BufF. CRIM. L. REV. 317 (2000) 103,104

Campbell, R., D. Patterson \& L. Lichty, The Effectiveness of Sexual Assault Nurse Examiner (SANE) Programs:

A Review of Psychological, Medical, Legal, and Community Outcomes, 6 Trauma, Violence, AND Abuse 1 (2005).

Cardenas, Juan,

The Crime Victim in the Prosecutorial Process,

9 HARV. J.L. \& PUB. POL'Y 357 (1986)

Cassell, Paul G.,

Balancing the Scales of Justice: The Case for and Effects

of Utah's Victims' Rights Amendment,

1994 UTAH L. REV. 1373.

$58,59,75$

Cassell, Paul G.,

The Mysterious Creation of Search and Seizure Exclusionary

Rules Under State Constitutions: The Utah Example

1993 UTAH L. REV. 751 (1993).

Cassell, Paul G.,

Search and Seizure and the Utah Constitution:

The Irrelevance of the Antipolygamy Raids,

1995 BYU L. REV. 1 34,35 
Chen, Laura P., et al.,

Sexual Abuse and Lifetime Diagnosis of Psychiatric Disorders:

Systematic Review and Meta-analysis,

85 MAYO Clin Proc. 619 (July 2010) ........................................................... 98, 99

Christiansen, Jeremy M.,

Some Thoughts on Utah Originalism: A Response,

2014 UTAH L. REV. ON LAW 1

Comment, Private Prosecution: A Remedy for District

Attorneys' Unwarranted Inaction,

65 YALE L.J. 209 (1955)

Davis, Peter L.,

The Crime Victim's "Right" to a Criminal Prosecution: A Proposed

Model Statute for the Governance of Private Prosecutions,

38 DePAul L. Rev. 329 (1989)

De Bellis, Michael D., et al.,

Neurodevelopmental Biology Associated with

Childhood Sexual Abuse, 20 J. CHILD SEXUAL ABUSE 548 (2011).

Fairfax, Roger A. Jr., Delegation of the Criminal Prosecution Function to Private Actors, 43 U.C. DAVIS L. REV. 411 (2009)...

Fairfax, Roger A. Jr.,

The Grand Jury's Role in the Prosecution of Unjustified Police

Killings - Challenges and Solutions,

52 HARV. C.R.-C.L. L. REV. 397 (2017)

Fitzsimons, Nancy M., Justice for Crimes Victims with Disabilities in the Criminal

Justice System: An Examination of Barriers and Impetus for Change,

13 U. ST. THOMAS L.J. 33 (2016)

88,97

Friedman, Lawrence,

State Constitutions and Criminal Justice in the Late Nineteenth Century,

53 Albany L. Rev. 265 (1989). 35

Gasjins, Richard, Changes to the Criminal Law in Eighteenth Century Connecticut, 25 AM. J. LEGAL HIST. 309 (1981). 
Gifford, Donald G., Equal Protection and the Prosecutor's Charging

Decision: Enforcing an Ideal, 9 GEO. WASH. L. REV. 659 (1981)

Gittler, Josephine,

Expanding the Role of the Victim in a Criminal Action:

An Overview of Issues and Problems,

11 Pepperdine L. Rev. 117 (1984).

Goldstein, Abraham S.,

Defining the Role of the Victim in Criminal Prosecution,

52 Miss L.J. 515 (1982).

Hindus, Michael S.,

The Contours of Crime and Justice in Massachusetts

and South Carolina, 1767-1878,

21 AM. J. LEGAL. Hist. 212 (1977)

Ireland, Robert M.,

Privately Funded Prosecutors in the Nineteenth Century United States,

39 AM. J. LEGAL HIST. 43 (1995)

Kilpatrick, Dean G. \& Randy K. Otto,

Constitutionally Guaranteed Participation in Criminal Proceedings

for Victims: Potential Effects on Psychological Functioning,

34 WAYNE L. REV. 7 (1987).

75,76

Langbein, John H.,

The Criminal Trial Before the Lawyers,

45 U. CHI. L. REV. 263 (1978).

Lawson, Tamara F.,

A Shift Towards Gender Equality in Prosecutions:

Realizing Legitimate Enforcement of Crimes Committed Against

Women in Municipal and International Criminal LAW,

33 S. ILL. U. L.J. 181 (2009)

Lloyd, William H. Jr.,

The Courts of Pennsylvania in the Eighteenth Century Prior to the

Revolution, 56 U. PA. L. REV. 28 (1908)...

McConville, Mike \& Chester Mirsky,

The Rise of Guilty Pleas: New York, 1800-1865,

22 J.L. \& SOC'Y 443 (1995) 30 
McCormack, Michael T.,

The Need for Private Prosecutors: An Analysis

of Massachusetts and New Hampshire Law,

37 SufFolK U. L. REV. 497 (2004)

McDonald, William F.,

Towards a Bicentennial Revolution in Criminal

Justice: The Return of the Victim,

13 AM. CRIM. L. REV. 649 (1976)

27,28

Michel, Verónica \& Kathryn Sikkink,

Human Rights Prosecutions and the Participation

Rights of Victims in Latin America,

47 LAW \& SOC'Y REV. 873 (2013). 84

Nelson, William E.,

Emerging Notions of Modern Criminal Law in the

Revolutionary Era: An Historical Perspective,

42 N.Y.U. L. REV. 450 (1967).

Note, Private Challenges to Prosecutorial Inaction:

A Model Declaratory Judgment Statute,

97 YALE L.J. 488 (1988). 77,83

Note, The Use of Mandamus to Control Prosecutorial Discretion,

13 AM. CRIM. L. REV. 563 (1976)

O’Neill, Michael Edmund,

Private Vengeance and the Public Good,

12 U. PA. J. CONST. L. 659 (2010).

Panek, Tracy,

Search and Seizure in Utah: Recounting the Antipolygamy Raids,

UTAH Hist. Q. 317 (1994)

Robertson, Caleb J.,

Restoring Public Confidence in the Criminal Justice

System: Policing Prosecutions When Prosecutors Prosecute Police,

67 Emory L.J. 853 (2018).

Seidman, Ilene \& Susan Vickers,

The Second Wave: An Agenda for the Next Thirty Years of Rape Law

Reform, 38 SufFolk U. L. REV. 467 (2005). 5 
Smith, Brad C.,

Comment, Be No More Children: An Analysis of Article I,

Section 4 of the Utah Constitution, 1992 UTAH L. REV. 1431

Spindel, Donna J.,

The Administration of Justice in North Carolina, 1720-1740,

25 AM. J. LEGAL HIST. 141 (1981).

Spohn, Cassia, Dawn Beichner \& Drika Davis-Frenzel,

Prosecutorial Justification for Sexual Assault Case Rejection: Guarding

the "Gateway to Justice", 48 Soc. Probs. 206 (2001)....

Steinberg, Allen,

From Private Prosecution to Plea Bargaining: Criminal Prosecution,

the District Attorney, and American Legal History,

30 CRIME \& DELINQ. 568 (1984).

Surrency, Edwin,

The Evolution of an Urban Judicial System: The Philadelphia Story,

1683-1968, 18 AM. J. LEGAL Hist. 95 (1974).....

Tuerkheimer, Deborah

Incredible Women: Sexual Violence and the Credibility Discount, 166 U. PA. L. REV. 1 (2017) passim

Tuerkheimer, Deborah, Underenforcement as Unequal Protection,

57 B.C. L. REV. 1287 (2016) 103,132

Vorenberg, James,

Decent Restraint of Prosecutorial Power,

94 HARV. L. REV. 1521 (1981). 70,77

Wainstein, Kenneth L.,

Judicially Initiated Prosecution: A Means of Preventing

Continuing Victimization in the Event of Prosecutorial Inaction,

76 CAL. L. REV. 727 (1988).

Welling, Sarah N.,

Victims in the Criminal Process: A Utilitarian Analysis

of Victim Participation in the Charging Decision,

30 ARIZ. L. REV. 83 (1988) 
White, Jean B.,

Prelude to Statehood: Coming Together in the 1890s,

62 UtAH HisT. Q. 300 (1994).

White, Jean Bickmore,

Woman's Place Is in the Constitution: The Struggle for Equal Rights in

Utah in 1895, UTAH HIST. Q. 344 (fall 1974)

Woolhandler, Ann \& Caleb Nelson,

Does History Defeat Standing Doctrine?,

102 Mich L. REV. 689 (2004) 30

Other

Attorney General Opinion,

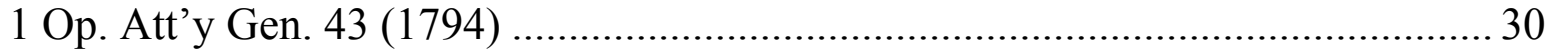

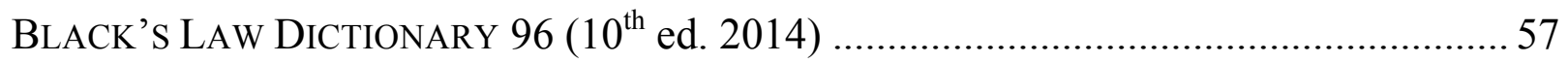

Blackstone, William,

COMMENTARIES ON THE LAWS OF ENGLAND, Vol. IV, Ch. 1

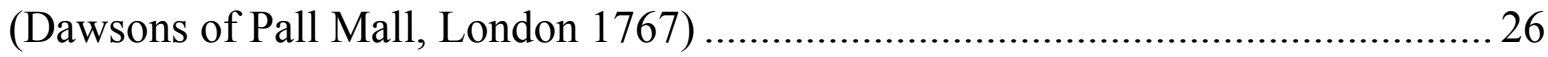

Centers for Disease Control and Prevention,

Nat'l Ctr. for Injury Prevention and Control,

Fact Sheet on Sexual Violence in Youth (2012), available at

https://www.cdc.gov/violenceprevention/pdf/2012FindingsonSVinYout

h.pdf.

96,100

Centers for Disease Control and Prevention,

Sexual Violence: Consequences, available at

https://www.cdc.gov/violenceprevention/sexualviolence/consequences.h

tml

de Tocqueville, Alexis,

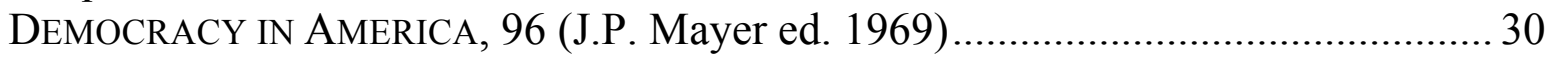

Elman, R. Amy,

Confronting the Sexual Abuse of Women with Disabilities,

VAWnet, National Online Resource Center on Violence Against

Women 2-3 (Jan. 2005).

Fanflick, Patricia L.,

Victim Responses to Sexual Assault: Counterintuitive or Simply

Adaptive?, Special Topics Series, Nat'1 Dist. Attorneys Ass'n (2007). 
Frohmann, Lisa,

Constituting Power in Sexual Assault Cases: Prosecutorial Strategies

for Victim Management, 45 Social PROBS. 393, 395 (1998)

Gossel, Collin,

Women Are Revealing All the Things They'd Enjoy Doing if Men Had a

Curfew I Eye-Opening Thread, Oct. 2, 2018, available at

https://www.georgetakei.com/women-men-curfew-9pm-twitter-

2609495872.html

Headrick, Mike \& Tania Mashburn,

Data Reveals Few Utah Rape Cases Prosecuted, Nov. 13, 2014,

available at https://www.ksl.com/?sid=32340680\&nid=1171

Larson, Gustive O.,

THE “AMERICANIZATION” OF UTAH FOR STATEHOOD 302 (1971)

Majority Staff of the Senate Committee on the Judiciary, 102d Cong., The Response to Rape: Detours on the

Road to Equal Justice, 2, (1993)

Mitchell, Christine \& Benjamin Peterson, CCJJ, 2007 Rape in Utah Survey, 2 (2008), available at

https://justice.utah.gov/Documents/Research/SexOffender/RapeinUtah2

007.pdf

Murphy, Colleen, Another Challenge on Campus Sexual Assault: Getting Minority

Students to Report It, CHRON. HIGHER EDUC. (June 18, 2015), available

at https://www.chronicle.com/article/Another-Challenge-on-

Campus/230977

Offense of Rape After Withdrawal of Consent,

33 A.L.R.6th 353 (2008 and 2018 Supp.)

Petition sent to Congress in 1876 ,

H.R. Misc. Doc. No. $42,44^{\text {th }}$ Cong., $1^{\text {st }}$ Sess. 1 (1876).

Planty, Michael, et al.,

U.S. Dep't of Justice, Bureau of Justice Statistics,

Female Victims of Sexual Violence, 1994-2010 (2013), available at

https://www.bjs.gov/content/pub/pdf/fvsv9410.pdf. 93 
Polusny, Melissa A. \& Paul A. Arbisi, Assessment of Psychological Distress and Disability After Sexual Assault in Adults, in PsyChOLOGICAL KNOWLEDGE In COURt 97

(Gerald Young et al. eds., 2006). 99

Preface,

1898 Revised Statutes of Utah

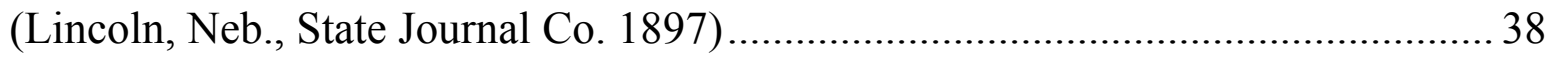

PRESIDENT's TASK ForCE ON ViCTIMS OF CRIME, FINAL REPORT (1982)...................... 75

Rape in the United States: The Chronic Failure to Report and Investigate

Rape Cases, Hearing Before the Subcomm. on Crime and Drugs, Sen.

Jud. Comm., 111th Cong. 27 (2010) 100,101

Rape Victims' Access to Justice: Understanding and Combatting

Pervasive Rape Myths, NCVLI Victim Law Bulletin (Nat'l Crime

Victim Law Inst., Portland, Or.), Apr. 2014, available at

https://law.lclark.edu/live/files/16725-ncvlivawrape-victims-access-to 103

ReCording of Spec. Sess. Discussion of SubStitute SJR 1, Held by

the Senate OfFice of the Utah Legislature (March 26, 1984) 44

Roe, Ginna,

One Year After \#MeToo Movement Started, Salt Lake Sees Spike in

Sexual Assault Reports, Sept. 26, 2018,

https://kutv.com/news/local/one-year-after-metoo-movement-started-

salt-lake-sees-spike-in-sexual-assault-reports

Sinozich, Sofi \& Lynn Langton,

U.S. Dep't of Justice, Rape and Sexual Assault Victimization Among

College-Age Females, 1995-2013 (2014). 95,96

Spohn, Cassia \& Katharine Tellis,

Nat'l Criminal Justice Reference Serv., Policing \& Prosecuting Sexual

Assault in Los Angeles City \& County: VI-VII (2012), available at

https://www.ncjrs.gov/pdffiles1/nij/grants/237582.pdf.

Staff of Sen. Jud. Comm.,

Violence Against Women: The Increase of Rape In America 1990,

102d Cong. 1 (1991).

Steinberg, Allen,

THE TRANSFORMATION OF CRIMINAL JUSTICE:

PHILADELPHIA 1800-1890 (1989) $28,29,141$ 
Stephen, James Fitzjames,

A History OF THE CRIMINAL LAW OF ENGLAND 245 (1883) .................................26

Tarr, G. Alan, UndERSTANDING STATE CONSTITUTIONS 198 (1998)

Tjaden, Patricia \& Nancy Thoennes,

Nat'l Inst. of Justice, U.S. Dep't of Justice,

Extent, Nature, and Consequences of Rape Victimization: Findings from

the National Violence Against Women Survey, 1 (2006), available at

https://www.ncjrs.gov/pdffiles1/nij/210346.pdf

U.S. Dep't of Justice, Federal Bureau of Investigation, 2016 Crime in the United States, Violent Crime, Rape

Utah Office on Domestic \& Sexual Violence,

No More Secrets: Utah's Domestic \& Sexual Violence Report 2013

(2013), available at https://justice.utah.gov/Violence/

Annual\%20Reports/nms_annualreport_2013.pdf

93, 94, 95

White, Jean Bickmore,

Charter for Statehood: THe Story of Utah's State

CONSTITUTION (1996)

White, Jean Bickmore,

The Utah State Constitution 113 (2011) 32 


\section{INTRODUCTION}

This petition is filed on behalf of four women who were sexually assaulted, and yet the public prosecutor with jurisdiction refused to file criminal charges against their attackers. The plight of these victims is hardly unique. In this country today, an intense debate is raging about how women who have been raped or sexually assaulted can make themselves believed by a criminal justice system that all too often seems ready to ignore their pleas.

Fortunately, here in Utah, a remedy is at hand. Utah Constitution, article VIII, § 16 , anticipates situations where a crime victim might need her own avenue for initiating criminal prosecution. Accordingly, this constitutional provision provides that "[i]f a public prosecutor fails or refuses to prosecute, the Supreme Court shall have power to appoint a prosecutor pro tempore." Id. Indeed, to underscore the fact that other ways to initiate a prosecution are available, the provision specifically states that public prosecutors in this state shall have the "primary responsibility" for prosecuting crimes. "Primary" responsibility is, of course, not the same as exclusive responsibility.

This petition presents a compelling case for this Court to use its power to appoint a prosecutor, both to bring justice for these four particular sexual assault victims and, more broadly, to help protect a class of victims - women and girls who have been sexually assaulted - who are under-protected by current prosecutorial practices in our country. This Court can address systemic under-prosecution of rape cases through its power under the Utah Constitution, not only under the Court-Appointed Prosecutor Provision, art. 
VIII, § 16, but also to protect rights contained in Utah's Victims' Rights Amendment, art.

I, $\S 28$, the Utah Uniform Operation of Laws Clause, art. I, § 24, and the Utah Equal

Rights Provision, art. IV, $\S 1$. It also has power to act through the federal Equal

Protection Clause, U.S. Const., amend. XIV.

Because the filing of serious criminal charges is plainly justified in each of these

four sexual assault cases, this Court should appoint a prosecutor to prosecute the sexual assaults committed against these women.

\section{THIS COURT POSSESSES ORIGINAL JURISDICTION OVER THE PETITION}

This Court has original jurisdiction over this petition for appointment of a prosecutor pro tempore (hereinafter referred to as a "court-appointed prosecutor") pursuant to Utah Const., art. VIII, $§ 16$ ("If a public prosecutor fails or refuses to prosecute, the Supreme Court shall have power to appoint a prosecutor pro tempore"). As this Court has explained: "This Court has original jurisdiction over certain matters, including petitions for extraordinary writs. In such situations, we do not conduct a review in our appellate capacity, but rather serve as the forum in which claims are initially heard." Mouty v. The Sandy City Recorder, 2005 UT 41, ๆ 10, 122 P.3d 521 (internal citation omitted). 


\section{RELEVANT CONSTITUTIONAL PROVISIONS}

This petition is filed under the Court-Appointed Prosecutor Provision of the Utah

Constitution. This provision appeared in the original 1896 Constitution, authorizing

district courts to appoint prosecutors:

[County attorneys. Election, term, etc.] A County Attorney shall be elected by the qualified voters of each county who shall hold his office for a term of two years. The powers and duties of County Attorneys, and such other attorneys for the State as the Legislature may provide, shall be prescribed by law. In all cases where the attorney for any county, or for the State, fails or refuses to attend and prosecute according to law, the court shall have power to appoint an attorney pro tempore.

Utah Constitution of 1896, art. VIII, § 10.

The provision was amended in 1984 by the Utah electorate, vesting the power to

appoint prosecutors in this Court. The provision currently provides:

[Public prosecutors.] The Legislature shall provide for a system of public prosecutors who shall have primary responsibility for the prosecution of criminal actions brought in the name of the State of Utah and shall perform such other duties as may be provided by statute. Public prosecutors shall be elected in a manner provided by statute, and shall be admitted to practice law in Utah. If a public prosecutor fails or refuses to prosecute, the Supreme Court shall have power to appoint a prosecutor pro tempore.

Utah Const., art. VIII, § 16.

In 1994, the Utah electorate added a Crime Victims' Rights Amendment to the

Constitution, promising victims rights to justice and due process throughout the criminal justice process:

Article I, Section 28. [Declaration of the rights of crime victims.] (1) To preserve and protect victims' rights to justice and due process, victims of crimes have these rights, as defined by law:

(a) To be treated with fairness, respect and dignity, and to be free from harassment and abuse throughout the criminal justice process. 
Utah Const., art. I, § 28.

Also relevant to this case is a provision from the original 1896 Constitution, the Uniform Operation of Laws Provision:

All laws of a general nature shall have uniform operation.

Utah Const., art. I, § 24.

Also relevant is another provision from the original 1896 Constitution protecting equal rights for women:

The rights of citizens of the State of Utah to hold office shall not be denied or abridged on account of sex. Both male and female citizens of this State shall enjoy equally all civil, political and religious rights and privileges.

Utah Const., art. IV, $\S 1$.

\section{THE JANE DOES ARE ENTITLED TO PROCEED BY WAY OF PSEUDONYM}

Because the specific names of the sexual assault victims - and their attackers - are not relevant to the issues presented by this petition, we refer to the victims pseudonymously as Jane Doe 1, Jane Doe 2, Jane Doe 3, and Jane Doe 4 - collectively "the Jane Does." The Jane Does are aware that, should the Court order a prosecution, the trial court may determine, at some stage of the proceedings, that their names should become a matter of public record. At this stage in the proceedings, however, the victims' specific identities should be protected. The Jane Does are simply seeking initiation of a criminal prosecution, at which point the case will travel through the criminal justice system in the district court in the ordinary manner. The initial determination by this 
Court of whether to initiate a prosecution does not require immediately and publicly disclosing the identities of these sexual assault victims (one of whom was sexually assaulted as a minor).

Utah's Victims' Rights Amendment promises crime victims that they will be "treated with fairness, respect, and dignity" and be "free from harassment and abuse throughout the criminal justice process." Utah Const., art. I, § 28(1)(a). Construing very similar language in the New Mexico Victims' Rights Amendment, New Mexico courts have instructed attorneys to "refrain from alluding to matters that are not reasonably relevant to the case at bar," such as crime victims' names. See State v. Fry, 2010 WL 4550716 (N.M. App. 2010). It is common practice for the courts of this state to use pseudonyms in sexual assault cases, particularly in cases (such as this one) where a juvenile is involved. See, e.g., M.J. v. Wisan, 2016 UT 13, ๆ 1, 371 P.3d 21 (using the pseudonym M.J.). The reason for such protection is that "[f]or most sexual assault victims, privacy is like oxygen; it is a pervasive, consistent need at every step of recovery." Ilene Seidman \& Susan Vickers, The Second Wave: An Agenda for the Next Thirty Years of Rape Law Reform, 38 SuffolK U. L. REV. 467, 473 (2005).

In civil cases, this Court has recognized the ability of a plaintiff to proceed under a pseudonym "where there is an important privacy interest" at stake. Gardner v. Board of County Comm 'rs of Wasatch County, 2008 UT 6, - 52, 178 P.3d 893. The federal courts with jurisdiction in Utah follow a similar approach. See, e.g., Lindsey v. Dayton-Hudson Corp., 592 F.2d 1118, 1125 (10th Cir. 1979). 
For all these reasons, the Jane Does file this petition pseudonymously. Should a separate motion to proceed by way of pseudonym be required, the Jane Does respectfully request that this petition be construed as a motion for leave to proceed by way of pseudonym or, alternatively, that they be granted leave to file a specific motion to proceed in this fashion. ${ }^{1}$

\section{FACTS RELEVANT TO THE PETITION}

This petition is brought by four women, who were all recently sexually assaulted. They all made timely reports to law enforcement authorities, who investigated and found the allegations appropriate to present to the Salt Lake District Attorney's Office for prosecution. Yet despite the seriousness of the crimes and the compelling evidence demonstrating victimization, the Office thereafter refused to prosecute. The facts surrounding each of the four crimes are set out in this section, following the traditional approach for evaluating criminal charging decisions of viewing the facts in the light most favorable to prosecution. See, e.g., State v. Schmidt, 2015 UT 65, ๆ 42, 356 P.3d 1204 (reversing magistrate judge's decision to refuse to bind over sex abuse case for prosecution because, in disregarding victim's testimony "the magistrate impermissibly weighed the evidence instead of viewing witnesses' testimony in the light most favorable to the prosecution"). The following brief factual summaries are supported by the materials indicated, including police reports and other materials contained in the appendix to this petition (“App.”). Further details are also contained in the supporting

\footnotetext{
${ }^{1}$ The Jane Does have also redacted the names of the perpetrators of the crimes against them, referring to them only as "Richard Roe" 1, 2, 3, and 4.
} 
materials. Should further proof of the facts be required by the Court, the Jane Does request an evidentiary hearing or such other procedure as the Court may direct to establish the prima facie validity of their assertions.

\section{The Rape of Jane Doe 1 and the Non-Prosecution of Her Rapist. A. The Rape of Jane Doe 1.}

On November 17, 2017, Richard Roe 1 came over to the home of Jane Doe 1. [App. at 3.] Both Roe and Doe were seventeen years old, and both were high school classmates. [App. at 3.] Jane Doe 1 has been diagnosed with Charcot-Marie-Tooth (CMT), which is a form of muscular dystrophy. [App. at 309.] According to her physical therapist, CMT affects the peripheral nervous system and is characterized by muscle atrophy, muscle weakness, and disturbances in peripheral sensation. [App. at 309.] Jane Doe 1 has undergone standardized testing and demonstrated considerable deficits in regard to strength, balance, and ability to perform coordinated tasks and activities requiring endurance. [App. at 309.] Functionally, she must act slowly and deliberately, including with her speech. [App. at 309.] What strength she does have diminishes rapidly during a sustained effort and she fatigues quickly. [App. at 309.] In order to walk, Doe relies on an imposing German Shepard assistance dog. [App. at 8.]

Roe was ostensibly at Doe's home to work on a school project. [App. at 3.] Roe was aware that Doe's mother had left the home and was taking Doe's assistance dog with her to a dog kennel. [App. at 315.] While both her trained dog and mother were away 
from the house, Roe suggested that the two watch a video related to the school project in the basement of Doe's home. [App. at 4.]

Roe assisted Doe down the stairs, where Roe had Doe alone and isolated in her home. Doe was not in a romantic relationship with Roe. [App. at 4.] Soon after beginning to watch the video on the couch, Roe forced a kiss on Doe. [App. at 4.] Roe then reached behind Doe and unclasped her bra. [App. at 4.] He rapidly pulled off her shirt. [App. at 9.] Roe further undressed Doe within a very short time. [App. at 9.] Roe was aggressive in the way he moved her, as well as pulled off her clothes. [App. at 9-10.] Doe became scared and froze. [App. at 9.] Further, because of her medical condition, she was afraid to say no; she worried if she said no, he would hurt her. [App. at 4, 10.] Roe knew of Doe's medical condition, and thus was in a position to know she would not or could not fight back. [App. at 9.] While Doe is physically disabled, Roe is a much larger, athletic young man. [App. at 4, 9.] Doe was scared by Roe's aggressiveness. [App. at 4, 9.] Doe knew Roe to be an aggressive person and was fearful as his demeanor changed and his gaze on her was unrecognizable. [App. at 4,9.]

Doe's body language communicated she was unwilling to participate. [App. at 9.] Her physical limitations made it impossible for her to resist Roe's advances. [App. at 9.] Doe did not have the protection of her dog nor her mother to yell out to, and she was frozen by her fear. [App. at 9.] Doe was shocked and scared and did not know what to do or say. [App. at 9-10.] 
Within a few seconds, Roe pulled off Doe's pants and underwear. [App. at 9.] She acted in a way that Doe felt he would understand that she didn't want to participate. [App. at 4, 9.]

Roe then aggressively performed oral sex on Doe. [App. at 9.] He also inserted his fingers in her vagina. [App. at 9,10.] Roe also grabbed Doe's head and forced her to perform oral sex. [App. at 9, 10.] Doe remained paralyzed by fear throughout the attack. [App. at 9.]

Roe also inserted his penis in Doe's vagina. [App. at 9.] Doe was afraid that if she said anything he would hurt her. [App. at 9.] The attack happened very rapidly. [App. at 9.] Doe's only participation through all of this was initially allowing Roe to kiss her for 10 seconds. [App. at 8-9.]

When the sexual attack ended, Roe told Doe not to tell anyone what had happened. [App. at 10.] Later that day, Doe called a close friend and was very upset. Doe told the friend that she had not told Roe no because he was being aggressive and thought he would hurt her. [App. at 16.] Doe was not herself in the following days and disclosed the attack to her mother about one week later. [App. at 9, 10.] Roe declined an interview with police. [App. at 13.]

\section{B. The Rape of Jane Doe 1 Is a Felony Crime Under the Utah Criminal Code.}

The Utah Criminal Code defines a first-degree felony crime of rape in Utah Code

$\S 76-5-402$. An actor commits the crime of rape when he "has sexual intercourse with another person without the victim's consent." Utah Code § 76-5-402(1). Utah Code 
also provides that an act of sexual intercourse is "without the consent of the victim" in any of the following circumstances: "the actor overcomes the victim through actual application of physical force or violence" or "the victim has not consented, and the actor knows the victim is ... physically unable to resist." Utah Code $\S 76-5-406(2) \&(5)$.

An actor commits the crime of object rape when he "causes the penetration, however slight, of the genital or anal opening of another person who is 14 years of age or older, by any foreign object, substance, instrument, or device, including a part of the human body other than the mouth or genitals, with intent to cause substantial emotional or bodily pain to the victim or with the intent to arouse or gratify the sexual desire of any person." Utah Code $\S 76-5-402.2$.

The evidence described above, if believed by the jury, would clearly prove the crimes of rape and object rape.

\section{The Public Prosecutor Has Refused to Prosecute the Crimes Committed Against Jane Doe 1.}

On February 23, 2018, a Deputy District Attorney in the Salt Lake District Attorney's Office sent an email to Jane Doe 1's attorney. The letter states: "I have decided that I will NOT file a charge against the suspect." [App. at 314 (emphasis in original).] The prosecutor explained that he believed Jane Doe 1 but did not think that a jury was likely to convict Roe. [App. at 314.] On March 1, 2018, the prosecutor sent a formal letter to the Sandy City Police Department declining the case. [App. at 321.]

Following a request from Jane Doe 1 to the Utah Attorney General's Office that it prosecute the case, on April 10, 2018, the Office declined to do so in light of the "high 
degree of deference" that it affords local prosecutors. [App. at 323.] A further meeting with the District Attorney's Office was also unproductive in securing prosecution.

\section{The Rapes of Jane Doe 2 and the Non-Prosecution of Her Rapist. A. The Rapes of Jane Doe 2.}

Jane Doe 2 is a 38 -year-old woman suffering from cerebral palsy, a condition generally marked by impaired muscle coordination (spastic paralysis) and/or other disabilities, typically caused by damage to the brain before or at birth. [App. at 22, 74.] Before being sexually assaulted, Doe had limited knowledge of what sexual intercourse was in general. [App. at 36, 40.]

On May 9, 2016, Doe was walking to an appointment when she was approached by Richard Roe 2, a convicted rapist. [App. at 22.] Roe recognized Doe from her previous employment, but Doe didn't recall ever meeting him before. [App. at 22.] Roe continued walking with Doe to the health center, where they exchanged numbers and Doe passingly stated which apartment she lived in. [App. at 22, 26.] Roe waited outside for Doe to finish her appointment before they ate lunch together. Roe then took Doe back to his residence by bus. [App. at 22.]

After going inside of Roe's home, Roe ordered Doe to remove her clothing. Doe felt that she didn't have a choice and complied. [App. at 22, 26.] Roe removed his own clothing and then inserted his tongue into Doe's vagina. [App. at 22.] Roe then inserted an unknown number of fingers into Doe's vagina. [App. at 22.] Doe cried out in pain and repeatedly begged for Roe to stop, but he continued. [App. at 22-23, 72.] After 
finishing assaulting Doe, Roe finally allowed Doe to get dressed. [App. at 23.] $\mathrm{He}$ followed her onto the bus and stayed next to her until she got off at her home stop. [App. at $23,27$.$] Doe was afraid to call the police because Roe knew where she lived, and she$ wasn't sure exactly what happened to her. [App. at 27.] Doe's husband later reported that Doe seemed depressed but refused to talk about why. [App. at 29.]

For two to three days after the initial assault, Doe noticed that Roe had left her multiple voicemails. On one of these mornings, Doe left her apartment at the same time as usual, when she noticed that Roe had been unknowingly waiting for her outside of her complex. [App. at 23.] Roe brought Doe to lunch, where he told her that he was a sex offender and threatened that "if she left, he would do something worse than what he had done." [App. at 27.] Roe then led Doe back to his residence. [App. at 23.]

Once at Roe's residence, Roe played pornographic videos for Doe to watch so he could explain to her what intercourse was. [App. at 36.] Then, Roe ordered Doe to remove her clothing and she again complied out of fear. [App. at 38, 72.] Roe orally and digitally penetrated Doe's vagina, causing pain. [App. at 23.] Doe asked him to stop and Roe climbed on top of Doe's naked body, then forced his penis into Doe's vagina. [App. at 23.] Doe repeatedly protested and told him that he was hurting her, and Roe responded that she must be "tight" if she was saying that it hurt. He continued the assault. [App. at 23.] Doe remembered Roe talking about an orgasm a couple of times but wasn't sure what it meant, so she was not able to confirm whether Roe ejaculated inside of her. [App. at 23.] 
Roe didn't finish assaulting Doe until nighttime, after the busses were no longer running. [App. at 28.] Doe felt that she could not leave because Roe was situated in between her and the front door, he had access to her cellphone, and had even blocked the entrance to the bathroom with a fan. [App. at 23, 28, 38.] At some point in the night, Doe attempted to text her husband for help, but Roe caught her and became angry. [App. at 23.] He told her that he deleted the text messages and then yelled at her, lecturing that her husband was going to call the police. [App. at 23, 28.] This outburst stopped any more sexual assaults against Doe for the night, but Roe kept her in the apartment. [App. at 28.]

The next day, Roe again forced Doe to allow oral penetration of her vagina. [App. at 23.] Roe then commanded Doe to position herself on her hands and knee. Roe proceeded to forcefully and repeatedly penetrate Doe's anus and vagina with his penis. [App. at 23, 37, 72.] Doe continuously cried out in pain and begged Roe to stop. [App. at 23.] At some point during this assault, Roe told Doe that he couldn't stop because "people were spying on them." [App. at 23.] He opened the front door and stood naked in the doorway, "as if looking for people." [App. at 23.] After this brief break, Roe continued anally raping Doe against her protests. [App. at 23.]

When Roe was finished, he applied lotion to Doe's naked body. He then steered Doe to the shower in the bathroom. Using the detachable shower head, Roe sprayed water inside of Doe's vagina and anus, and Doe watched blood rinse down the shower drain. 
[App. at 23, 72.] Roe then guided Doe back to the mattress, where he fell asleep with his arm again tightly wrapped around her. [App. at 23.]

The next morning, Doe quietly dressed herself and gathered her belongings in an attempt to leave without awaking Roe. [App. at 23.] As she opened the front door, Roe pulled her back inside. [App. at 23.] He dumped her purse and bookbag and searched through the items. [App. at 23.] After calling Doe a "retard," he allowed her to leave his residence. [App. at 28.]

Doe reported the assaults to police on May 15, 2016. [App. at 22.] She was interviewed by an officer and then transported to the hospital where a SANE nurse conducted a physical examination of her abrasions and collected rape kit evidence. [App. at 24, 70-80.]

Roe was interviewed multiple times throughout the investigation, where he gave a series of conflicting and evasive stories. [App. at 3-35, 41-43, 62.] Roe admitted that he knew that Doe was a virgin and had extensive mobility problems. [App. at 33-34.] He repeatedly denied that any actual penetration of Doe ever happened. [App. at 42, 62.] But the results from the DNA found inside Doe's vagina matched Roe. [App. at 42, 63, 66. $]^{2}$

2 Because Roe was a convicted sex offender, his DNA was available for comparison. A later buccal swab, obtained via search warrant, confirmed the match. [App. at 46, 48.] 


\section{B. The Rapes of Jane Doe 2 Are Felony Crimes Under the Utah Criminal Code.}

As discussed above in connection with Jane Doe 1, the Utah Criminal Code defines a first-degree felony crime of rape in Utah Code $\S 76-5-402$. An actor commits the crime of rape when he "has sexual intercourse with another person without the victim's consent." Utah Code $\S 76-5-402(1)$. The Utah Criminal Code also defines a first-degree felony crime of object rape, which includes penetration of the genitals with fingers. Utah Code $\S 76-5-402.2$. Roe's actions described above violated these criminal statutes.

\section{The Public Prosecutor Has Refused to Prosecute the Rapes Committed Against Jane Doe 2.}

The District Attorney of Salt Lake City declined to file charges, citing an alleged lack of evidence. [App. at 45, 49, 50.]

\section{The Rape of Jane Doe 3 and the Non-Prosecution of Her Rapist.}

\section{A. The Attacks on Jane Doe 3.}

Richard Roe 3 is a prominent law enforcement officer in Utah County who is more than 50-years-old. In January 2015, Roe instituted a new Citizen's Advisory Board. Jane Doe 3, a 24-year-old student at Utah Valley University at the time, was interested in the Board's activities. She hoped to conduct research regarding the use of body-worn cameras and a simulator for officer-involved shootings. [App. at 89, 103, 113.] One of Doe's professors arranged for her to become involved with the Board and to work with Roe while doing so. Roe and Doe started working together. [App. at 89, 103.] Soon 
thereafter, Roe started acting in a sexually aggressive manner toward Doe. [App. at 89, 90, 103.]

At the end of October 2016, Doe sent Roe a text. She wrote that although she wanted to learn more about police work, she wanted to set clear professional boundaries and did not want to have a romantic or sexual relationship with Roe. [App. at 90.]

Not long after this exchange, the two were at Roe's house, where Roe repeatedly attempted to kiss Doe, but she rebuffed his advances. During the same encounter, Roe placed his hand on Doe's leg. She pushed his hand away twice before Roe stated something to the effect of "I'll decide" and moved his hand higher up on her leg. [App. at $107,113$.$] On a separate occasion, after Doe had rebuffed his advances, Roe stood up,$ placed his hand on his gun and said in a threatening manner, "I am going to go put this away.” [App. at 92.]

Doe definitively stated (again) that she wanted to learn about police work but was not interested in a romantic relationship with Roe. Concerned about what to do, Doe discussed Roe's behavior with her professor. [App. at 90.] Her professor advised her to set clear professional boundaries and avoid being alone with Roe. [App. at 90.]

Roe later asked Doe to attend a dinner with other members of the board and a friend of Roe under the guise that the dinner was related to their work. [App. at 91.] Upon arrival, Doe realized that the dinner was a social gathering and did not involve her work on the Board. During dinner Roe continually placed his hand on Doe's leg in a sexual manner. [App. at 91, 114.] After dinner Roe called Doe. During this 
conversation, Roe stated, "thank you for letting me put my hand on your leg and thank you for liking it." [App. at 91.] Over the coming weeks, Roe's sexual advances became more aggressive as Doe continued to feel threatened, trapped, and unable to dissuade Roe's advances. [App. at 93, 114.]

In January 2017, Roe raped Doe on two separate occasions, four different times. [App. at 93-97, 115.] On at least one of those occasions, Doe repeatedly and audibly said "no" as Roe forced himself on her, she clutched her pants to avoid having them removed, and only succumbed after Roe slammed his shoulder into her chest and overpowered her physically. [App. at 93, 115.] Doe reported these instances to at least three different individuals at the time they happened or shortly thereafter. [See, e.g., App. at 99, 106, 113-16.]

None of Doe's sexual encounters with Roe was consensual. She resisted his suggestive comments, his groping and fondling, and his assaults, but did not know what kind of response she would trigger if she tried to forcibly reject his advances. [App. at 93, 114.] She knew he had a gun and that he had specifically talked to her about his gun, she knew he had refused to remove his hands when requested to do so, and she knew that he had the final say in the Department. [App. at 93, 114.] Her fear of reporting Roe's sexual assaults to the Department where Roe worked was clear. [App. at 93, 114-15.]

Shortly after the last time Roe raped Doe, Roe left on vacation. Doe took the opportunity to go to the police and report the attacks. [App. at 94, 97-98.] 


\section{B. The Attacks on Jane Doe 3 Are Felony Crimes Under the Utah Criminal Code.}

As discussed above in connection with the other Jane Does, the Utah Criminal Code defines a first-degree felony crime of rape in Utah Code $\S 76-5-402$. The Utah Criminal Code also defines a crime of Forcible Sex Abuse, committed when "under circumstances not amounting to rape, object rape, sodomy, or attempted rape or sodomy, the actor touches the anus, buttocks, pubic area, or any part of the genitals of another, or touches the breast of a female, or otherwise takes indecent liberties with another, with intent to cause substantial emotional or bodily pain to any individual or with the intent to arouse or gratify the sexual desire of any individual, without the consent of the other, regardless of the sex of any participant." Utah Code $\S 76-5-404(1)$. As used in this section, taking "indecent liberties" includes "touching the actor's genitals . . . against any part of the body of the victim" or "simulating or pretending to engage in sexual intercourse with the victim." Utah Code $§ 76-5-416(1) \&(3)$.

The evidence described above in the case of Jane Doe 3 would, if believed by a jury, prove multiple crimes of Rape and Forcible Sex Abuse.

\section{The Public Prosecutor Has Refused to Prosecute the Rapes Committed Against Jane Doe 3.}

Because Roe was a very prominent member of law enforcement in Utah County, consideration of the prosecution of Roe was moved to the adjoining county of Salt Lake. This case was screened in person with a senior Deputy District Attorney in the Salt Lake District Attorney's Office, who declined to prosecute based on alleged "evidence 
problems." [App. at 117.] A subsequent meeting with the Office proved futile in getting charges filed.

\section{The Sexual Assault of Jane Doe 4 and the Non-Prosecution of Her Molester.}

\section{A. The Sexual Assault of Jane Doe 4 .}

On February 18, 2017, Jane Doe 4 received a massage from Richard Roe 4 at a licensed and established massage and spa business. This was Doe's second massage from Roe, with the first massage being very professional. [App. at 121, 133.]

During the second massage, Roe asked Doe if she had any problem areas, and she mentioned her hips. [App. at 133.] He started massaging her back, lower back, glutes, hips, shoulders, and neck using both hands. He told her that he obviously couldn't see well from a certain angle and instructed her to tell him if he got too close. [App. at 122, 133.] While Doe was lying on her stomach, Roe moved around the area where Doe's leg connected to her body and touched the outside of her labia briefly a couple of times, then quickly moved to her other side and worked on her right leg. [App. at 134.] Roe asked repeatedly if things were tender and Doe always answered yes. As he worked on her glute and upper thigh area he asked if it was too close and she said no. [App. at 134.] Right after that he put a lot of pressure on her glute and then inserted two fingers into her anus. [App. at 123-24, 134.] Doe was not immediately sure what was happening and if it was just the pressure of the massage that made her feel like something was in her anus. [App. at 124.] She told Roe that that was too close, and he apologized and kept his distance. [App. at 124.] A minute later he asked her to roll onto her back. [App. at 124.] Roe 
started massaging Doe's legs and moved toward her inner thighs. [App. at 134.] Roe's fingers touched Doe's labia again, multiple times, and came closer each time. [App. at 125, 134.] She told him that was too close, and he apologized again. [App. at 125.] He had her bend her left leg and brought it to the side and opened her leg. [App. at 134.] Roe asked if that was tender and Doe said yes. [App. at 126, 134.] Roe then pressed on the front area with one hand, pulled her left glute down and away. Doe felt that he was touching or partially inserting his thumb into her vagina. [App. at 126.] She said "ow, that hurts," and he apologized and said a certain muscle was really locked up. [App. at 126.] He stopped what he had been doing, lightly massaged her outer hip, and then recommended stretches she could do daily. [App. at 127.] Doe got dressed and then left. [App. at 127.]

Two days later, on February 20, 2017, Doe reported the incident to the Salt Lake Police Department. [App. at 133.] Officer Taryn Culverwell asked Doe if she sustained any injuries and Doe reported a burning sensation in her rectum and believed it was a direct result of Roe placing his fingers in her anus. [App. at 135.] The officer recommended that Doe be examined by a Sexual Assault Nurse Examiner (SANE), which was completed at LDS Hospital. [App. at 197-204.] SANE nurse Baldwin (of Wasatch Forensic Nurses) noted a laceration in Doe's anus. [App. at 135, 151, 203.] In an interview with Detective Mott on February 24, 2017, Doe reported that during her first massage with Roe she felt that he was pushing against her arms with his private parts. [App. at 151.] During the second massage she again felt like he was 
pushing his private parts into her arm and she knew it was not an accident. [App. at 151.] She remembered freezing and wondering if it was really happening. [App. at 151.] Doe also remembered Roe's penis rubbing against her and that it was partially erect. [App. at 151.]

\section{B. The Sexual Assault Against Jane Doe 4 Is a Felony Crime Under the Utah Criminal Code.}

The Utah Criminal Code defines a first-degree felony crime of object rape in Utah Code $\S 76-5-402.2$. An actor commits the crime of object rape when he "causes the penetration, however slight, of the genital or anal opening of another person who is 14 years of age or older, by any foreign object, substance, instrument, or device, including a part of the human body other than the mouth or genitals, with intent to cause substantial emotional or bodily pain to the victim or with the intent to arouse or gratify the sexual desire of any person.”

The evidence described above, if believed by the jury, would prove that Richard Roe 4 committed the first-degree felony crime of object rape against Jane Doe 4. (Roe also committed other lesser included sexual offenses as well.)

\section{The Public Prosecutor Has Refused to Prosecute the Sexual Assault Against Jane Doe 4.}

Detective Jeff Mott of the Special Victims Unit of the Salt Lake City Police Department presented the case to the Salt Lake District Attorney's Office, recommending prosecution. On April 17, 2017, a Deputy District Attorney in the Office sent a declination letter, declining to file charges due to alleged "insufficient evidence." [App. 
at 189.] Detective Motts then contacted the prosecutor and told him he didn't agree with that assessment. The Detective screened the case again with the prosecutor's supervisor, a senior Deputy District Attorney. That supervisor later wrote Detective Mott an email stating the case would be declined for unlikely success for prosecution. [App. at 187.]

Detective Mott then reached out to a SANE nurse, Beth Weekly, to set up an additional screening for May 4, 2017. In this screening meeting, Ms. Weekly explained the significance of Doe's anal tear, but the case was declined again. Detective Mott set up a final screening on May 16, 2017, attended by prosecutors and Detective Mott; Jane Doe 4; Salt Lake Police Sergeant Christansen; victim advocate Alex Merritt; and Doe's attorney, Bethany Warr. After the parties discussed the case, the District Attorney's Office again declined to file charges. At that point, Doe attempted to secure the filing of charges by the Attorney General's Office but was unsuccessful.

\section{ARGUMENT}

The Court should appoint a prosecutor to prosecute the sexual offenses committed against Jane Doe 1, Jane Doe 2, Jane Doe 3, and Jane Doe 4 by exercising its undoubted power under Utah Const., art. VIII, $\S 16$ - the Court-Appointed Prosecutor Provision. This provision authorizes this Court to appoint a prosecutor where a public prosecutor "fails or refuses to prosecute." Because prosecutors have failed and refused to prosecute the violent crimes committed against the Jane Does, this Court has the power to act.

This Court should act. Appointment of a prosecutor to pursue these well-founded cases would serve the interests of justice. Not only would it help to secure justice for 
these four victims and enforce this State's criminal laws against sexual violence, but it would also help to respond to the problem of under-prosecution of violent sexual crimes against women and girls, thus securing state constitutional rights under the Utah Victims' Rights Amendment, art. I, § 28; the Uniform Operation of Laws Clause, art. I, § 24; and the Equal Rights Provision, art. IV, $\S 1$. An appointment is also necessary to protect federal constitutional rights under the Equal Protection Clause. Accordingly, the Court should rule that appointment of a prosecutor is appropriate and direct briefing as to whom that prosecutor should be.

\section{The Court Should First to Determine the Meaning of the Relevant Utah Constitutional Provisions Without Reference to Federal Law.}

Before turning to the specifics of the Court-Appointed Prosecutor Provision, it is useful to set out the methodology for the proper interpretation of a provision of the Utah Constitution. This petition seeks judicial appointment of a prosecutor, raising both state and federal constitutional claims. This Court should prioritize consideration of the Utah Constitutional claims, turning to them first. See generally Robert F. WiLLIAMS, The LAW OF AMERICAN STATE CONSTITUTIONS 231-32 (2010) (arguing for a "New Judicial Federalism").

The key constitutional provision at issue in this petition is Utah's Court-Appointed Prosecutor Provision. This is a unique provision, drafted in response to the Utah Territory's unique experience of under-prosecution. The provision uses language that does not appear anywhere in the federal constitution. This Court has emphasized that 
"the standards for state and federal constitutional claims are [often] different because they are based on different constitutional language." Jensen ex rel. Jensen v. Cunningham, 2011 UT 17, ๆ 45, 250 P.3d 465.

In evaluating which order to proceed, Judge Sutton has recently provided useful insight in his book on state constitutional law. He suggests that state courts prioritize state constitutional claims, explaining that "[a] state-first approach to litigation over constitutional rights honors the original design of the state and federal constitutions." JefFrey S. SutTon, FifTy-One ImPerfect SOlutions: StATES AND the MAKING OF American Constitutional Law 179 (2018). Cf. West v. Thomson Newspapers, 872 P.2d 999, 1006-07 (Utah 1994) (calling for a "primacy model" to interpreting Utah's constitution). State constitutional law issues predominate in this petition and accordingly this Court should turn to them initially.

Generally, this Court has handled state constitutional law issues by seeking to determine the original meaning of Utah Constitutional provisions. Under this approach, the natural starting point for state constitutional interpretation is the text, as " $[\mathrm{t}] \mathrm{he}$ language of our constitution contains the surest indication of the intent of its framers and the citizens of Utah who voted it into effect." Am. Bush v. City of S. Salt Lake, 2006 UT 40, ๆ 16, 140 P.3d 1235. Words in the Utah constitution "must be taken to mean what they meant to the minds of the voters of the state when the provision was adopted." Tintic Standard Mining Co. v. Utah Cty., 80 Utah 491, 15 P.2d 633, 637 (1932); see also Richardson v. Treasure Hill Mining Co., 23 Utah 366, 65 P. 74, 81 (Utah 1901) 
(examining "[the framers'] discussions upon this subject[ ] [i]n the official report of the proceedings of the constitutional convention"); Ritchie v. Richards, 14 Utah 345, 47 P. 670, 679 (1896) (per Batch, J.) (adopting interpretation that was "in harmony with public thought and expression respecting the [issue in question] at the time of and before the holding of the constitutional convention"); State v. Elliott, 13 Utah 200, 44 P. 248, 251 (1896) (discerning the intent "of the framers of our fundamental law" in determining the scope of article VIII, section 4)). See generally Jeremy M. Christiansen, Some Thoughts on Utah Originalism: A Response, 2014 Utah L. ReV. ON LAW 1, 5-6 \& nn.26-36, 9-10 \& nn.59-64 (concluding that the prevailing approach to interpreting Utah's Constitution has been originalist). ${ }^{3}$

Of course, the text of a provision is not examined in isolation. This Court has made clear that "[c]onstitutional language must be viewed in context, meaning that its history and purpose must be considered in determining its meaning." Am. Bush, 2006 UT 40, $\mid 24$ (quoting Laney, 2002 UT 79, \ 37, 57 P.3d 1007). This Court "has a very long history of interpreting constitutional provisions in light of their historical background and

${ }^{3}$ Some of the older decisions of this Court have called for a consideration of "policy arguments in the form of economic and sociological materials to assist [the Court] in arriving at a proper interpretation of the [state constitution] provision in question." Society of Separationists, Inc. v. Whitehead, 870 P.2d 916, 921 n.6 (Utah 1993). More recent decisions cast doubt on that approach, with several Justices of this Court calling for repudiating Whitehead's policy-oriented approach. See, e.g., State v. Houston, 2015 UT 40, 154, 353 P.3d 55 (Lee, J., concurring in part and concurring in the judgment); Am. Bush v. City of S. Salt Lake, 2006 UT 40, ๆ 86, 140 P.3d 1235 (Durrant, J., concurring). Happily, this case presents no need to resolve these possibly conflicting views, as both originalist and policy-oriented interpretations of the Court-Appointed Prosecutor Provision lead to the same conclusion. Compare Part II, infra (discussing original meaning of the provision) with Part $\mathrm{V}$, infra (explaining public policy arguments regarding the provision). 
the then-contemporary understanding of what they were to accomplish." In re Young, 1999 UT 6, \ 15 \& n.5, 976 P.2d 581.

Finally, this Court had explained that it is reluctant to wade into "important [state] constitutional waters" without "in depth" briefing. Zimmerman v. Univ. of Utah, 2018 UT 1, ๆ 23, 417 P.3d 78. Accordingly, “in depth” briefing follows.

\section{Article VIII, Section 16 of the Utah Constitution Reflects a Long-Standing Tradition of Victim-Initiated Prosecution in America.}

Utah Constitution, article VIII, section 16 - and particularly the sentence we will refer to as Utah's Court-Appointed Prosecutor Provision - reflects a long-standing tradition of victim-initiated prosecution in this country, which remains particularly salient for victims of sexual assault crimes in Utah today.

\section{A. America's Criminal Justice System Initially Relied on a System of Victim-Initiated Prosecution.}

At the time of the drafting of the federal constitution and continuing throughout the nineteenth century, victim-initiated prosecutions were a significant way in which criminal charges were pursued. Under this system, victims directed their own criminal prosecutions - a fact later reflected in Utah's Court-Appointed Prosecutor Provision.

Victim-initiated prosecution rests on the principle that a crime harms not only the state but also the victim. Blackstone articulated this general view in his Commentaries on the Law of England: "In all cases the crime includes an injury: every public offense is also a private wrong, and somewhat more; it affects the individual, and it likewise affects the community." WILliam BLACKSTONE, COMMENTARIES ON THE LAWS OF ENGLAND, 
Vol. IV, Ch. 1, p. 5 (Dawsons of Pall Mall, London 1767). Relying on this fact as a spur to effective prosecution, the English tradition long recognized private criminal actions. As Sir James Stephen explained: "The fact that the private vengeance of the person wronged by a crime was the principal source to which men trusted for the administration of justice in early times is one of the most characteristic circumstances connected with English criminal law ....” JAMES FitZJAMES STEPHEN, A History OF THE CRIMINAL LAw of England 245 (1883); see also John H. Langbein, The Criminal Trial Before the Lawyers, 45 U. CHI. L. REV. 263, 311-12 (1978).

The English conception of victim-initiated prosecutions crossed the Atlantic to the American colonies. Histories concerning eighteenth century criminal justice in the United States - including the period before, during, and after the framing of the Constitution reveal that victims frequently brought and prosecuted criminal cases. At our nation's founding "private persons regularly prosecuted criminal cases." Steel Co. v. Citizens for a Better Environment, 523 U.S. 83, 127-28 (1998) (Stevens, J., concurring in the judgment). This victim-initiated prosecution is often referred to as "private prosecution," although this nomenclature may be a bit misleading. The prosecutions were often brought in the name of the State, such that the action was formally a criminal prosecution of the type that exists today. But "many criminal trials were in reality contests between subjects rather than contests between government and subject." William E. Nelson, Emerging Notions of Modern Criminal Law in the Revolutionary Era: An Historical 
Perspective, 42 N.Y.U. L. REV. 450, 468 (1967). As one scholar has described the

Colonial system:

At that time the victim was a key decision-maker in the criminal justice system as well as a direct beneficiary of it. He served as policeman and prosecutor who, if he chose to apprehend an offender and initiate a prosecution, did so directly and at his own expense. He did not have to rely on other government agencies. On the contrary he could not rely on them even if he had wanted to because they either did not exist or did not perform the function he sought. ...

While criminal prosecutions were brought in the name of the state, they were, in effect, private prosecution in which the state typically did not play an active role and did not have a vested interest. Crime was conceived of primarily as an injury to the individual victim, not an attack against the state or society.

William F. McDonald, Towards a Bicentennial Revolution in Criminal Justice: The

Return of the Victim, 13 AM. CRIM. L. REV. 649, 649-50 (1976).

This form of victim-initiated "prosecution dominated criminal justice during the colonial period," Allen Steinberg, From Private Prosecution to Plea Bargaining:

Criminal Prosecution, the District Attorney, and American Legal History, 30 CRIME \& DELINQ. 568, 571 (1984), and continued to be "a significant element of the criminal justice system through the nineteenth century.” Robert M. Ireland, Privately Funded Prosecutors in the Nineteenth Century United States, 39 Am. J. Legal Hist. 43, 43

(1995). As the Supreme Court recently explained in Rehberg v. Paulk, 566 U.S. 356

(2012), during the nineteenth century "it was common for criminal cases to be prosecuted by private parties." Id. at 364; see also Stewart v. Sonneborn, 98 U.S. 187, 198 (1879) (Bradley, J., dissenting) ("[E]very man in the community, if he has probable cause for prosecuting another, has a perfect right, by law, to institute such prosecution, subject 
only, in the case of private prosecutions, to the penalty of paying the costs if he fails in his suit").

Perhaps the most detailed study of private prosecution in the United States - a book-length historical review of nineteenth century prosecution in Philadelphia - reveals that direct victim prosecution for some types of crime continued late into the nineteenth century in one of the most urban and developed parts of the United States, Philadelphia. See Allen Steinberg, The Transformation of Criminal Justice: Philadelphia 1800-1890 (1989). Based on a thorough examination of court records, Steinberg reports that "[d]uring the first half of the nineteenth century, private prosecution dominated criminal justice in Philadelphia.... [M] ost criminal prosecutions were initiated by private citizens." Id. at 38. Observers remarked on the "spirit of litigation" that pervaded this use of the courts for a wide range of complaints. Id. Citizens from all walks of life and in all economic circumstances initiated criminal prosecutions. See id. Of particular relevance to this case, private prosecutions were particularly useful for relatively disempowered groups, such as women who were victims of domestic violence. See id. at 69-71 (noting how women used private prosecutions in Philadelphia to protect against sexual violence and domestic abuse); see also Edwin Surrency, The Evolution of an Urban Judicial System: The Philadelphia Story, 1683-1968, 18 AM. J. Legal Hist. 95 (1974).

The Philadelphia story is typical of the experience in other states, where victimdriven prosecution was also widely used. See, e.g., Richard Gasjins, Changes to the 
Criminal Law in Eighteenth Century Connecticut, 25 AM. J. Legal Hist. 309 (1981);

Michael S. Hindus, The Contours of Crime and Justice in Massachusetts and South

Carolina, 1767-1878, 21 AM. J. LegaL. Hist. 212 (1977); William H. Lloyd, Jr., The

Courts of Pennsylvania in the Eighteenth Century Prior to the Revolution, 56 U. PA. L.

REV. 28 (1908); William Nelson, Emerging Notions of Modern Criminal Law in the

Revolutionary Era: An Historical Perspective, 42 N.Y.U. L. REV. 450 (1967); Donna J.

Spindel, The Administration of Justice in North Carolina, 1720-1740, 25 AM. J. LEGAL

Hist. 141, 145 (1981); Mike McConville \& Chester Mirsky, The Rise of Guilty Pleas:

New York, 1800-1865, 22 J.L. \& SoC'Y 443, 448-59 (1995) (explaining how New York

City private prosecutors or complainants initiated indictments during the first half of the nineteenth century and often conducted trials). ${ }^{4}$ Thus, one key observer of America in the first half of the nineteenth century, Alexis de Tocqueville, recognized that at the time "the officers of the public prosecutor's office are few, and the initiative in prosecutions is not always theirs." AleXis De ToCQUeVILle, Democracy IN AMERICA, 96 (J.P. Mayer ed. 1969). ${ }^{5}$

${ }^{4}$ Recently, Professors Woolhandler and Nelson have been cited by a justice on this court for the proposition that "[e]arly American courts uniformly proscribed the private prosecution of criminal actions." Gregory v. Shurtleff, 2013 UT 18, \ 76, 299 P.3d 1098, 1123 (Lee, J., concurring and dissenting) (citing Ann Woolhandler \& Caleb Nelson, Does History Defeat Standing Doctrine?, 102 MicH. L. REV. 689, 696 (2004)). To the extent that the point was being made that criminal prosecutions must be brought in the name of the State, the point is entirely accurate. Indeed, as originally drafted, Utah Const., art. VIII, $\S 18$ provided that "[t] he style of all process shall be, 'The State of Utah,' and all prosecutions shall be conducted in the name and by the authority of the same." (This provision was repealed in 1984.) But if a broader point is being suggested that private citizens could not initiate a prosecution in the early days of this country, Woolhandler and Nelson are clearly incorrect.

${ }^{5}$ Although this case focuses on state constitutional law, it may also be relevant to note 
This historical research demonstrates that victim-initiated prosecutions were widely available in this country during the nineteenth century.

\section{B. The Utah Constitutional Convention Specifically Drafted Article VIII, Section 16 to Preserve Victim-Initiated Prosecutions in Utah.}

Against this backdrop of a well-established tradition of victim-initiated

prosecution in this country, it is unsurprising to find that this form of prosecution is specifically enshrined in Utah's Constitution - in the Court-Appointed Prosecutor Provision.

Before turning to the specifics of the provision, some history about Utah's Constitutional Convention may usefully set the stage. The Convention began on March 4, 1895 and continued for a little over two months. See generally JeAn BiCKMORE White, Charter for Statehood: The Story of Utah's State Constitution (1996). The Convention's goal was to draft a state constitution that would "prove acceptable to Congress.” Brad C. Smith, Comment, Be No More Children: An Analysis of Article I,

that victim-initiated prosecutions existed (albeit in more limited form) in the early federal system. An early opinion by Attorney General Bradford indicates that the colonial practice continued at least for a brief period under the Constitution. Bradford considered a request by a British consul for prosecution of a crowd that had harassed him in 1794 after the district attorney had declined to prosecute. While agreeing with the district attorney that federal prosecution was not warranted, the Attorney General opined that:

[I]f the party injured is advised or believes that the federal courts are competent to sustain the prosecution, I conceive he ought not to be concluded by my opinion or that of the district attorney. If he desire it, he ought to have access to the grand jury with his witnesses; and if the grand jury will take it upon themselves to present the offense in that court, it will be the duty of the district attorney to reduce the presented into form, and the point in controversy will thus be put in train for judicial determination.

1 Op. Att'y Gen. 43 (1794) (emphases omitted). 
Section 4 of the Utah Constitution, 1992 UTAH L. REV. 1431, 1454. As a result, the delegates at the Convention often "'borrowed heavily from earlier Utah constitutions and other state constitutions."” Paul G. Cassell, The Mysterious Creation of Search and Seizure Exclusionary Rules Under State Constitutions: The Utah Example, 1993 UTAH L. REV. 751, 800 (quoting John J. Flynn, Federalism and Viable State Government-The History of Utah's Constitution, 1986 UTAH L. REV. 319, 323).

Victim-initiated prosecution was protected in the Article addressing Utah's Judicial Department - e.g., Article VIII. Other provisions in Article VIII were "designed to fit the pattern common to other state court systems at the time." JEAN Bickmore White, The Utah State Constitution 113 (2011). The Article contained twenty-eight detailed sections, including detailed sections regarding the jurisdiction of the Supreme Court (§ 4) and district courts (§ 7), the definition of judicial districts (§ 16), and a requirement that Supreme Court decisions be in writing $(\S 25)$ and with a syllabus $(\S 26)$.

Article VIII also contained a provision providing for the election of County Attorneys, while preserving victim-initiated prosecution in its last sentence - the CourtAppointed Prosecutor Provision:

Sec. 10. [County attorneys. Election, term, etc.] A County Attorney shall be elected by the qualified voters of each county who shall hold his office for a term of two years. The powers and duties of County Attorneys, and such other attorneys for the State as the Legislature may provide, shall be prescribed by law. In all cases where the attorney for any county, or for the State, fails or refuses to attend and prosecute according to law, the court shall have power to appoint an attorney pro tempore. 
Utah Constitution of 1896, art. VIII, $\S 10$ (emphasis added) (currently found in art. VIII, $\S 16$, as discussed below) ${ }^{6}$

Given that many other provisions in the Utah Constitution were simply copied from other Constitutions, the question arises as to where the Court-Appointed Prosecutor Provision came from. While the Nevada Constitution of 1864 served as a source for the proposed Constitution for the State of Deseret of 1872, and thus, in turn, as a source for many of the provisions of the Utah Constitution of 1896, see Cassell, supra, 1993 UTAH L. REV. at 802 , that does not appear to be the lineage for this provision. Neither the Nevada Constitution nor the draft constitution for the State of Deseret appear to contain language concerning the subject of victim-initiated prosecution (one way or the other). Indeed, so far as can be determined, the language was not imported from any other state constitution but rather is original to Utah and added during Utah's 1895 Constitutional Convention. ${ }^{7}$ Cf. SutTon, supra, at 177 (noting importance of state courts "marshaling the distinct state texts and histories and drawing their own conclusions from them").

${ }^{6}$ Justice Lee has recently examined some of the history around the time that Utah's Constitution was drafted, reporting that he could "find no instance of a private party [in Utah] indicting or trying a criminal suspect independent of state involvement." Gregory v. Shurtleff, 2013 UT 18, \7, 299 P.3d 1098, 1123 (Lee, J., concurring in part and dissenting in part). Nothing in this history is inconsistent with the view offered here. An appointment by a district judge of an "attorney pro tempore" (i.e., a temporary prosecutor) would not be an instance of a "private party" pursuing a criminal case "independent of state involvement," but rather the appointment of a prosecutor by the state judiciary at the request of the private party, who would then pursue a prosecution on behalf of the State to enforce the State's criminal laws. Indeed, perhaps envisioning the existence of prosecution by private actors, the Constitution as drafted in 1895 provided that "all prosecutions shall be conducted in the name and by the authority of the [State]." See Utah Const. of 1896, art. VIII, § 18.

7 Proposed Utah Constitutions were drafted in 1882 and 1887. See BICKMORE, CHARTER OF STATEHOOD, supra, at 35-39. Neither of those drafts contained language similar to 
What happened in Utah between 1872 and 1895, ultimately leading to the addition of the Court-Appointed Prosecutor Provision - not contained in any of the previously proposed Utah constitutions or any other of the 43 then-existing State constitutions? Here a "page of history is worth a volume of logic." Am. Fork City v. Crosgrove, 701 P.2d 1069, 1072 (Utah 1985) (quoting New York Trust Co. v. Eisner, 256 U.S. 345, 349 (1921) (Holmes, J.)). During this time, the residents of Utah territory witnessed firsthand the consequences of non-prosecution of various crimes. See generally Paul G. Cassell, Search and Seizure and the Utah Constitution: The Irrelevance of the Antipolygamy Raids, 1995 BYU L. Rev. 1, 10-13. Criminal prosecutions in the state at this time were directed by unelected federal outsiders, who myopically focused on politically-motivated antipolygamy prosecutions. See Gustive O. LARSOn, The “AmERicAnization” of UTAH FOR STATEHOOD 302 (1971) (describing "vindictive carpetbag methods" of law enforcement). Historians agree that the anti-polygamy prosecutions in Utah began most intensively following the passage of the Poland Act of 1874, which changed prosecuting practices in Utah by eliminating the offices of territorial marshal and attorney general and expanded the powers of the U.S. Marshal. See Tracy Panek, Search and Seizure in Utah: Recounting the Antipolygamy Raids, UTAH HIST. Q. 317 (1994).

This focus by federal law enforcement officials on polygamy prosecutions after 1874 meant under-enforcement of other criminal laws that directly affected day-to-day living conditions of Utah residents - particularly conditions for women. This sentiment

the Court-Appointed Prosecutor Provision, but these drafts were largely copycat drafts from the earlier 1872 proposal. Id. at 35,38 . 
is reflected, for instance, in a petition signed by 22,626 women of Utah and sent to Congress in 1876:

We ask to be relieved from the unjust and law-breaking officials forced upon us by the Government, and that we may have the jurisdiction of our own courts and the selection of our own officers, as we had in the past, when our cities were free from dram-shops, gambling-dens, and houses of infamy. As mothers and sisters, we earnestly appeal to you for help, that our sons may be saved from drunkenness and vice and our daughters from the power of the seducer....

H.R. Misc. Doc. No. $42,44^{\text {th }}$ Cong., $1^{\text {st }}$ Sess. $1-2$ (1876).

Given this unfortunate historical experience with lack of effective prosecution, it is hardly surprising that the drafters of the Utah Constitution would be concerned about preventing such under-prosecution in the future. Indeed, such concerns would have been shared not only by delegates to the Convention who were members of The Church of Jesus Christ of Latter-day Saints but also by those who were non-members (sometimes referred to as "Gentiles"). In construing Utah's Constitution, this Court should not overlook a period of religious reconciliation following the announcement of the Woodruff Manifesto in 1890 (effectively ending the practice of polygamy) and the consequent end of the anti-polygamy raids. See generally Jean B. White, Prelude to Statehood: Coming Together in the 1890s, 62 UTAH HIST. Q. 300 (1994). In drafting many provisions in Utah's Constitution - such as the search and seizure provision - the drafters simply came together to adopt existing law from other jurisdictions. See Cassell, 1995 BYU L. REV. at 3-10. But on other provisions, Utah's unique experience would have led to specialized provisions - such as the Court-Appointed Prosecutor Provision. 
Particularly at the time when the Utah Constitutional Convention was meeting, the general view in the country was that the "state posed no threat to American legal order. Rather, the threat came from defendants - the dangerous classes, which included rural criminals, urban criminals, rural paupers, urban paupers, and tramps. Accordingly, emphasis [in criminal justice] shifted ... to the ... theme of crime control." Lawrence Friedman, State Constitutions and Criminal Justice in the Late Nineteenth Century, 53 Albany L. ReV. 265, 271-72 (1989) (cleaned up). Consistent with this focus on crime control came a movement away from making private prosecution the primary mode of prosecution. As America became more populous and towns and cities began to grow in size, "[t]raditional notions of community responsibility for mutual welfare ... vanished in the impersonality of large urban concentrations." McDonald, supra, 13 AM. CRIM. L. REV. at 666. "In former times, law enforcement had relied greatly upon the ancient institution of the 'hue and cry' whereby victims called upon their fellow townsmen to assist in pursuing criminals. However, this practice became unworkable as the growth of urban centers inhabited by increasingly mobile populations developed in response to commercial needs." Id. at 653; see also Allen Steinberg, From Private Prosecution to Plea Bargaining: Criminal Prosecution, the District Attorney, and American Legal History, 30 CRIME \& DELINQ. 568 (1984); Robert M. Ireland, Privately Funded Prosecutors in the Nineteenth Century United States, 39 Am. J. Legal HIST. 43 (1995). Against this backdrop, an understanding emerges that the drafters of Utah's Constitution - both members of The Church of Jesus Christ of Latter-day Saints and 
Gentiles - sought to institute a system of public prosecution to most effectively control crime, while protecting victim-initiated prosecutions as an effective backstop for bringing criminals to justice when public prosecution failed. The text of the provision clearly indicates this intent, although the records of the Utah Constitutional Convention do not appear to contain any specific discussion of the Court-Appointed Prosecutor Provision. The Convention did, however, briefly discuss the role of public prosecutors and the financial support they would need to effectively prosecute criminals. ProcEEDINGS OF THE Constitutional Convention 1028 (1896). And at various points in the proceedings, there was allusion to far-flung counties in Utah, see id. at 1028-30, 1376-77, where more distant and less populated counties might lack the financial strength of more populous counties close to the State capitol.

The text of the Court-Appointed Prosecutor Provision thus reflects a need to ensure public-accountability and responsiveness to the needs of the local community and to crime victims. To control crime, a public prosecutor would be elected, as provided in art. VIII, $\S 10$ itself. The prosecutor would then have the first opportunity to prosecute a criminal. But following any failure or refusal to prosecute, a crime victim could approach an (elected) district court judge, art. VIII, § 5, who could then appoint a prosecutor pro tempore to ensure that criminal cases were effectively pursued and thus that society and crime victims would be fully protected. ${ }^{8}$

${ }^{8}$ It appears that Utah has exported this court-appointed prosecutor language to at least one other state. See Tenn. Const. art. VI, $\S 5$ ("In all cases where the Attorney for any district fails or refuses to attend and prosecute according to law, the Court shall have power to appoint an Attorney pro tempore."). The provision does not appear to have 


\section{From 1898 Through Much of the Twentieth Century, a Victim Had a Statutory Right to Seek to Initiate a Criminal Prosecution.}

In Utah, between the adoption of the Utah Constitution in 1895 and the early

1980s, victims do not appear to have often used the Court-Appointed Prosecutor

Provision (then contained in Utah Constitution, art. VIII, § 10). No mention of the

provision is found published Utah appellate decisions, at least so far as a Westlaw search

reveals. But a partial explanation for the dearth of constitutional invocations may be the fact that, from the earliest days of statehood, the Legislature specifically protected a right of victim-initiated prosecution by statute.

Some history: After Utah's admission as a state into the Union, it was necessary to generally revise Utah's laws. ${ }^{9}$ To that end, the Governor was authorized to appoint, and did appoint, a commission to revise the laws of our newly recognized state. The Code Commissioners undertook that revision, with the result that in January 1897, the Commissioners submitted to the Legislature a printed bill ready for enactment, that would take effect on January 1,1898 . The Legislature approved the bill substantially as prepared. The new Utah Code contained within it a Code of Criminal Procedure. See 1898 Revised Statutes of Utah, Title 76, $\S \S 4406-5173$.

Significantly, Utah's first Code of Criminal Procedure fully protected the right of a crime victim to seek directly judicial initiation of prosecution. Title $76, \S \S 4610-14$

generated much case law in that state. See generally Lewis L. LASKa, The TennesseE STATE CONSTITUTION 124 (2011).

${ }^{9}$ All of the facts described in this paragraph are taken from the "Preface" to the 1898 REVISED STATUTES OF UTAH (Lincoln, Neb., State Journal Co. 1897). 
contained provisions governing the filing criminal complaints. Section 4611 provided that "[e]very person who has reason to believe that a crime or public offense has been committed, must make complaint against such person before some magistrate having authority to make inquiry of the same." Id. at $\S 4611$ (emphasis added). Section 4612 provided that the magistrate would then examine "complainant" regarding "his knowledge of the commission of the offense charged" as well as other witnesses. Id. at $\S$ 4612. Thereafter, if based on the examination of witnesses the magistrate "was satisfied therefrom that the offense complained of has been committed[] and that there is reasonable ground to believe that the accused committed it," the magistrate judge "must . . . issue a warrant for arrest." Id. at $\S 4615$. Following issuance of a warrant, a private person was empowered to make an arrest if the offense was a felony, id. at $\S \S 4635$, 4638 , and peace officer was empowered to arrest for any offense, $i d$. at $\S 4637$.

Following any arrest, the magistrate with jurisdiction over the matter would conduct a preliminary examination. See $i d$. at $\S \S 4657-87$. This was very much a judicially-driven procedure, as the magistrate judge who was required to "first read to the defendant the complaint and the depositions of the witnesses examined on making the complaint." Id. at $\S 4665$. At the conclusion of the examination, the magistrate judge was required to hold the defendant to answer if sufficient evidence supported the charge: "If . . . it appear from the examination that a public offense has been committed, and that there is sufficient cause to believe the defendant guilty thereof, the magistrate must indorse on the complaint an order, signed by him," holding the defendant to answer. Id. 
at $\S 4675$ (emphasis added). To protect against a vindictive victim initiating an unfounded prosecution, the Code also provided that, if the defendant was not held to answer, and "if the magistrate finds that the prosecution was malicious or without probable cause, he shall enter such judgment on his docket and tax the costs against the complaining witness ...."Id. at $\S 4674$.

Because this whole process could be driven by a victim and a magistrate, the drafters of Utah's first criminal procedure code then had to consider what a prosecutor was obligated to do after a defendant was held to answer on victim-initiated or other complaints. The drafters decided that prosecutors would generally be duty-bound to file the charges, on penalty of contempt: "When a defendant has been examined and committed as provided in this code, it shall be the duty of the county attorney, within thirty days thereafter, to file in the district court of the county in which the offense is triable, an information charging the defendant with the offense for which he is held to answer, or any other offense disclosed by the testimony .... If the county attorney fails to file the information within the time specified, he shall be deemed guilty of contempt, and may be prosecuted for neglect of duty as in other cases." Id. at $\S 4692$. The drafters did allow a prosecutor the option of not filing an information, but only where a prosecutor wrote a detailed statement of reasons for not filing such charges. The judge would then review "such statement, together with the evidence filed in the case, and if upon such examination the court is not satisfied with such statement, the county attorney 
must be directed and required by the court to file the proper information and bring the case to trial." Id. at $\S 4693$.

In sum, consistent with the thrust of the Court-Appointed Prosecutor Provision, the first Utah Code of Criminal Procedure in 1898 contained detailed procedures to ensure that victim-initiated prosecution was possible and that prosecutor discretion not to pursue criminal charges was subject to close judicial review. It appears that these provisions remained in place for a significant part of the twentieth century. Although we have not done an exhaustive survey of the subject, through at least 1943, the Utah Code of Criminal Procedure maintained verbatim many of the provisions just discussed. See, e.g., Utah Code of 1943 at $§ 105-11-2$ (required "every person" with knowledge of crime to make complaint before a magistrate); $§ 105-17-1 \& 2$ (requiring prosecutor to file charges against preliminary examination and authorizing contempt action for failure to file charges).

\section{The 1984 Amendment to Article I, Section 16 Continued to Protect a Utah Constitutional Right for Victims to Seek a Court-Appointed Prosecutor.}

The victim's constitutional right to seek a court-appointed prosecutor was reaffirmed by the citizens of Utah in 1984, when the constitutional provision was reenacted as part of a broader constitutional reassessment. Perhaps a reason for retaining this constitutional provision was a change in the statutory provisions just described. By 1980, it appears that victims no longer had a clear statutory right to approach a judge to seek the filing of serious criminal charges. Instead, as of 1980, the Utah Code of 
Criminal Procedure provided that "Unless otherwise provided by law, no information may be filed charging the commission of any felony or class A misdemeanor unless authorized by a prosecuting attorney." Utah Code $§ 77-2-1$ (enacted in 1980).

Around the same time, however, the citizens of this state revisited the CourtAppointed Prosecutor Provision - and specifically retained and reaffirmed the right of victims to seek such appointments. This was done as part of a comprehensive review of the Utah Constitution's judicial article, article VIII. As one scholar explains, "By the early 1980s, it seemed that a thorough study of the [judicial] article was overdue, and the Constitutional Revision Commission took on the task. The result was a complete revision of the article, which was approved by the Legislature and by the voters in 1984 . This revision, which took effect in 1985 , resulted in the repeal of ten sections that were considered outdated or unnecessary .... The objective of the 1984 revision was to create a modern, unified court system and an independent judiciary." BICKMORE, THE UTAH StATE Constitution, supra, at 113.

With regard to the Court-Appointed Prosecutor Provision, it resided in a section in article VIII that also contained language regarding the structure of public prosecuting offices. During the redrafting of article VIII, considerable attention was paid to that language on prosecuting offices, as the consensus was that the language was "unduly restrictive and precluded the establishment of other prosecutorial structures such as district attorneys." State v. Robertson, 924 P.2d 889, 891 (Utah 1996) (citing OfFICE OF Legislative Research AND General COUNSEl, REPORT OF THE UtAH 
CONSTITUTIONAL REVISION COMMISSION 38 (Jan. 1984) (hereinafter “1984 CRC REPORT”).

The revisers of the Judiciary Article do not appear, however, to have had any doubt about retaining the Court-Appointed Prosecutor Provision. The only direct history we have been able to locate is from the Constitutional Revision Commission, which specifically recommended language for the section that would "retain[] the [judicial] authority to appoint prosecutors pro tempore, but clarif[y] that the supreme court is to be the appointing authority." 1984 CRC REPORT, supra, at 38. The result was that the citizens of this State approved the court-appointed prosecutor language that currently appears in Utah's Constitution, moved from article VIII, § 10 to article VIII, § 16:

Article VIII, Section 16. [Public prosecutors.] The Legislature shall provide for a system of public prosecutors who shall have primary responsibility for the prosecution of criminal actions brought in the name of the State of Utah and shall perform such other duties as may be provided by statute. Public prosecutors shall be elected in a manner provided by statute, and shall be admitted to practice law in Utah. If a public prosecutor fails or refuses to prosecute, the Supreme Court shall have power to appoint a prosecutor pro tempore.

Utah Const., art. VIII, $\S 16$ (emphases added) (approved by the voters in the 1984 general election).

Several things are noteworthy about this language. First, in 1984 the voters specifically decided that public prosecutors would have only the "primary" responsibility - not exclusive responsibility - for criminal prosecutions. This new language (not contained in Utah's constitution as originally drafted) validates the importance of court- 
appointed prosecutors as a backstop against failures by the "primary" mode of prosecution - i.e., public prosecutors.

Second, the new language broadened the grounds for appointing a prosecutor. While the original language authorized court appointment of a prosecutor when a public prosecutor "fail[ed] or refuse[d] to attend and prosecute according to law", Utah Const., art. VIII, $\S 10$ (1896) (emphasis added), the new amendment deleted that language of limitation - i.e., it was no longer a requirement that a prosecutor had failed or refused to prosecute "according to law," but only that the simple fact of a failure or refusal to prosecute existed.

Third, the new language clarified that the Judiciary (specifically this Court) had the power to appoint a "prosecutor pro tempore." Previously, the judiciary could appoint "an attorney pro tempore."

The Legislature designed these and other changes to enhance the prosecution of dangerous criminals. For example, Senator Haven J. Barlow, opining on the changes in the 1984 Amendment, stated that "[T]he judicial system in the state of Utah has been sensitive to what I think the people have tried to tell them and that is 'let's be a little bit tougher on the criminals.' And that has come through.” RECORDING OF SPEC. SESS.

Discussion of Substitute SJR 1, Held by the SENATE OfFICE OF THE UtAH

LegisLature (March 26, 1984). In addition, Senator Jack M. Bangerter argued that the changes were important to provide for swift punishment of criminals:

The reason that the criminals are making such a mockery out of the justice system is because we are continually changing the laws and destroying the 
precedents upon which justice is based .... I plead with you my colleagues

that we cooperate more with the judges and the judicial system and let the criminals among us know that we are going to stop this process and make it so the law is the same today as it was yesterday and will be the same tomorrow ... punishment would be swift and once again crime would not pay.

Id. Thus, one of the underlying goals of the 1984 amendment was to ensure swift and certain prosecution of criminals.

\section{This Court Should Use Its Power under the Court-Appointed Prosecutor Provision When a Public Prosecutor Fails or Refuses to Prosecute a Criminal Charge that is Clearly Supported by Probable Cause and Where Nothing Indicates that the Appointment Would Be Contrary to the Public Interest.}

While the Court-Appointed Prosecutor Provision clearly creates the ability for this Court to appoint a prosecutor, the issue remains as to what a victim needs to offer to this Court to justify the exercise of such authority. Read in context, the provision requires a crime victim (or other petitioner) seeking Supreme Court appointment of a prosecutor to prove three things - and only three things: (1) that the public prosecutor has failed or refused to prosecute criminal charges for a crime committed against her; (2) that the filing of criminal charges is supported by a clear showing of probable cause; and (3) that the appointment of a prosecutor is not contrary to the interests of justice. We explain each of these three requirements in the following sections.

\section{A. The Only Textual Requirement for Appointment of a Prosecutor Under Article VIII, Section 16 is a Showing that a Public Prosecutor Has Failed or Refused to Prosecute.}

Utah's Court-Appointed Prosecutor Provision is part of a three-sentence section of the judicial article of the Constitution (section 16), which is designed to establish a system for prosecuting crimes in which public prosecutors were the "primary" - but not 
the exclusive - means for doing so. Looking at the three sentences together, it becomes clear that the Court-Appointed Prosecutor Provision must be understood as the counterweight to the "primary" system of public prosecution. The way in which that counterweight springs into action is through Supreme Court appointment of a "prosecutor pro tempore" - i.e., a court-appointed prosecutor.

This understanding is supported by the provision's "history and purpose." American Bush, 2006 UT 40, $₫$ 24. The language allowing judicial appointment of a prosecutor was adopted as part of Utah's Constitution in 1895, following experience in the Utah territory with significant under-prosecution. See Part II.B, supra. It was adopted at a time when private prosecution was still widely available in America, if somewhat less often used. See Parts II.A \& II.B, supra. Utah's voters carried forward court-appointed prosecution in 1984, when they amended the State's judicial article - but specifically retained (and even modestly expanded) the Court-Appointed Prosecutor Provision. See Part II.D., supra.

This Court has previously interpreted article VIII, $§ 16$ consistently with this understanding. In State v. Robertson, 924 P.2d 889 (Utah 1996), this Court considered a challenge to the constitutionality of unelected city attorneys pursuing criminal charges. This Court began by noting that article VIII, $\S 16$ specifically refers to "public prosecutors" as elected officials, $i d$. at 890 , and city attorneys are not elected officials. This Court nonetheless refused to block prosecutions by city attorneys, explaining that “article VIII, section 16 confers only 'primary,' not 'exclusive,' responsibility on elected 
public prosecutors for the "prosecution of criminal actions." Id. at 891. The Court thus concluded that an "implicit residual or nonprimary responsibility" remained for prosecution outside of publicly elected prosecutors, which the city attorneys could exercise. $I d$. at 893 .

This Court also explained that "by specifically designating this Court as the entity empowered to appoint a prosecutor pro tem[pore] when a public prosecutor is delinquent in performing his or her obligation to file a criminal action, the text of article VIII, section 16 evinces more concern with a failure to exercise prosecutorial powers than with their abuse." Id. at 892 n.6 (emphasis added).

While this Court in Robertson clearly held that the public prosecutors are not the exclusive mode of criminal prosecution, it did not have occasion to explore the breadth of the last sentence in article VIII, section 16 - the Court-Appointed Prosecutor Provision. This Court has since made clear, however, that it is unnecessary for any particular public prosecutor to pursue a criminal prosecution. In Salt Lake City v. Peterson, 2010 UT 64, 245 P.3d 197, this Court explained that "it was not necessary for the Salt Lake City Prosecutor to take this case in order for any prosecution to occur," and noted (among various ways for the problem of non-prosecution to be addressed) that "article VIII, section 16 of the Utah Constitution states that '[i]f a public prosecutor fails or refuses to prosecute, the Supreme Court shall have the power to appoint a prosecutor pro tempore."” Id. at 911, n.4. 
The only textual prerequisite in the Court-Appointed Prosecutor Provision for appointment of such a prosecutor is a "fail[ure] or refus[al]" to prosecute. While this may seem like a straightforward requirement, it is worth considering what this phrase was intended to require. These two alternative grounds for court-appointed prosecution presume that a criminal case has been presented to the prosecutor for consideration, as only thereafter could some sort of "failure" or "refusal" to prosecute occur. But other than a showing of a failure or refusal to prosecute, the text of the Court-Appointed Prosecutor Provision contains no limitations on the judiciary's power to appoint a prosecutor. $^{10}$

A showing that a prosecutor has failed or refused to prosecute also obviates the need for a crime victim to resort to another vehicle might be able to use to secure a prosecution: the summoning of a grand jury. The essentially theoretical possibility of a grand jury indictment does not preclude a victim using the Court-Appointed Prosecutor Provision.

Utah Constitution, article I, $\S 13$, provides that the Legislature shall have power to prescribe " $[\mathrm{t}]$ he formation of the grand jury and the powers and duties thereof ...." This Court recently reviewed the origins of the grand jury provision. This Court explained that the provision was drafted against the backdrop of the nineteenth century view that grand jury investigations were "costly, slow, amateur, and prone to error ...." State v.

${ }^{10}$ Indeed, as mentioned earlier, in 1984, the voters specifically struck the earlier requirement that the appointment could only take place when a public prosecutor "fail[ed] or refuse[d] to attend and prosecute according to law." Utah Const. of 1896, art. VIII, § 10 (amended in 1984 and moved to art. VIII, § 16). 
Christiansen, 2015 UT 74, \ 17, 365 P.3d 1189. As a result, “our constitution’s framers .

. distrusted grand juries and allowed them to be appointed only in unusual circumstances.” Id. at $74, \uparrow 46$.

Given this historical distrust of grand juries, only judges could summon grand juries when Utah became a state. See 1898 Utah Code of Criminal Procedure $\S 4696$ (“A grand jury shall be drawn or summoned only when, in the opinion of the judge of the district court of the county, public interest demands it"). In fact, "[u]ntil 1990, no statute gave prosecutors the right even to request a grand jury ...."State v. Christiansen, 2015 UT 74, ๆ 36, 365 P.3d 1189, 1196.

Pursuant to its constitutional power in art. I, $\S 13$, today the Legislature has provided for summoning a grand jury in certain limited circumstances. See Utah Code $\S$ 77-10a-2. A victim of a crime could theoretically seek to use those procedures to seek the formation of a grand jury and, ultimately, a criminal prosecution of a crime. See Utah Code $\S 77-10 a-2(1)$ (a) (a panel of judges will "hear in secret all persons claim to have information that would justify the calling of a grand jury"). The focus of those procedures, however, appears to be securing an investigation of an alleged crime. See Utah Code $\S 77-10 a-3(2)$ (b) (panel of judges supervising grand jury may "refer a matter to the attorney general, county attorney, district attorney, or city attorney for investigation and prosecution" (emphasis added)); § 77-10a-10(1) \& (2) (noting grand jury’s “duty to inquire into offenses" and ability to obtain "documents or other evidence"). Indeed, under these procedures, a judges panel considering whether to summon a grand jury can, 
instead, refer a matter to a district attorney, presumably for investigation. Utah Code $\S$ 77-10a-3(1)(b). Thus, the existing grand jury procedures do not appear to be directed at circumstances such as this one, where a district attorney has previously investigated a crime through law enforcement agencies and declined to prosecute.

Even more problematic, the current grand jury procedures do not even require the summoning of a grand jury when good cause exists. See Christiansen, 2015 UT 74, ๆ 38 (panel of judges "hearing a private citizen's request may decline to summon a grand jury even if good cause exists" (citing Utah Code $\S 77-10 \mathrm{a}-2(2))$ ). In fact, it is hard to understand how a victim could trigger the summoning of a grand jury, as a prerequisite is a judicial finding that a grand jury is "necessary." Utah Code $\S 77-10 a-2(2)(a)$. Given the Court-Appointed Prosecutor Provision, it appears that it would not be "necessary" to summon a grand jury until after a victim had first sought court appointment of a prosecutor. $^{11}$

Also, from a policy perspective, using grand juries in sexual assault cases such as these could lead to further traumatization of the victims. Under the grand jury procedures, a person seeking the filing of charges "shall be placed under oath and examined by the judges conducting the hearings." Utah Code $\S 77-10 a-3(1)(c)$. It is

${ }^{11}$ Similarly inapposite to this case is a provision in the grand jury procedures authorizing appointment of a "special prosecutor" to conduct the grand jury proceedings. Utah Code $\S 77-10 \mathrm{a}-12(2)$. For reasons explained above, grand jury proceedings do not appear to be needed to investigate the Jane Does' cases. And, in any event, appointment of a special prosecutor is only permitted under this provision where the supervising judge makes a written finding that a conflict of interest exists for other prosecuting agencies, including the Utah Attorney General's Office. As we discuss in Part IX, infra, the Utah Attorney General's Office does not have a conflict of interest in handling these cases and, indeed, may be well situated to do so. 
unclear whether crime victims would be required to testify under oath to avail themselves of the grand jury provisions. ${ }^{12}$ But if victims were required to testify, this could lead to "secondary victimization" from an additional court appearance that should not be required to obtain the filing of charges. See Douglas E. Beloof, Paul G. Cassell, Margaret Garvin \& Steven J. Twist, Victims in Criminal Procedure 25 (4th ed. 2018) (discussing the fact that avoiding "secondary victimization" is a fundamental purpose of crime victims' rights enactments).

In any event, this Court should conclude that the existence of the statutory possibility for a crime victim to approach the grand jury does not preclude their protected constitutional right to pursue this petition. Given the historical distrust of and significant limitations placed on grand juries - not to mention the concomitant time, expense, and delay associated appointment of a grand jury of between nine to fifteen members to investigate and evaluate a case, see Utah Code $§ 77-10 a-4(1)$ - a victim's right to seek a prosecutor pro tempore should not be contingent on first seeking the summoning of a grand jury.

If, despite the foregoing arguments, the Court nonetheless concludes that a prerequisite to seeking relief under art. VIII, $\S 16$ is the need to first seek the summoning

${ }^{12}$ In the next sentence, the procedures indicate that "[h]earsay evidence may be presented at the hearings only under the same provisions and limitations that apply to preliminary hearings." Utah Code $§ 77-10 \mathrm{a}-3(1)(\mathrm{c})$. The issue of whether sexual assault victims have to testify at preliminary hearings has recently been the subject of (inconclusive) litigation before this Court. See State v. Hernandez, --P.3d---, $2018 \mathrm{WL}$ 3865317. The Jane Does in this petition adopt the position of Amici R.A., Utah Crime Victims Legal Clinic, and National Crime Victim Law Institute, who argued that victims need not testify at a preliminary hearing. But the issue has not been definitively resolved at this point. 
of a grand jury investigation, then the Jane Does would respectfully request an opportunity to do so.

\section{B. Article VIII, Section 16 Contains an Implicit Probable Cause Requirement for the Court to Appoint a Prosecutor.}

While failure or refusal to prosecute is the only textual requirement contained in the Court-Appointed Prosecutor Provision, one other requirement is implicit. It would make no sense for the judiciary to go to the trouble of authorizing a private prosecution in circumstances where the prosecution would be a nullity. From the earliest days of the Utah Constitution, for a prosecution to move forward in the criminal justice system, probable cause must exist that a crime was committed and that the defendant committed it. See, e.g., State v. Spencer, 15 Utah 149, 49 P. 302, 304 (Utah 1897) (noting the "probable cause" requirement for prosecution). In light of this fact, an implicit requirement of the Court-Appointed Prosecutor Provision is the existence of probable cause for a prosecution.

Traditionally, the probable cause requirement has been a prerequisite to private prosecution. Thus, shortly before the Utah Constitution was drafted, Supreme Court Justice Bradley explained that "every man in the community, if he has probable cause for prosecuting another, has a perfect right, by law, to institute such prosecution, subject only, in the case of private prosecutions, to the penalty of paying the costs if he fails in his suit.” Stewart v. Sonneborn, 98 U.S. 187, 198 (1879) (Bradley, J., dissenting).

A probable cause requirement is also consistent with the assumption that a courtappointed prosecutor would have to follow rules of legal ethics, which are applicable to 
prosecutors. The Utah Rules of Professional Conduct indicate that a prosecutor has a "special responsibility" to "[r]efrain from prosecuting a charge that the prosecutor knows is not supported by probable cause." Utah R. Prof. Conduct 3.8(a).

The Utah Constitution also assumes that such a "probable cause" determination lies within judicial competence. Article I, $\S 14$ of the Utah Constitution of 1896 provides that no warrants shall issue "but upon probable cause." This probable cause requirement calls on judges to assess the merits of collecting evidence in support of filing a criminal charge. Even more directly, article I, $\S 13$ of the Utah Constitution of 1896 allows criminal cases to move forward "by information after examination and commitment by a magistrate." The magistrate, of course, would be making a probable cause assessment about the underlying strength of the criminal case. The same determination accordingly lies within the competence of this Court, as acknowledged within the Constitution itself, when a victim presents a petition seeking a court-appointed prosecutor. Cf. Brant v. McSoley, 260 A.2d 443 (R.I. 1970) (sustaining a lower court's finding of lack of probable cause for a victim-initiated prosecution).

This probable cause requirement is one of many clear checks on any abuse of the Court-Appointed Prosecutor Provision. Of course, a probable cause determination automatically screens out any unfounded and merely mischievous complaints. See State v. Virgin, 2006 UT 29, ๆ 20, 137 P.3d 787, 792 (the "fundamental purpose" served by a probable cause determination "is the ferreting out of groundless and improvident prosecutions.”) Indeed, whenever this Court deploys article VIII, § 16, a defendant will 
be doubly protected against "groundless and improvident" prosecutions, since after the appointment of a prosecutor, a defendant would be constitutionally entitled to a preliminary examination to review the specific charges filed. See Utah Const., article I, § 13. As an additional safeguard, the defendant obviously must ultimately be proven guilty beyond a reasonable doubt at trial before suffering any punishment. And if at any point in the process the victim makes a false statement about the crime, the victim herself can be prosecuted criminally for such an offense. See Utah Code $\S \S 76-8-501$ to 503 (making a false statement during trial a second-degree felony and a false statement to mislead a public official a misdemeanor). The victim is also subject to a civil action for malicious prosecution. See, e.g., Hodges v. Gibson Products Co., 811 P.2d 151 (Utah 1991) (approving malicious prosecution action against alleged victim of crime who falsely instituted criminal prosecution). As a result, "while there is the possibility of frivolous suits and vindictive behavior by some complainants [who initiate a prosecution], abuses are checked and deterred by the court's discretion and by the various other remedies available for malicious prosecution." State of New Jersey v. Kinder, 701 F. Supp. 486, 492 (D.N.J. 1988).

On top of all these safeguards, this Court recognized another protection against abusive prosecutions in Robertson. In that case, a defendant had raised "the specter of 'unaccountable' city attorneys harassing the citizenry and abusing their discretion by filing unfounded or poorly considered charges." 924 P.2d at 892 n.6. The Court of Appeals had addressed such concerns by, among other things, noting "that the attorney 
general retains common law authority to intervene in any case involving the prosecution of a state criminal statute." Id. (citing State v. Robertson, 886 P.2d 85, 90-91 (Utah App. 1994)). This Court stated that "[a]lthough we do not address that portion of the Court of Appeals' opinion, we do note that as a general matter we have previously held that the attorney general retains common law powers of the type described by the Court of Appeals. 924 P.2d at 892 n.6 (citing Hansen v. Utah State Retirement Bd., 652 P.2d 1332, 1337 (Utah 1982); State v. Jiminez, 588 P.2d 707, 708-09 (Utah 1978); Hansen v. Barlow, 456 P.2d 177, 178-80 (Utah 1969)). The ability of the Attorney General to intervene provides yet another safeguard against the speculative possibility of an abusive court-appointed prosecutor.

Finally, in this petition, the Jane Does present not marginal cases of probable cause, but rather very clear cases of probable cause. Presumably this will be the situation with other victims who go to the time and trouble of petitioning this Court seeking appointment of a prosecutor - and the expenditure of judicial time and energy evaluating such petitions can be mostly easily justified in such circumstances. Accordingly, the Court may wish to interpret the probable cause requirement for seeking appointment of a prosecutor to be not simply the bare-bones minimum showing of probable cause, but rather a clear showing of probable cause.

\section{The Court Can Consider Interests of Justice Under Article VIII, Section 16 in Appointing a Prosecutor.}

Finally, it is noteworthy that the Court-Appointed Prosecutor Provision does not require this Court to appoint a prosecutor in every single case in which prosecution has 
been refused and clear probable cause exists. The ultimate safeguard against abusive prosecution is this Court. The Provision is written so that this Court has "the power" to appoint a private prosecutor. But the question naturally arises of when, following a properly presented petition, the Court should exercise its power to appoint a prosecutor.

A partial answer to this question can be immediately derived from the text of article VIII, § 16 itself. As currently drafted, the provision indicates that the Legislature "shall provide for a system of public prosecutors who shall have primary responsibility for the prosecution of criminal actions brought in the name of the State of Utah ...." Utah Const., art. I, § 16 (italicized language added via 1984 amendment). Thus, the standards that the Court employs for evaluating (for example) victim-initiated petitions for prosecution should not be so demanding as to turn public prosecutors from the constitutionally-envisioned "primary" mode of proceeding in criminal cases to the exclusive mode. As this Court has explained, rejecting a challenge to unelected city prosecutors bringing criminal charges, 'article VIII, section 16 confers only 'primary,' not 'exclusive,' responsibility on elected public prosecutors for the 'prosecution of criminal actions.' It follows that a residuum of prosecutorial power exists ...” outside the realm of public prosecutors. State v. Robertson, 924 P.2d 889, 891 (Utah 1996).

The obvious - although somewhat open-ended - answer to the question of when this Court should appoint a prosecutor is that the Court should do so when it is in the interests of justice. The appellate courts of this state have applied an interest of justice standard hundreds of times. See, e.g., Westlaw search ("interest +2 justice" in Utah state 
database producing hundreds of results). For example, this Court has familiarity in applying an interest of justice standard in the context of Rule 65B petitions. See, e.g., Adams v. State, 2005 UT 62, \ 14, 123 P.3d 400. And the Court's own Rule 24(a) authorizes trial courts to grant a new trial "in the interest of justice if there is any error or impropriety which had a substantial adverse effect upon the rights of a party." Utah R. Crim. P. 24(a). Similar standards exist in civil cases. See, e.g., Watson v. Watson, 561 P.2d 1072, 1074 (Utah 1977) (noting trial court power to reopen divorce proceedings to the extent it is "necessary and desirable in the interests of justice").

The judiciary is also familiar with applying an interests of justice standard in circumstances analogous to those presented here. As one specific example, the flipside of the power to initiate a criminal prosecution is the power to terminate a criminal prosecution. This Court has promulgated its own rule of criminal procedure - Rule $25-$ allowing district courts, on their own initiative, to dismiss criminal charges upon a showing of "substantial cause and in the furtherance of justice." Utah R. Crim. P. 25(a) (emphasis added). Just as courts in this State can reject charges when doing so promotes justice, upon the filing of a proper petition and a showing of clear probable cause, the judiciary should authorize the filing of criminal charges when doing so is in furtherance of justice. Cf. People v. Clancey, 299 P.3d 131, 142 (Cal. 2013) (reading judicial power to dismiss in "furtherance of justice" broadly).

The interests of justice are served whenever a prosecution is "fair and right." BLACK's LAW DictionARY 96 (10 ${ }^{\text {th }}$ ed. 2014) (defining “interests of justice”). This 
broad and flexible standard gives the Court this ability to assess the broad array of issues that will arise when petitions are filed seeking appointment of a prosecutor. For example, relevant and important issues of under-prosecution of rapes committed against women (discussed in Part VII.C, infra), possible conflicts of interest when prosecutions of government officials are considered (discussed in Part VI.C, infra), and discriminatory treatment of rape victims who are examined by one particular nursing agency (discussed in Part VII.J, infra) all fit comfortably within an interests-of-justice determination.

Overarching any individualized consideration, this Court should weigh in the balance the fact that "the enforcement of a state's criminal code constitutes a clear and substantial public policy.” Fox v. MCI Commc'ns Corp., 931 P.2d 857, 860 (Utah 1997) (citing Hodges v. Gibson Products Co., 811 P.2d 151, 166 (Utah 1991)). In this case, for example, prosecution of sexual violence serves to provide redress to women and other groups who are disproportionately harmed by such violence. Appointment by the court of a prosecutor to pursue well-founded criminal charges will, in the absence of any contrary evidence, be itself in the interests of justice.

\section{The Victims' Rights Amendment, Utah Const., art. I, § 28, Supports Interpreting the Court-Appointed Prosecutor Provision to Allow Prosecutions that Promote Fairness to the Victim.}

The interpretation of the Court-Appointed Prosecutor Provision just offered is fully supported by another important - and more-recently adopted - section in the Utah Constitution: The Utah Victims' Rights Amendment. In 1994, the Legislature proposed and Utah's citizens approved an amendment extending state constitutional protections to 
crime victims throughout the criminal justice process. See generally Paul G. Cassell, Balancing the Scales of Justice: The Case for and Effects of Utah's Victims' Rights Amendment, 1994 Utah L. Rev. 1373. ${ }^{13}$ Among the rights extended to crime victims by the amendment was the right " $[\mathrm{t}] \mathrm{o}$ be treated with fairness, respect, and dignity ... throughout the criminal justice process." Utah Const., art. I, § 28(1)(a). This provision "effects a fundamental change in the criminal justice system. Instead of adopting a twoparty, State v. Defendant, paradigm, this provision requires that the system consider interests of third parties, specifically crime victims. Unfair practices that deny crime victims respect or dignity are unconstitutional under the Amendment." Cassell, supra, 1994 UTAH L. REV. at 1387.

While the Victims' Rights Amendment does not specifically discuss courtappointed prosecutors, the Amendment extends victims' rights "throughout the criminal justice process." Utah Const., art. I, $\S 28(a)(1)$. And the opening words of the Amendment extend rights to victims in order to "preserve and protect victims' rights to justice and due process ...." Utah Const., art. I, § 28(1). Moreover, the Legislature, as part of its constitutional right to enforce and implement the Amendment, see Utah Const., art. I, § 28(4), directed that the provisions should be construed "to assist the victims of crime.” Utah Code § 77-38-12(1); see also Cassell, supra, 1994 UTAH L. REV. at 1422 n.252 (discussing this provision).

13 This law review article was reviewed by Senate sponsor Craig A. Peterson and House sponsor R. Lee Ellertson and endorsed as a statement of the drafters' intentions. 1994 UTAH L. REV. at 1393 n.*. 
Evaluating the Victims' Rights Amendment and supporting legislation, this Court has held that "Utah law now recognizes that victims have fared poorly in the criminal justice system and that they are to be more involved in the process of punishing the acts of which they became unwilling participants.” State v. Blake, 2002 UT 113, ๆ 16, 63 P.3d 56, 60. In light of these constitutional and statutory provisions, it would be inappropriate - indeed, unconstitutional - for the Court not to appoint a prosecutor when a crime victim makes the appropriate showings, including a showing that appointment is in the interests of justice. Nothing could be further from treating a crime victim with "fairness" and "justice and due process" than to deny appointment of prosecutor when the interests of justice demand doing so. Accordingly, Utah's Victims' Rights Amendment fully supports the interpretation of the Court-Appointed Prosecutor Provision offered here.

$$
* * *
$$

To briefly recapitulate, for all the reasons just explained, a crime victim seeking appointment of a prosecutor under article VIII, $\S 16$, should be required to demonstrate three - and only - three things:

(1) The appropriate public prosecutor has failed or refused to pursue criminal charges that have been presented to the prosecutor;

(2) The criminal charges are supported by clear probable cause; and

(3) The filing of the criminal charges is in the interests of justice. 


\section{Under Article VIII, Section 16, This Court Should Evaluate Whether to Appoint a Prosecutor Based on Merits of the Proposed Prosecution Rather than Evaluating the Previous Declination of the Public Prosecutor.}

The interpretation of article VIII, section 16 just offered is based on a detailed review of the text of the provision, as well as the historical evidence of the framers' intent and related context. See American Bush, 2006 UT 40, \ 10, 140 P.3d 1235 (highlighting all these factors as important considerations in interpreting state constitutional provisions). But the Jane Does acknowledge that their interpretation might be regarded as somewhat different than that provided in this Court's brief memorandum order in In re Request for Appointment of Special Prosecutor by Eric Hunting, No. 960558, 939 P.2d 177 (Mem.) (1997) (hereinafter “In re Hunting”). The memorandum order in In re Hunting seems to have read the required showing for court appointment of a prosecutor as some sort of proof of an abuse of discretion by the public prosecutor. This Part demonstrates that the memorandum order is not binding in this case - or, if binding, should be reconsidered based on full briefing and argument. This Section then explains why article VIII, section 16 does not employ an abuse of discretion standard, which would require this Court to intrusively focus on why the public prosecutor made the decision not to prosecute. Instead, the focus should be on the underlying merits of the petition presented to this Court. 


\section{A. This Court's Memorandum Order in In re Hunting Mentioning an Abuse of Discretion Standard is Not Controlling Precedent on this Issue.}

Perhaps the only decision by this Court to involve a petition for appointment of a prosecutor under Utah Const., art. VIII, § 16, is its memorandum order In re Hunting, No. 960558, 939 P.2d 177 (Mem.) (1997). ${ }^{14}$ The terse memorandum order, only two paragraphs long, simply concluded that petitioner Eric Hunting had "not met his burden of demonstrating that the Vernal City prosecutor has acted outside the legitimate scope of the discretion conferred upon a prosecutor." Id. (citing State v. Mohi, 901 P.2d 991 and finding no abuse of discretion).

The In re Hunting memorandum order and its reference to an abuse of discretion standard should not be regarded as precedential. The issue of whether an abuse of discretion standard applies to the Court-Appointed Prosecutor Provision was never briefed and argued to this Court, but rather was simply assumed. As described in the terse published reports from this Court on the case, Mr. Hunting filed a "request" with the Court for appointment of a prosecutor to pursue alleged failures of the Vernal City prosecutor to pursue criminal violations by the Vernal City Chief of Police. In re Request for Appointment of Special Prosecutor by Eric Hunting, No. 960558, 930 P.2d 904 (Mem.) (1997). Records in the State archives reveal that the request was a very brief letter, written by a non-attorney, Eric Hunting. [App. at 213.] Without citing any legal authority other than article VIII, section 16 of the Utah Constitution, Mr. Hunting

${ }^{14}$ The designation of the opinion as "Mem" - i.e., "memorandum" - appears in the Westlaw version of the case. In 1997, it appears that the official reports of Utah Supreme Court decisions were via Westlaw's Pacific Reporter system. 
summarily requested appointment of a prosecutor to prosecute a Vernal City police officer for the purported crime of not having on file the required oath of office. [App. at 213.] Curiously, attached to his letter was correspondence from the Vernal County Attorney stating that the Chief of Police did, indeed, have the required oath of office on file. [App. at 214-15.]

In response to that fleeting request, this Court ultimately entered a one-paragraph order stating that "[a]s one requesting the appointment, Mr. Hunting has the burden of demonstrating that the failure or refusal of the Vernal City prosecutor to prosecute constitutes an action outside the legitimate scope of the prosecutor's discretion." 930 P.2d 904 (Mem.) (1997) (citing Mohi). The Court then gave Hunting an opportunity to "file any additional materials he thinks necessary to persuade the court that he has met this burden." Id. The Court's brief order concluded by stating: "The court will take the matter under consideration, presumptively without oral argument." Id.

As is readily apparent, in entering that order, the Court essentially assumed that an abuse of discretion standard was applicable to petitions under art. VIII, § 16. It does not appear to have received any briefing on the issue - simply a short letter from a pro se litigant. Nor did the Court give interested parties (such as the Utah Council on Victims of Crime) any opportunity to seek to participate in the case, via amicus briefing or otherwise, on what was an important state constitutional issue of first impression. Indeed, the Court never received any briefing on the state constitutional law issues. Cf. State v. Houston, 2015 UT 40, \ 65, 353 P.3d 55 (“As a general rule, we 
decline to rule or opine on [state constitutional law] issues that are not briefed by the parties.”); State v. Worwood, 2007 UT 47, ๆ 18, 164 P.3d 397, 405 (“Inadequate briefing denies our fledgling state constitutional analysis the full benefit of the interested parties' thoughts on these important issues."). Vernal City filed a response to Hunting's request, but it did not discuss the meaning of article VIII, § 16. [App. at 220-27.] Instead, Vernal City argued that it had made a decision within its discretion (as this Court's earlier order suggested) - specifically a non-prosecution decision that was obviously correct because the officer in question had, indeed, taken his oath of office.

Shortly thereafter, the Court entered its memorandum order, denying the petition. Perhaps the reason for disposing of the petition so rapidly was that this Court perceived a lack of merit - indeed, frivolity - in the claims being raised. But in any event, given the way the case unfolded, all that it produced was the short memorandum order concluding Mr. Hunting had not carried his burden of persuasion.

This Court has previously explained that " $[\mathrm{m}]$ emorandum decisions are intended to address cases which do not present novel issues of law on appeal, with reference to well-established precedent arising either from case law or from unambiguous statutory language." State v. Robison, 2006 UT 65, 1 27, 147 P.3d 448 (noting that because such decisions "apply the law but do not develop it and therefore are of interest only to those with a stake in the outcome"); accord Grand County v. Rogers, 2002 UT 25, ๆ 7, 44 P.3d 734 ("Memorandum decisions are . . intended to be of use only to the lower tribunal whose work is the subject of the appeal, and to the litigants and parties in the case."). 
As perhaps the first decision to interpret this important constitutional provision, this Court does not appear to have intended for its two-paragraph order in Hunting to settle important constitutional questions of crime victims' rights. Accordingly, Hunting should not be regarded as controlling here.

\section{B. If In re Hunting is Precedential, It Should Now be Reconsidered Based on Full Briefing and Argument.}

If the Court believes that the brief memorandum order in Hunting has precedential force, then at a minimum, the Court should reconsider the issue of how to interpret article VIII, $\S 16$ and whether it incorporates an abuse of discretion standard. This Court has made clear that "[stare decisis] is neither mechanical nor rigid as it relates to courts of last resort." Eldridge v. Johndrow, 2015 UT 21, 『 22, 345 P.3d 553, 557. This Court has "identified two broad factors that distinguish between weighty precedents and less weighty ones: (1) the persuasiveness of the authority and reasoning on which the precedent was originally based, and (2) how firmly the precedent has become established in the law since it was handed down." Id. Analyzing these two factors makes clear that Hunting is, to put it mildly, not a "weighty" decision.

Turning to the persuasiveness of In re Hunting's reasoning, the only reason that the memorandum decision offered for reading an abuse of discretion standard into the Court-Appointed Prosecutor Provision was a citation to State v. Mohi, 901 P.2d 991 (Utah 1995). Hunting failed to include a pin-point, page reference for its citation to Mohi. Notably, in Mohi, the Court did not even cite article VIII, $\S 16$, much less discuss how the provision should be interpreted. To be sure, while analyzing the issues at play in 
that case (the constitutionality of a "direct-file" statute authorizing prosecutors to directly file certain serious adult criminal charges against juveniles), Mohi did briefly discuss "traditional prosecutor discretion." Id. at 1002-03. But that terse analysis hardly sheds light on how a state constitutional provision obviously designed to address prosecutorial failures or refusals to file charges should be interpreted.

The second factor - how firmly rooted a decision has become - also counsels against giving In re Hunting any weight. So far as we can tell, the Hunting order has never been cited in another court opinion. As explained above, Hunting is inconsistent with a proper understanding of the original meaning of article VIII, $\S 16$ (and its predecessor article VIII, § 10). Reconsidering Hunting's abuse-of-discretion language, after full briefing and argument, will not create any "injustice or hardship." Eldridge v. Johndrow, 2015 UT 21, $\uparrow$ 22, 345 P.3d 553, 557. Here, the Court's reconsideration would place the Court-Appointed Prosecutor Provision within the strong tradition of victim-initiated prosecution and thus establish that In re Hunting is not only "erroneous" but also that "more good than harm will come by departing from [the] precedent." State v. Mauchley, 2003 UT 10, ๆ 11, 67 P.3d 477, 481 (Utah 2003).

\section{Article VIII, Section 16 Does Not Require Judicial Evaluation of the Merits of Adequacy of a Prosecutor's Declination Decision.}

On the merits of the issue, in suggesting that Utah's Court-Appointed Prosecutor Provision creates an abuse-of-discretion standard, the In re Hunting order was simply wrong. Under the Provision, the Court's decision whether to appoint a prosecution rest 
on the merits of that petition - not evaluation of the reasons for a prosecutor's inaction. This conclusion follows naturally from the text of the provision, its underlying history, and the unworkability of an abuse-of-discretion standard.

For starters, the text of the Court-Appointed Prosecutor Provision does not even hint at an abuse of discretion standard. As initially adopted in 1896, the provision gave district courts the "power to appoint an attorney pro tempore" in "all cases where the attorney for any county ... fails or refuses to attend and prosecute according to law." Utah Constitution of 1896, art. VIII, $\S 10$ (emphasis added). An abuse of discretion standard makes no sense in interpreting this language. For example, it is obvious that a county prosecutor could "fail to attend and prosecute" a court hearing for any number of reasons - including death, illness, inability to travel to the court, scheduling difficulties, etc. Indeed, in 1896, lacking modern communication devices and expansive road networks, situations where a prosecutor might have been unavailable for perfectly legitimate reasons are easy to imagine. In such cases where a prosecutor was absent, it could hardly be said that the prosecutor abused his discretion by failing to attend and prosecute - but Utah's constitutional drafters wanted to ensure that the prosecution would not be blocked by the prosecutor's absence. Accordingly, the drafters specifically authorized court appointment of a "prosecutor pro tempore" - i.e., a temporary prosecutor who could insure the case would move forward even where prosecutors had acted reasonably. 
Interestedly, the fact that a prosecutor might be unavailable is not simply an historical artifact from the nineteenth century. Indeed, during the debates regarding the 1984 Amendment to the Court-Appointed Prosecutor Provision, Senator Karl N. Snow discussed other provisions in Utah Const., art. I, $\S 16$, explaining that " $[t]$ he constitution requires that every county have its own prosecutor in the person of the county attorney. Now, in some of our rural counties, this is not feasible." RECORDING OF SPEC. SESS. Discussion of Substitute S.J.R. 1, Held by the Senate OfFICE OF THE UtAH LEGiSLATURE (March 26, 1984). This discussion confirms that one concern being addressed by the Court-Appointed Prosecutor Provision was, at its text indicates, a simple "failure" to prosecute rather than the underlying reasons a prosecution was not moving forward. An abuse of discretion standard is simply inconsistent with that part of the Court-Appointed Prosecutor Provision.

Given that an abuse of discretion standard does not apply to the "failure" to prosecute, it would make little sense to read it into the adjoining word "refusal" in article VIII, section 16. Neither word is modified by an adjective that provides a textual basis for such a construction - e.g., the drafters (both in 1895 and 1984) did not condition appointment of a prosecutor on some sort of "unreasonable" refusal to prosecute. Instead, a victim was given the ability to seek appointment of a prosecutor whenever a prosecutor "fails or refuses" to prosecute - nothing more and nothing less.

Moreover, read in context with other provisions of the 1896 Constitution, article VIII, $§ 16$ was not designed to address situations of prosecutorial abuse of discretion. As 
originally drafted, Utah's Constitution addressed that subject in Article VIII in a provision contained several sections earlier. Article VIII, § 4. That section gave the Utah Supreme Court "original jurisdiction to issue writs" against government officials specifically authorizing "writs of mandamus, certiorari, prohibition, quo warranto and habeas corpus" (emphasis added). As originally understood, a mandamus petition could be pursued where someone could show a "peculiar interest separate and distinct from that of the community in general.” Gregory v. Shurtleff, 2013 UT 18, ๆ 83, 299 P.3d 1098 (Lee, J., concurring in part and dissenting in part). A prosecutor who failed to prosecute a victim's attacker for no good reason or grossly abused his discretion could likely be subject to a writ of mandamus under $\S 4$. See, e.g., State ex rel. Master v. Cleveland, 661 N.E.2d 180 (Ohio 1996) (reviewing petition for writ of mandamus and noting that "[a] prosecuting attorney will not be compelled to prosecute a complaint except when the failure to prosecute constitutes an abuse of discretion"); Brack v. Wells, 40 A.2d 319, 321 (Md. Ct. Apps. 1944) (noting mandamus against a prosecutor for failing to file discretionary charges will not lie "[u]nless that discretion is grossly abused") (citing 38 Corpus Juris 623). See generally Note, The Use of Mandamus to Control Prosecutorial Discretion, 13 AM. CRIM. L. REV. 563 (1976). Thus, it appears that the Constitution's drafters were addressing something other than the prosecutor's discretion when they added to article VIII not only the writs provision but also a separate Court-Appointed Prosecutor Provision. 
In addition, interpreting article VIII, $\S 16$ to provide for judicial review of the underlying merits of a prosecutor's decision not to prosecute would be in tension with the structure of the Constitution as adopted in 1896, which generally provided by separation of powers. See Utah Const. art. V, $\S 1$. Against this backdrop of separated powers, the role of the Court-Appointed Prosecutor Provision comes clearly into focus. It was designed not to provide for judicial review of the substantive merits of prosecutorial decisions - something not normally done by the judiciary - but rather simply to provide a means for an independent assessment of whether a prosecutor for a particular case would be useful where a public prosecutor had failed or refused to move forward. This inquiry does not involve judicial actors second-guessing a previous prosecutorial decision, but rather making a separate decision about the merits of a criminal case - and, if appropriate, appointing a prosecutor to proceed with that case. Indeed, as this Court has specifically explained, the Court-Appointed Prosecutor Provision "evinces more concern with a failure to exercise prosecutorial powers than with their abuse." See Robertson, 924 P.2d at 892. After appointment of a "prosecutor pro tempore," the judiciary would not be involved in the prosecution, which would be handled by the court-appointed prosecutor in an appropriate way.

Finally, the idea that the Court-Appointed Prosecutor Provision somehow contains an abuse of discretion standard founders for other reasons as well. While In re Hunting briefly asserted that it was up to the petitioner to demonstrate an abuse of discretion by the prosecutor, the decision offered no guidance as to how this showing might be made. 
Presumably this is because prosecutors almost invariably decide not to prosecute cases based on "non-apparent, unarticulated, difficult-to-weigh factors." Norman Abrams, Internal Policy: Guiding the Exercise of Prosecutorial Discretion, 19 UCLA L. REV. 1, 4 (1971). Judicial review of the wisdoms of such decisions is essentially impossible, particularly if the judiciary does not compel prosecutors to develop guidelines for charging decisions. See James Vorenberg, Decent Restraint of Prosecutorial Power, 94 HARV. L. REV. 1521, 1571 (1981) ("Without guidelines, courts have little or no basis on which to evaluate prosecutorial actions, and the limitations [against abuse of discretion] therefore become meaningless"); Peter L. Davis, The Crime Victim's "Right" to a Criminal Prosecution: A Proposed Model Statute for the Governance of Private Prosecutions, 38 DePaUl L. REV. 329, 375 (1989) ("regardless of the steps taken to make the exercise of discretion within prosecutors' officers more visible, that exercise will always be essentially unchallengeable without a full airing of the case in a completely open forum"). This Court should not interpret the Court-Appointed Prosecutor Provision to require crime victims to demonstrate that decisions based on such hidden and obscure factors were an abuse of discretion, because doing so would often be sending them on a fool's errand.

In addition, showing an abuse of discretion by the prosecutor will inevitably involve complicated questions as to whose discretion is under evaluation. The Salt Lake District Attorney's Office, for example, contains dozens of different prosecutors spread through different sections. See Abrams, supra, 19 UCLA L. REV. at 6 ("prosecution 
offices are particularly notorious for their high rate of turnover" and thus "the problems of trying to maintain consistency among many different decisions makers must be reckoned with"). An abuse of discretion standard would be complicated to administer, as it would presumably necessitate comparing actions of multiple persons taken at multiple times.

Finally, prosecutors themselves may not want this Court to adopt an abuse of discretion standard. Traditionally, such standards involve judicial review of an articulated reason for a decision by an executive branch agency, followed by consideration of the adequacy of those reasons. See, e.g., Drake v Industrial Comm'n of Utah, 939 P.2d 177, 181-82 (Utah 1997). Such an inquiry may involve whether the findings of the executive branch agency are supported by "substantial evidence," among other things. $I d$. at 181 . Judiciary inquiry into an internal prosecutorial decisionmaking process will necessarily be more intrusive than a separate inquiry into the historical facts regarding a potential criminal case - facts often readily-available (as in this case) in police reports.

At a minimum, if this Court applies an abuse of discretion standard, a crime victim seeking appointment of a private prosecutor would not have to take a prosecutor's representations at face value. Instead, as with other litigation involving constitutional rights, the victim would be entitled to reasonable discovery on the issues. As an illustration of this point, the Jane Does in this case (as a fallback, protective matter) seek such discovery into the prosecuting practices of the Salt Lake District Attorney's Office 
in the immediately following section of this brief. But the simplest way for the Court to avoid entering the abuse-of-discretion quagmire is simply to set up a different inquiry all together - which is what the Jane Does propose.

For all these reasons, Utah's Court-Appointed Prosecutor Provision should not be interpreted as containing an abuse of discretion standard.

\section{If Article VIII, Section 16 Requires Evaluation of the Adequacy of a Prosecutor's Decision, the Jane Does Are Entitled to Discovery Regarding the Basis of the Prosecutor's Decision.}

If the Court nonetheless concludes that an abuse of discretion standard applies to petitions brought under the Court-Appointed Prosecutor Provision, the Jane Does would request an opportunity to demonstrate that an abuse of discretion has occurred in their cases - after they have received appropriate discovery.

If this Court is going to resolve their petition on an abuse of discretion standard, the Jane Does would be entitled to discovery concerning the specific reasons why the prosecutors refused to prosecute their cases and whether these reasons are pretexts, rest on unconstitutional (state or federal) grounds, or otherwise rest on "rape myths" (as discussed in Part VII.E, infra). In particular, the Jane Does would request an opportunity to depose the prosecutors who made the decision not to file charges in their cases. The Jane Does would also request that the Court direct the Salt Lake District Attorney's Office to provide all information relevant to the decision not to prosecute, including any communications within the Office regarding the particular decisions in their cases and prosecutorial guidelines regarding sexual assault cases in general. The Jane Does 
respectfully submit that, with appropriate discovery, they could demonstrate that the decisions not to prosecute their cases constituted clear abuses of discretion. They respectfully request guidance from this Court as to what steps they can take in support of showing an abuse of discretion. Of course, because this Court has original jurisdiction over this petition, is not limited to "conduct[ing] a review in [its] appellate capacity, but rather serve[s] as the forum in which claims are initially heard." Mouty v. The Sandy City Recorder, 2005 UT 41, \ 10, 122 P.3d 521, 525 (internal citation omitted). Because the claims are being "initially heard" before this Court, if this Court applies an abuse of discretion standard, it should also ensure that the victims have all information relevant to litigating under that standard.

\section{The Court-Appointed Prosecution Provision Represents Utah's Unique Solution to the Well-Recognized Problem of Under- Prosecution.}

The problem of how victims can obtain review of inappropriate decisions by prosecutors failing to pursue well-founded criminal charges is not unique to Utah. This Part explains why this is a recurring problem, to which Utah's Court-Appointed Prosecutor Provision is addressed. This Part first discusses why crime victims need to be able to have an opportunity to obtain the filing of criminal charges when a public prosecutor has decided not to file any. This Part then situates Utah's Court-Appointed Prosecution Provision within a larger body of law for other states designed to ensure that prosecutors do not have unreviewable discretion to refuse to file criminal charges. 


\section{A. Victim-Initiated Prosecution Continues to Serve Valuable Social Purposes for Crime Victims and the Public at Large Today.}

Utah's Court-Appointed Prosecutor Provision represents a far-sighted anticipation

of the need for crime victims to be able to independently pursue the filing of criminal charges when public prosecutors have declined to act. This Provision must be assessed against the broader crime victims' rights movement, which reflects a consensus in Utah and elsewhere around the country that victims deserve to actively participate in the criminal justice process. See Payne v. Tennessee, 501 U.S. 808, 834 (1991) (Scalia, J., concurring) (noting "nationwide 'victims' rights' movement"). Victim involvement in criminal prosecutions is not a matter of vengeance, but rather a recognition that victims have suffered terrible wrongs at the hands of criminals. For example, the U.S. Supreme Court has directly held that "in the administration of criminal justice, courts may not ignore the concerns of victims." Morris v. Slappy, 461 U.S. 1, 14, (1983). And this Court, too, has recognized that in some circumstances a crime victim can proceed in the criminal justice process "not through the intermediary of the prosecution" but rather by “a direct filing by the victim." State v. Brown, 2014 UT 48, ๆ 18, 342 P.3d 239, 242 (discussion restitution). See generally Beloof, CASSEll, GARVIN \& TwIST ET AL., supra, at 30-36 (discussing the crime victims' movement); Shirley S. Abrahamson, Redefining Roles: The Victims'Rights Movement, 1985 UtAH L. REV. 517. For example, in 1982, a Presidential Commission called for numerous changes in the criminal justice system to further the interests of crime victims. See President's TASK ForCE ON Victims of CRIME, FINAL REPORT (1982). In the wake of the Task Force Report, 
numerous states passed state constitutional amendments protecting crime victims including Utah. See Paul G. Cassell, Balancing the Scales of Justice: The Case for and Effects of Utah's Victims' Rights Amendment, 1994 UTAH L. REV. 1373, 1381-82.

As a result of all these victim-related reforms, a new model of criminal procedure has emerged - one that recognizes the rights of crime victims to participate in the process. See generally Douglas E. Beloof, The Third Model of Criminal Process: The Victim Participation Model, 1999 UtAH L. ReV. 289. Victim involvement is appropriate because of the harm that victims have suffered from the crime. The social contract between the citizen and society requires that victims be involved in the process of holding wrongdoers accountable. See id. at 294-95; Richard L. Aynes, Constitutional Considerations: Government Responsibility and the Right Not to be a Victim, 11 PEPP. L REV. 63, 69-73 (1984). Victim involvement is also important to avoid "secondary victimization" - that is, avoiding additional psychological trauma to the victim by perpetuating the subordinate position that the crime itself placed her in. Dean G. Kilpatrick \& Randy K. Otto, Constitutionally Guaranteed Participation in Criminal Proceedings for Victims: Potential Effects on Psychological Functioning, 34 WAYNE L. REV. 7, 19 (1987).

Crime victims' ability to seek court-initiated prosecutions is, of course, one possible step in that direction of active victim involvement. As noted above, see Part II.D, supra, in 1984, Utah's electorate chose to add language into our state's constitution confirming that public prosecutors would be the "primary" method of prosecution - 
leaving room for victims to seek prosecution of those who have harmed them. Thus, the narrow interpretative issue here is not whether article VIII, $\S 16$ should be viewed as a way of replacing elected prosecutor efforts, but rather how it can supplement those efforts. See State v. Woodmansee, 35 A. 961, 961 (R.I. 1896) (public and private prosecution are "additional" and "supplementary," not exclusive of one another).

Against this backdrop of the importance of considering victims' interests in the criminal justice process, a strong reason exists for giving a robust interpretation to Utah's Court-Appointed Prosecutor Provision. It would require remarkable confidence in the infallibility of public prosecutors to believe that a system of public prosecution operates perfectly. Rather than leave completely unreviewable discretion in the hands of government prosecuting agencies, it has long been the policy of Utah (and other states, see discussion below) to provide an opportunity for review of the public prosecutor's decision not to pursue criminal charges.

Public prosecuting offices, no less than other governmental bureaucracies, can make mistakes or, worse, act for improper reasons. It has long been recognized that "[t]he affirmative power to prosecute is enormous, but the negative power to withhold prosecution may be even greater, because it is less protected against abuse." KENNETH Culp Davis, Discretionary Justice: A Preliminary InQuiry 188 (1969). Indeed, "[p]erhaps nine-tenths of the abuses of the prosecuting power involve failure to prosecute ..." Id. at 191 n.2. Precisely because it can go unchecked, prosecutorial discretion to decline to file charges "holds the potential for abuse." Note, Private Challenges to 
Prosecutorial Inaction: A Model Declaratory Judgment Statute, 97 YALE L.J. 488, 490

(1988). Moreover, the exercise of discretion "takes place out of public view - in the hallways of the courthouse in the prosecutors' offices, or on the telephone." James Vorenberg, Decent Restraint of Prosecutorial Power, 94 HARV. L. REV. 1521, 1522 (1981).

In the absence of some way to try to independently seek a prosecution, "crime victims are left with little or no recourse when government prosecutors decide not to pursue a criminal complaint." Michael T. McCormack, The Need for Private Prosecutors: An Analysis of Massachusetts and New Hampshire Law, 37 SUFFOLK U. L. REV. 497, 509-10 (2004). Moreover, without some means for securing the filing of welljustified criminal charges, other rights for crime victims remain entirely unprotected. Utah's Victims' Rights Amendment, for example, promises victims a "right to justice and due process," including the right to be heard on plea agreements and at sentencing. See Utah Const., art. I, § 28(1) \& (1)(b); see also Utah Code § 77-38-4. When a public prosecutor refuses to file well-founded criminal charges, those rights never come into existence. Thus, as Professor Welling has explained, "In jurisdictions that have made the decision to grant victims a participation right at other stages, victim participation in the charging decision is consistent with the current structure and would contribute to a coherent system." Sarah N. Welling, Victims in the Criminal Process: A Utilitarian Analysis of Victim Participation in the Charging Decision, 30 ARIZ. L. REV. 83, 117 (1988). 
This case provides an excellent illustration of the risks lurking in absolute discretion to refuse to file criminal charges. Across this country today (indeed, around the globe), a debate is occurring about whether women who report sexual assaults to law enforcement are taken seriously - a debate reflected in the ubiquitous \#MeToo hashtag used on social media. In these four cases, prosecutors have offered little real explanation for why they chose not to file crime charges against those who raped or sexually assaulted Jane Doe 1, Jane Doe 2, Jane Doe 3, and Jane Doe 4. A typical reason for declining to pursue a case - lack of evidence - simply does not exist here. As recounted above, the investigative law enforcement agencies to whom the four Jane Does reported their attacks assembled evidence providing a strong basis for prosecution and presented the cases for prosecution to the Salt Lake District Attorney's Office. Thus, the Jane Does' cases fit precisely the situation where court-appointed prosecution is most appropriate. As Professor Gittler has explained, "The victim-initiated prosecution could be regarded as a needed and desirable check on prosecutorial charging discretion, insofar as it leads to decisions based upon administrative considerations which neither promote the victim's interests nor serve the purposes of the criminal law and the goals of the criminal sanctioning process." Josephine Gittler, Expanding the Role of the Victim in a Criminal Action: An Overview of Issues and Problems, 11 PePPerdine L. Rev. 117, 158 (1984). Utah's electorate who approved court-appointed prosecution in 1895 - and the electorate who retained such prosecution in 1984 - presumably recognized that victiminitiated prosecutions "may prove useful in trying cases that may otherwise go unnoticed 
by the system, may help relieve the burdens of overworked public prosecutorial offices, and allow the use of expert prosecutors in particularly complex cases ...." Michael Edmund O'Neill, Private Vengeance and the Public Good, 12 U. PA. J. Const. L. 659, $662(2010)$.

\section{B. Victim-Initiated Prosecution Remains the Law in Many States Today.}

Utah is not the only State to have considered how to respond to the problem of prosecutors not filing strong criminal cases. As explained above, see Part II.A, supra, public prosecutors were created only after the birth of this country. While public prosecution has since developed as the main form of criminal prosecution, today many states retain various forms of victim-initiated prosecution or review of public prosecutor decisions. See generally Douglas E. Beloof, Paul G. Cassell, Margaret Garvin \& Steven J. Twist, Victims In CRiminal Procedure 157-224 (4th ed. 2018) (summarizing various forms of victim involvement in prosecution decisions). ${ }^{15}$

${ }^{15}$ Victim-initiated prosecution has also been recognized in the federal system, albeit on a more limited based. Young v. U.S. ex rel. Vuitton et Fils S.A., 481 U.S. 787 (1987), considered the question of whether a federal trial court possessed the inherent authority to appoint private counsel to prosecute several defendants for criminal contempt of a courtordered injunction (rather than requiring the court to refer the matter to the federal prosecuting authorities). Young answered this question in the affirmative. 481 U.S. at 793. Young also considered whether attorneys for the victim could be those prosecutors. Noting that Congress specifically has provided that "each United States attorney, within his district, shall . . prosecute for all offenses against the United States," 28 U.S.C. § 547 (emphasis added), Young concluded that the victim's attorneys were not appropriate prosecutors in that particular case in light of this federal statute. 481 U.S. at 808-09. Thus, Young says little about the state constitutional law issues in play in this case. See Cronan ex rel. State v. Cronan, 774 A.2d 866, 876-77 (R.I. 2001) (finding Young inapplicable in a state case involving Rhode Island private prosecution). 
"Despite widespread belief that such instances of private initiative in the prosecution of crime are extremely rare, the history of the American public prosecution system indicates that this is not so." Juan Cardenas, The Crime Victim in the Prosecutorial Process, 9 HARV. J.L. \& PUB. PoL’y 357, 374 (1986). For example, Professor Moley, writing in 1929, found that the extent of "private" prosecution in the United States was "great and apparently enlarging." R. MOLEY, POLITICS AND CRIMINAL Prosecution 230 (1929). And another commentator, writing in 1955, found that "private prosecutors in fact play an extensive role in law enforcement." Comment, Private Prosecution: A Remedy for District Attorneys' Unwarranted Inaction, 65 YALE L.J. 209, 218 (1955).

Generally speaking, prosecution by a private actor is permitted unless there is a specific statutory prohibition. As we discussed above, the common law plainly authorized private prosecution. See Part II.A, supra. That common law tradition continues unless blocked by legislative enactment, as explained in Ohio v. Ray, 143 N.E.2d 484 (Ohio App. 1956). While no state statute specifically authorized a victim to bring her own prosecution, the Ohio court recognized that "it is common knowledge that the common-law practice (of private prosecution) still prevails, to some extent at least in inferior courts." Id. at 485. The court continued: "[w]e know of no statutory or constitutional reason for prohibiting such practice and, in our opinion, it is well and wise that the policy of the law permits the appearance of private counsel, especially in courts with limited jurisdictions." Id. Small wonder, then, that state statutes may not specify 
victim-initiated prosecution, because such statutes are superfluous to the operation of the common law - although Ohio has recently chosen to codify this general approach in statute. See Ohio Rev. Code $\S 2935.09$ (D) (allowing private citizen to file an affidavit seeking filing of charges). And the common law right to prosecution for private individuals continues to be relied upon today, as the Rhode Island Supreme Court did in affirming a criminal conviction (for domestic violence) obtained by a private prosecutor. See Cronan ex rel. State v. Cronan, 774 A.2d 866, 871 (R.I. 2001) (affirming conviction and noting that "prosecutions based upon complaints filed by private individuals have a pedigree that stretches back into early English law; indeed, they have been described as a principal feature of English criminal law" (citing Blackstone)).

Some states have, however, specifically enacted statutes authorizing prosecution by crime victims. For example, Pennsylvania sets forth in statutory language essentially the same right that Utah provides in constitutional language, allowing for a prosecution if a prosecutor "neglects or refuses" to prosecute. 16 PA. STAT. ANN. § 7710 (emphasis added). Idaho law contains a similar provision. IDAHO CODE ANN. § 19-504; see State v. Murphy, 584 P.2d 1236, 1241 (Idaho 1978) (finding that "Idaho's law provides that a warrant for arrest may be issued upon a complaint filed upon information by a private citizen if the magistrate, after investigation, is satisfied that the offense has been committed").

Many states allow private citizens to prosecute misdemeanors. In New Jersey, a victim can file a misdemeanor criminal complaint and, if the public prosecutor declines to 
pursue the case, "any attorney may appear on behalf of any complaining witness and prosecute the action on behalf of the state or municipality." See State of New Jersey v. Kinder, 701 F. Supp. 486 (D.N.J. 1988) (discussing New Jersey Municipal Court Rule 7:4-4(b) ${ }^{16}$ and rejecting constitutional attack on it) (emphasis added); see also Voytko $v$. Ramada Inn of Atlantic City, 445 F. Supp. 315 (D.N.J. 1978) (violation of defrauding of innkeepers statute). Other states give victims the right to initiate charges in various circumstances. See, e.g., Bradford v. Knights, 695 N.E.2d 1068, 1071 (Mass. 1998) (recognizing that Massachusetts General Laws chapter 218, section 35A, "allow[s] private parties to seek criminal complaints in the case of misdemeanors"); Wash. Crim. Rules for Courts of Limited Jurisdiction 2.1(c) (authorizing citizen complaints); Ala. Code $\S 28-4-314$ (2001) (giving "private parties the right to prosecute violations of laws prohibiting "the evils of intemperance.").

Moreover, in many jurisdictions around the country, victims have the power to challenge the public prosecutor's decision not to bring charges. The most common procedure is to allow victims to present a case directly to the grand jury. ${ }^{17}$ Other states

${ }^{16}$ While the rule has recently been redrafted and renumbered, citizen complaints remain authorized in New Jersey today. See Rules Governing the Courts of the State of New Jersey, Rule 7:2-2(a)(1) (authorizing issuance of a complaint-warrant on the basis of a complaint made by a "private citizen") (available at https://www.njcourts.gov/attorneys/rules.html (visited Sept. 4, 2018)).

${ }^{17}$ See, e.g., State ex rel. Miller v. Smith, 285 S.E.2d 500 (West Va. 1981) (upholding a citizen's state constitutional right to directly report crime to grand jury without public prosecutor interference); Brack v. Wells, 40 A.2d 319 (Md. 1944) (upholding citizen access to the grand jury); King v. Second Nat'l Bank \& Trust Co., 173 So. 498, 499-500 (Ala. 1937) (observing that "[p]ublic policy demands that the citizen, without hazard to himself, may freely bring before the grand jury the fact that a crime has been committed, request an investigation, and furnish such information as he has in aid of the investigation”); State v. Sullivan, 105 So. 631, 633 (La. 1925) (“[a]ny person has a right 
allow victims to approach the grand jury with the court's permission. ${ }^{18}$ Still other states have statutes allowing victims to challenge the public prosecutor's failure to bring charges in this country. See Stuart P. Green, Comment, Private Challenges to Prosecutorial Inaction: A Model Declaratory Judgment Statute, 97 YALE L.J. 488 (1988) ("at least nine states have, or recently had, statutory schemes that potentially enable private persons to challenge prosecutorial inaction"). And in still other jurisdictions, citizens may collect signatures and present a petition within the judicial district to convene a grand jury on the criminal case. See, e.g., Neb. Rev. Stat. § 29-1401. Other jurisdictions have specific statutory provisions for challenging a prosecutor's decision via judicial review. See, e.g., Commonwealth v. Benz, 565 A.2d 764, 767 (Pa. 1989) (courtordered charges filed in homicide case on motion of victim's mother); State v. Unnamed Defendant, 441 N.W. 2d 696 (Wis. 1989) (permitting court to conduct investigation and review and order charges filed pursuant to "John Doe" procedure).

to go before the grand jury and prefer a charge against another"); Tex. Crim. Proc. Code Ann. art. 20.09 ("The grand jury shall inquire into all offenses liable to indictment of which any member may have knowledge, or of which they shall be informed by the attorney representing the State, or any other credible person."); Tenn. Code Ann. § 4012-104 (a)-(c) ("Any person having knowledge or proof of the commission of a public offense triable or indictable in the county may testify before the grand jury."); Watts $v$. Civil Serv. Bd. for Columbia, 606 S.W.2d 274, 282-83 (Tenn. 1980) ("no one may prevent a person from appearing before a grand jury. Indeed, it is his duty to do so if he has evidence of a crime.").

18 See, e.g., In re New Haven Grand Jury, 604 F. Supp. 453 (D. Conn. 1985); In re Petition of Thomas, 434 A.2d 503 (Me. 1981); Colo. Rev. Stat. Ann. § 16-5-204(4)(1) (allowing "any person" to approach "the grand jury); Neb. Rev. Stat. § 29-1410.01 (similar statute to Colorado's); State ex rel. Wild v. Otis, 257 N.W.2d 361, 364-65 (Minn. 1977) (observing that while a private citizen "does not have a right to appear before the grand jury, he is free to attempt to get the grand jury to take action"). 
Outside the United States, numerous common law countries provide private individuals participation rights, including prosecutorial authority, in criminal cases. See Verónica Michel \& Kathryn Sikkink, Human Rights Prosecutions and the Participation Rights of Victims in Latin America, 47 LAW \& SOC'Y REV. 873, 881-82 (2013) (identifying 21 common law countries providing prosecutorial participation or civil actor rights in criminal cases).

Such procedures - in America and around the globe - give lie to any argument that the public prosecutor should be an indispensable prerequisite to the initiation of criminal charges. As Justice Day of the Wisconsin Supreme Court has cogently explained, in this time "when we see interest in 'victim's rights' come to the fore, certainly having one's tormentor brought to justice should be near the rights at the top of any victim's rights program, second only to the right not to be a victim in the first place." State v. Unnamed Defendant, 441 N.W.2d. at 707 (Day, J., concurring). Justice Day concluded that "[c]rime victims should have recourse to the judicial branch when the executive branch fails to respond." Id. Of course, in Utah, victims are constitutionally promised that recourse through the Court-Appointed Prosecutor Provision.

\section{Each of the Four Jane Does Have Presented a Compelling Case for Appointment of a Private Prosecutor.}

Each of the four Jane Does easily satisfies the three-part test described above for obtaining appointment of a private prosecutor under Utah Const., art. VIII, § 16. Specifically, each of the four Jane Does has provided information in this petition establishing: (1) the public prosecutor has failed or refused to prosecute; (2) a prosecution 
is supported by clear probable cause; and (3) the appointment of a prosecutor would be in the interests of justice. We discuss each of the four Jane Does' cases individually in the four following sections.

\section{A. Jane Doe 1 Has Presented an Appropriate Case for the Appointment of a Prosecutor.}

The facts regarding the Jane Doe 1 case have been described above. See Facts, Part I, supra. Given the specific declination letters that she has received - from the Salt Lake County District Attorney's Office (as well as the Attorney General's Office) - it is obvious that the public prosecutor has failed and refused to prosecute.

Jane Doe 1 has also provided clear probable cause for the filing of a rape charge. Based on her report to law enforcement, the only issue is whether the assault was nonconsensual. This Court has emphasized that consent in rape cases is "a fact-intensive, context-dependent question, decided on a case-by-case basis. To determine whether a victim has truly consented, the factfinder must pay close attention to the verbal and nonverbal cues given by the victim and to a wide range of other elements of context." State v. Barela, 2015 UT 22, ๆ 39, 349 P.3d 676, 684. Thus, this Court has instructed that "contextual nuances are ... why, as a general rule, our law has long left the matter of consent in the hands of the jury." Id.

Here, there are ample circumstances from which a jury could reasonably conclude both that Jane Doe 1 had not consented and that Richard Roe 1 was well aware of her lack of consent. For example, the rapid and aggressive nature of the attack, combined with Jane Doe 1's lack of participation in the encounter and physical inability to resist, 
are all facts that, taken together, easily support clear probable cause for a finding of nonconsent. Moreover, while Roe 1 may attempt to argue at trial that Doe's "freezing" led him to believe consent existed, this Court has specifically held that "freezing" is an "excellent example" of something that must be evaluated in context - and by the jury at trial. See Barela, 2015 UT 22, at 939 n.7. Cf. State v. Blake, 2002 UT 113, \12, 63 P.3d 56 (noting that the "vehicles for institutionalized suspicion of rape complainants have typically been ... [legal] requirements, where the focus is shifted to the victim's acts, rather than the defendant's").

Indeed, the facts of the Barela case are quite similar to this one, making clear that a prosecution would likely lead to a conviction. In Barela, victim K.M. "testified that she had not flirted with Barela, and did not say or do anything to suggest she wanted to have sex with him." Id. at 97 . She also testified that she did not physically resist or tell Barela "no"; indeed, she said nothing at all. Instead, she clung to a blanket and "just froze." Id. She said she felt fearful because she was alone, and because the only other person in the massage parlor was a male receptionist. Id. She repeatedly stressed that "everything happened very fast." Id. She elaborated she "checked out," "kind of withdrew," and "was scared." Id. These facts are eerily parallel to Jane Doe 1's facts and make clear that Utah juries have convicted on evidence such as Jane Doe 1 presents.

The District Attorney's Office seemed to rest its non-prosecution decision on outmoded notions that a victim must physically resist to her utmost to establish nonconsent. See generally SuSAN EHRLich, REPRESENTING RAPE: LANGUAGE AND SEXUAL 
CONSENT (2001) (noting that while the "utmost resistance" standard was replaced as a legal construct after the $1950 \mathrm{~s}$, it too often remains a reference for evaluating rape charges in modern times). But in recent decades at least, this Court has made clear that a "resistance" requirement has no place in modern rape law. See State v. Blake, 2002 UT 113, ๆๆ 12-13, 63 P.3d 56 (noting abandonment of resistance requirement in modern rape law). In the year 2018, this Court should send a clear message that (as with the Court of Appeals) it "reject[s] outright [any] suggestion that a victim is responsible for stopping her own sexual assault.” State v. Cady, 2018 App 8, 27 n.8, 414 P.3d 974.

Finally, Doe's physical limitations further support not only probable cause but a prosecution in the interests of justice. Because Jane Doe 1 has a form of muscular dystrophy, she has muscle atrophy, muscle weakness, and disturbances in peripheral sensation. [App. at 3, 309.] As a result, she is physically weak, [App. at 14, 309.] Functionally, she must act slowly and deliberately, including with her speech. [App. at 309.] What strength she does have diminishes rapidly during a sustained effort and she fatigues quickly. [App. at 309.]

Given all these facts, authorizing a prosecution is clearly in the interests of justice. Prosecution will not only insure that Jane Doe 1's abuser is brought to justice, but also help to protect particularly vulnerable persons in Utah. The most recently available data from the U.S. Department of Justice reveals that the rate of victimization for rape and sexual assault against persons with disabilities is more than three times higher than those without. See Bureau of Justice Statistics, U.S. Dep'T of Justice, Crime Against 
Persons with Disabilities, 2009-2015 at 3 (2017). And yet, despite that increased vulnerability, prosecutions for those who abuse the disabled do not appear to be a priority in the criminal justice system. Nancy M. Fitzsimons, Justice for Crimes Victims with Disabilities in the Criminal Justice System: An Examination of Barriers and Impetus for Change, 13 U. St. Thomas L.J. 33, 66 (2016). The reason for this lack of interest appears to be that "[p]ersons with disabilities - the 'victimological others' - do not make an ideal victim within our society or the criminal justice system." Id. Appointing a prosecutor to pursue a case of sexual violence against Jane Doe 1 would be in the interests of justice by helping to secure justice for physically disabled persons within this State.

In sum, Jane Doe 1 amply demonstrates that this Court should appoint a prosecutor under Utah Const., art. VIII, § 16. A proposed charging document to begin the prosecution is attached to this petition. ${ }^{19}$

\section{B. Jane Doe 2 Has Presented an Appropriate Case for the Appointment of a Prosecutor.}

For many of the same reasons as explained for Jane Doe 1, this Court should also appoint a prosecutor to prosecute the sexual assaults committed against Jane Doe 2. She provides a clear and credible account of suffering repeated sexual assaults at the hands of a repeat sex offender. See Facts, Part II, supra. Indeed, Richard Roe 2 used the fact that he was sex offender to coerce Jane Doe 2 into the situation where he could assault her.

19 Because Richard Roe 1 was a juvenile at the time that he attacked Jane Doe 1, the charging instrument is a petition under the juvenile justice provisions of the Utah Code. See Utah Code $\S 78$ A-6-601 et seq. 
Jane Doe 2 was not only broadly coerced, but also specifically coerced. During the sexual attacks, she told Richard Roe 2 to stop, but he refused. Of course, intercourse or other sexual activity that follows withdrawal of consent is rape. See generally Offense of Rape After Withdrawal of Consent, 33 A.L.R.6th 353 (2008 \& 2018 Supp.). And, as a women suffering from cerebral palsy, her ability to resist Roe was obviously impaired. As with Jane Doe 1, the "contextual nuance[s]" surrounding the attacks on Jane Doe 2 should be placed "in the hands of the jury." State v. Barela, 2015 UT 22, ๆ 39, 349 P.3d 676,684 .

In sum, Jane Doe 2 amply demonstrates that this Court should appoint a prosecutor under Utah Const., art. VIII, § 16. A proposed criminal information to begin the prosecution is attached to this petition.

\section{Jane Doe 3 Has Presented an Appropriate Case for the Appointment of a Prosecutor.}

For many of the same reasons as explained for Jane Doe 1 and Jane Doe 2, this Court also should appoint a private prosecutor for Jane Doe 3. The Salt Lake District Attorney's Office has failed and refused to prosecute. See Facts, Part III, supra. Equally clearly, Jane Doe 3 has provided credible evidence of multiple acts of rape - each of which is thus well-supported by probable cause. Id. Thus, as with Jane Doe 1 and Jane Doe 2, proceeding with a prosecution is in the interests of justice, both to hold her rapist accountable and enforce this State's laws against sexual violence.

In addition to the above-detailed compelling reasons for prosecution, an additional reason exists as well: Richard Roe 3 is a prominent law enforcement official in a county 
adjoining Salt Lake County. As a result, an inevitable perceived (if not actual) conflict of interest existed when other law enforcement officials (Salt Lake County prosecutors) decided not to prosecute him. The only way in which the public can have assurance that the matter has been handled appropriately is for this Court to appoint an independent prosecutor to pursue the matter to a resolution in open court proceedings. ${ }^{20}$ The simple fact is that, "[f]or better or worse, most prosecutors may have reason to be concerned about public opinion in high-profile cases" of possible crimes by police officers. Roger A. Fairfax, Jr., The Grand Jury's Role in the Prosecution of Unjustified Police Killings Challenges and Solutions, 52 HARV. Civ. R.-Civ. LiB. L. Rev. 397, 409 (2017). Because of the inevitable suspicion associated with a decision not to prosecute a law enforcement officer where clear probable cause exists, appointing a prosecutor to prosecute Richard Roe 3 is in the interests of justice.

In sum, Jane Doe 3 amply demonstrates that this Court should appoint a prosecutor under Utah Const., art. VIII, § 16. A proposed criminal information to begin the prosecution is attached to this petition.

\footnotetext{
${ }^{20}$ We are not the first to recognize this problem, which has gained salience in recent years as potential crimes by law enforcement officers have been much in the news. Indeed, it might make sense (as some have suggested) to flatly bar local prosecutors from ever making the final decision on whether to file charges against a law enforcement officer: "Automatically removing a local prosecutor spares her from having to balance the public's desire for police accountability and the police officers' indignation at being over-scrutinized, thus preserving the local prosecutor's relations with both her constituency and law enforcement partners." Caleb J. Robertson, Restoring Public Confidence in the Criminal Justice System: Policing Prosecutions When Prosecutors Prosecute Police, 67 EMORY L.J. 853, 867 (2018).
} 


\section{Jane Doe 4 Has Presented an Appropriate Case for the Appointment of a Prosecutor.}

For many of the same reasons as the other Jane Does, Jane Doe 4 has presented a clear case for this Court to appoint a prosecutor. As explained in the fact section above, the District Attorney's Office has rejected not only her plea for a prosecution, but also those of the relevant law enforcement agency. See Facts, Part IV, supra. Probable cause also clearly exists. For example, the anal penetration that Jane Doe 4 alleges during a massage [App. at 123-24] clearly establishes probable cause for a sex offense. Indeed, this is not simple case of two counter narratives, as the later sexual assault examination found a confirming rectal tear. [App. at 202-03.] More than ample probable cause exists for a prosecution to move forward.

In sum, Jane Doe 4 amply demonstrates that this Court should appoint a prosecutor under Utah Const., art. VIII, § 16. A proposed criminal information to initiate the prosecution is attached to this petition.

\section{The Under-Enforcement of Criminal Laws Forbidding Sexual Assault Against Women by Prosecutors Further Warrants Appointment of Prosecutor.}

The appointment of a private prosecutor is warranted not only by the specific facts of each of the Jane Does' cases, but also by the broader pattern of under-prosecution that exists for crimes of sexual assault committed against women and girls. In this Part of the petition, we document the existence of this under-enforcement, both at a national and local level. In light of this under-enforcement, appointment of prosecutors is appropriate to protect not only the values enshrined in the Court-Appointed Prosecutor Provision, but 
also those contained in the Utah's Uniform Operations of Laws Provision, Utah's Equal Rights Provision, and the federal constitution's Equal Protection Clause.

\section{A. Sexual Assault Against Women is a Problem of Staggering Proportions in this Country in General and Utah in Particular.}

Rape and other forms of sexual violence ${ }^{21}$ against women and girls leads to pervasive victimization in the United States in general and Utah in particular. National epidemiological data indicate that $18 \%$ to $25 \%$ of women will be raped or sexually assaulted during their adult lifetimes. REBECCA CAMPBELL, ET AL., THE IMPACT OF Sexual Assault Nurse Examiner Programs on Criminal Justice Case Outcomes: A Multisite Replication Study, Violence Against Women 1, 2 (May 2014). For example, the National Violence Against Women Survey conducted in 1995 and 1996 found that "17.7 million women and 2.8 million men in the United States were forcibly raped at some time in their lives, with 302,091 women and 92,748 men forcibly raped in the year preceding the survey." See Patricia Tjaden \& Nancy Thoennes, Nat'1 Inst. of Justice, U.S. Dep't of Justice, Extent, Nature, and Consequences of Rape Victimization: Findings from the National Violence Against Women Survey, 1 (2006), available at https://www.ncjrs.gov/pdffiles1/nij/210346.pdf. A more recent survey reported that the number of females age 12 or older who experienced "completed, attempted, or threatened rape or sexual violence" are estimated to be about 270,000 in 2010. Michael Planty et al., U.S. Dep't of Justice, Bureau of Justice Statistics, Female

${ }^{21}$ Where possible, the citations in this section identify with specificity the sexual offense(s) at issue in a referenced study. 
Victims of Sexual Violence, 1994-2010, 1 (2013), available at https://www.bjs.gov/ content/pub/pdf/fvsv9410.pdf. See also Staff of Sen. Jud. Comm., Violence Against Women: The Increase of Rape in America 1990, 102d Cong. 1 (1991) (describing the "rape epidemic" in this country).

Sadly, Utah's women and girls suffer horrifically from sexual violence, at rates well above national averages. An important recent report from the Utah Office on Domestic and Sexual Violence found that "[d]omestic and sexual violence are two of the most serious crimes in Utah" and identified significant and long-term physical and psychological health consequences for victims of sexual violence. Utah Office on Domestic \& Sexual Violence, No More Secrets: Utah's Domestic \& Sexual Violence Report 2013 at i (2013), available at https://justice.utah.gov/Violence/ Annual\%20Reports/nms_annualreport_2013.pdf. Another important report from Utah's Commission on Criminal and Juvenile Justice ("CCJJ") found that "[r]ape is the sole Violent Crime Index offense for which Utah's rate rises above that of the nation's average" and that, among the adult Utah women surveyed, about one in three-28.9 percent - reported having been sexually assaulted during their lifetimes. Christine Mitchell \& Benjamin Peterson, CCJJ, 2007 Rape in Utah Survey, 2, 5 (2008), available at https:/justice.utah.gov/Documents/Research/SexOffender/RapeinUtah2007.pdf.

FBI reports document that rape occurs in Utah at a significantly higher rate than the national average. According to the FBI's Uniform Crime Reporting data, the number of rapes in Utah in 2016, as reported by law enforcement agencies, was 49.8 per 100,000 
inhabitants, as comparted to 40.4 nationally. U.S. Dep't of Justice, Federal Bureau of Investigation, 2016 Crime in the United States, Violent Crime, Rape (table 2).

Sexual violence is not evenly proportionated between males and females but is disproportionately concentrated among females. Both national and Utah-specific studies show that females (i.e., women and girls ${ }^{22}$ ) experience significantly higher rates of sexual assault crimes compared to males. For example, one study used data from the National Crime Victimization Survey to examine the prevalence of sexual violence committed against U.S. female residents age 12 or older from 1995 to 2005 and found that only 10 percent of rape and other sexual assault victimizations were perpetrated against men. Michael Planty et al., supra, at 3. Another national survey of adult men and women found that approximately 86 percent of rape and attempted rape victims are women. Tjaden $\&$ Thoennes, supra, at iii, 1, 3; see also U.S. Dep't of Justice, Identifying and Preventing Gender Bias in Law Enforcement Response to Sexual Assault and Domestic Violence, U.S. Dep't of Justice Guidance Document 5 (2015) (citing research showing that "[s]exual assault and domestic violence are crimes that disproportionately impact women, girls, and lesbian, gay, bisexual, and transgender (LGBT) individuals in the United States").

Utah is no exception to this pattern. As the Utah Office on Domestic and Sexual Violence reported (based on Utah Department of Health data collected in 2010), 12.2

${ }^{22}$ Sexual violence research, including research cited in this brief, is generally framed in gendered terms (e.g., "female," "women," "girls"), without clearly differentiating whether these terms exclusively reference persons whose gender was assigned at birth. 
percent of females and 1.2 percent of males in Utah reported experiencing rape or attempted rape in their lifetimes. No More Secrets: Utah's Domestic \& Sexual Violence Report 2013, supra, at 18.

Young women - such as the Jane Does filing this petition - are among the population most at risk for sexual assault crimes. A recent Justice Department report found that "females ages 18 to 24 had the highest rate of rape and sexual assault victimizations compared to females in all other age groups" during the 1995-2013 period. See Sofi Sinozich \& Lynn Langton, U.S. Dep't of Justice, Rape and Sexual Assault Victimization Among College-Age Females, 1995-2013, 1, 5 (2014). Another report found that females ages 12 to 17 (the age range of Jane Doe 1 when she was raped) experienced sexual violence at the rate of 11.2 victimization per 1,000 , and those ages 18-34 experienced sexual violence at the rate of 7 victimizations per 1,000. Michael Planty et al., supra, at 3 . Indeed, one report found that 54 percent of the female victims reported that they experience their first rape or attempted rape before the age of 18 . Tjaden \& Thoennes, supra, at 3, 18. Here again, clear gender disparities exist. For example, the Center for Disease Control and Prevention has highlighted findings from the 2012 National Intimate Partner and Sexual Violence survey and reported that "[a]pproximately $8 \%$ or an estimated 10 million girls under the age of 18 experienced rape or attempted rape while $0.7 \%$ or an estimated 791,000 boys under age of 18 experience either rape or attempted rape. Centers for Disease Control and Prevention, Nat'l Ctr. for Injury Prevention and Control, Fact Sheet on Sexual Violence in Youth 
(2012), available at https://www.cdc.gov/violenceprevention/pdf/

2012FindingsonSVinYouth.pdf. Turning to Utah specifically, Utah girls suffer disproportionately from these attacks, as 78.7 percent of the Utah women who reported victimization were first sexually assaulted before the age of 18 . Mitchell $\&$ Peterson, supra, at 5.

The Jane Does were all attacked by someone they knew to some degree. Their cases are typical, as across the nation the vast majority of sexual assault crimes against women were perpetrated by a non-stranger. See, e.g., Tjaden \& Thoennes, supra, at 21 (observing the 1995-1996 national survey shows almost 83 percent of female victims' perpetrators were current or former intimate partners, current or former dates, boyfriends, and girlfriends); Planty, et al., supra, at 1 (finding "[i]n 2005-10, 78\% of sexual violence involved an offender who was a family member, intimate partner, friend, or acquaintance"). The same pattern of disproportionate violence against women by nonstrangers exists in Utah, as in Utah "[m]ost sexual assaults were committed by male perpetrators who were known to the victims." Mitchell \& Peterson, supra, at 5.

Finally, because two of the Jane Does bringing this petition suffer from physical disabilities, it is important to note that there is a "growing body of research that crime victimization is a serious, persistent, and pervasive problem for people with disabilities." Nancy M. Fitzsimons, PhD, MSW, LISW, Justice for Crimes Victims with Disabilities in the Criminal Justice System: An Examination of Barriers and Impetus for Change, 13 U. St. Thomas L.J. 33, 46-47 (2016). A recent Crimes Against Persons with Disabilities 
Report (2009-2015) estimated that the rate of rape and sexual assaults committed against persons with disabilities was more than three times that for persons without disabilities.

U.S. Dep’t of Justice, Bureau of Justice Statistics, Crime Against Persons with Disabilities, 2009-2015 at 3 (2017). And females with disabilities are victims of sexual assault crimes at higher rates than those without disabilities. See, e.g., Joseph Shapiro, The Sexual Assault Epidemic No One Talks About, NPR (Jan. 8, 2018), https://www.npr.org/2018/01/08/570224090/the-sexual-assault-epidemic-no-one-talksabout (finding " $[t]$ he rate of rape and sexual assault against people with intellectual disabilities is more than seven times the rate against people without disabilities," and the rate for females victims with intellectual disabilities "is about 12 times the rate" against people without disabilities); see also Matthew J. Breiding \& Brian S. Armour, The Association Between Disability And Intimate Partner Violence In The United States, 25(6) AnNals of EPIDEMiology 455 (2015) (similar); R. Amy Elman, Confronting the Sexual Abuse of Women with Disabilities, VAWnet, National Online Resource Center on Violence Against Women, 2-3 (Jan. 2005) (similar).

\section{B. Crimes of Sexual Violence Against Women and Girls Cause Horrific Consequences that Demand the Highest Level of Attention, Including in Utah's Criminal Justice System.}

"Short of homicide, [rape] is the "ultimate violation of self." Coker v. Georgia, 433 U.S. 584, 597 (1977) (plurality opinion) (quoting U.S. Dept. of Justice Law Enforcement Assistance Administration Report, Rape and Its Victims: A Report for Citizens, Health Facilities, and Criminal Justice Agencies 1 (1975)). Victims of sexual 
violence may experience post-traumatic stress disorder (PTSD), depression, substance abuse, and suicidal thoughts or behavior. One meta-study reviewed 37 studies involving over three million male and female participants with history of "sexual abuse" 23 and concluded that there is "an association between a history of sexual abuse and a lifetime diagnosis of anxiety, depression, eating disorders, PTSD, sleep disorders, and suicide attempts." Laura P. Chen, et al., Sexual Abuse and Lifetime Diagnosis of Psychiatric Disorders: Systematic Review and Meta-analysis, 85 MAYo Clin Proc. 619, 625 (July 2010) (emphasis omitted). Another study found "[s]exual assault is a particularly potent predictor of PTSD" while another indicates adult female rape victims have "[1]ifetime prevalence rates of PTSD ... [that] range from approximately 32\% to $80 \%$." Melissa A. Polusny \& Paul A. Arbisi, Assessment of Psychological Distress and Disability After Sexual Assault in Adults, in Psychological Knowledge In Court 97, 98 (Gerald Young et al. eds., 2006). Research by Utah's CCJJ found that, in this State, "[w]omen with a history of sexual assault reported poorer physical and mental health than nonvictims, including increased rates of PTSD and depression.” Mitchell \& Peterson, supra, at 6 .

Sexual violence can also lead to serious physical problems, such as chronic pain, gastrointestinal disorders, unwanted pregnancies, sexually transmitted diseases, migraines

23 The study defined "sexual abuse" to include "rape and all forms of sexual abuse," including, but not limited to, "noncontact exposure of genitalia, threatened sexual violence, and contact involving genitalia and the mouth." 
and other frequent headaches, and cervical cancer. ${ }^{24}$ Another consequence is that sexual victimization clearly leads to an increased risk of being "sexually revictimized." Catherine C. Classen, et al., Sexual Revictimization: A Review of the Empirical Literature, 6 J. TRAUMA, Violence, \& ABUSE 103, 124 (2005) (reviewing approximately 90 empirical studies that examined sexual victimization during childhood, adolescence, or adulthood and finding that "approximately two of three individuals who are sexually victimized are [sexually] revictimized"). When sexual assault is perpetrated against minor-victims, the impacts of childhood victimization can continue into adulthood. See, e.g., Centers for Disease Control and Prevention, Nat'l Ctr. for Injury Prevention and Control, Fact Sheet on Sexual Violence in Youth, supra (highlighting findings from the 2012 National Intimate Partner and Sexual Violence Survey, and stating that sexual violence in youth, "without appropriate trauma-informed interventions, can result in immediate and lifelong consequences, including physical, emotional, behavior, and social challenges, as well as suffering future abuse or continuing the cycle in adulthood by abusing others"); Michael D. De Bellis et al., Neurodevelopmental Biology Associated with Childhood Sexual Abuse, 20 J. ChILd SeXuAl ABuse 548, 549 (2011) (explaining that childhood sexual victimization "can cause disrupted development leading to delays

${ }^{24}$ See, e.g., Centers for Disease Control and Prevention, Sexual Violence: Consequences, https://www.cdc.gov/violenceprevention/sexualviolence/consequences.html; No More Secrets: Utah's Domestic \& Sexual Violence Report 2013, i (2013), available at https://justice.utah.gov/Violence/Annual\%20Reports/nms_annualreport_2013.pdf (identifying physical and psychological health consequences for victims of sexual violence). 
in, deficits of, or failures of multisystem achievements in motor, emotional, behavioral, language, psychosocial, social, and cognitive skills" and these disruptions can persist into adulthood).

\section{Decisions by Prosecutors to Decline to Prosecute Sexual Assault Crimes Disproportionately Harm Women and Girls.}

Despite the widespread prevalence and devastating impacts of sexual violence against women and girls, such crimes are under-prosecuted both nationally and in Utah. The problems begin with the fact that a comparatively low percentage of crimes of sexual violence are ever reported to law enforcement. A commonly reported figure is that "most of the [rape] cases - in fact, over 80 percent of the cases still go unreported." Rape in the United States: The Chronic Failure to Report and Investigate Rape Cases, Hearing Before the Subcomm. on Crime and Drugs, Sen. Jud. Comm., 111th Cong. 27 (2010) (statement of Dean G. Kilpatrick). Indeed, "[r]ape and other forms of sexual victimization" are "among the most severe and underreported crimes in the United States." Patricia L. Fanflick, Victim Responses to Sexual Assault: Counterintuitive or Simply Adaptive?, Special Topics Series, Nat'l Dist. Attorneys Ass'n, at 1 (2007). One comprehensive study found that only 19.1 percent of the women who were raped (or experienced attempted rape) since their 18th birthday reported the crime to the police.

Tjaden \& Thoennes, supra, at 3, 33. Racial disparities also exist, as the rate of reporting for sexual violence is even lower for victims who are women of color. See, e.g., Colleen Murphy, Another Challenge on Campus Sexual Assault: Getting Minority Students to Report It, Chron. Higher EDUC. (June 18, 2015), available at 
https://www.chronicle.com/article/Another-Challenge-on-Campus/230977. And underreporting of sexual violence is pervasive in Utah and, indeed, may be even more pronounced than in other parts of the country. Mitchell \& Peterson, supra, at 6 (finding only 11.8 percent of adult female victims surveyed in Utah reported the sexual assault to the police). This Court, too, has recognized that "women raped by acquaintances, as opposed to strangers, are much less likely to report those rapes to police." State v. Blake, 2002 UT 113, ๆ 14, 63 P.3d 56.

If reporting alone was the problem, interventions to increase accessibility of reporting and responsiveness of law enforcement might be the answer. Even when victims report sexual assault crimes, however, most are never prosecuted. This has long been the reality for victims across the country - and particularly in Utah. See Campbell et al., supra, at 2 ("[d]espite the alarming prevalence of this crime, most sexual assault victims do not report to law enforcement, and of those incidents that are reported, the vast majority will not be prosecuted"). One widely cited study examined data obtained from state criminal justice statistical analysis centers for 1990 and found that " $98 \%$ of the victims of rape never see their attacker caught, tried and imprisoned." See Majority Staff of the Senate Committee on the Judiciary, 102d Cong., The Response to Rape: Detours on the Road to Equal Justice, 2, 57 (1993). Another study reviewed 1995-1996 national survey data and found that only 37 percent of the rapes and attempted rapes against women that were reported to the police resulted in criminal prosecution. Tjaden \& Thoennes, supra, at 3. 
In Utah, it appears that non-prosecution is even more pronounced than in other States. For example, Utah's Commission on Criminal and Juvenile Justice found that among the 11.8 percent of sexual assault crimes reported to the police, charges were filed in 44.3 percent of those cases - producing an overall prosecution rate of just 5.2\%. Mitchell \& Peterson, supra, at 6.

A variety of factors contribute to the low prosecution rate. Recent research reports deep "skepticism of rape accusations" within America's criminal justice system. Deborah Tuerkheimer, Incredible Women: Sexual Violence and the Credibility Discount, 166 U. PA. L. REV. 1, 32 \& n.181 (2017). Part of the skepticism stems from systemic gender-bias. See Deborah Tuerkheimer, Underenforcement As Unequal Protection, 57 B.C. L. REV. 1287, 1312-34 (2016) (discussing the Justice Department's findings of systematic gender-based bias that contributed to the under-investigation and underenforcement of sexual assault crimes against women). Other research shows an acceptance of "rape myths" by prosecutors. See generally Rape Victims' Access to Justice: Understanding and Combatting Pervasive Rape Myths, NCVLI Victim Law Bulletin (Nat'l Crime Victim Law Inst., Portland, Or.), Apr. 2014, available at https://law.lclark.edu/live/files/16725-ncvlivawrape-victims-access-to.

The likelihood of a prosecution is particularly low when the accused perpetrator is a person known to the victim - as is the situation in these four cases. This Court has itself acknowledged a "long held institution-wide distrust of rape victims in cases where they were acquainted with their assailants." State v. Blake, 2002 UT 113, ๆ 11, 63 P.3d 
56. A clear consensus has developed in the scholarly literature that prosecutors are

particularly unlikely to pursue non-stranger rape cases:

Whatever their other disputes, rape-law scholars agree about several fundamental realities. They agree that, for practical purposes, forcible rape is really two crimes. The consensus is that the criminal justice system performs at least reasonably well in dealing with "aggravated" rapes, defined as rapes by strangers, or men with weapons, or where the victim suffers ulterior injuries. With equal unanimity, scholars agree that the justice system often has performed poorly in cases involving rapes by unarmed acquaintances (dates, lovers, neighbors, co-workers, employers, and so on) and in which the victim suffers no additional injuries. Victims are less likely to report these acquaintance rapes ...; [and] if a victim does report it, the police are less likely to believe her [and] prosecutors are less likely to file charges ....

David P. Bryden, Redefining Rape, 3 Buff. CRIM. L. REV. 317, 317-18 (2000) (citations omitted). ${ }^{25}$

\section{The Salt Lake District Attorney's Office Disproportionately Fails to Prosecute Sexual Assault Crimes Committed Again Women and Girls.}

Against this national backdrop of under-prosecution of sexual assault cases alone, the four Jane Does would have a compelling case for appointment of prosecutors. But when one looks at the Salt Lake District Attorney's Office (which was the prosecuting entity that chose not to prosecute their cases) the case is even more compelling. This is the conclusion found in the expert report of one of the nation's leading experts on the

25 See also Cassia Spohn \& Katharine Tellis, Nat'l Criminal Justice Reference Serv., Policing \& Prosecuting Sexual Assault in Los Angeles City \& County: VI-VII (2012), available at https://www.ncjrs.gov/pdffiles1/nij/grants/237582.pdf (discussing problems of underprosecution of non-stranger sexual assault compared to stranger sexual assault); Lisa R. Avalos, Policing Rape Complainants: When Reporting Rape Becomes A Crime, 20 J. GENDER RACE \& JUST. 459, 476-77 (2017) (similar). 
subject. See Utah R. Evid. 702 (authorizing expert opinion evidence). ${ }^{26}$ Dr. Julie Valentine's expert report, and accompanying CV are attached in the appendix. [App. at 228-46 (report); App. at 248-71 (CV).] As shown there, Dr. Valentine has a B.S. degree in Nursing from the University of Arizona, a Masters degree in nursing from the University of Utah, and a Ph.D. in Nursing (emphasis on research and forensic nursing) from Duquesne University. She is certified by the International Association of Forensic Nurses (IAFN) as a sexual assault nurse examiner for adolescent and adult patients (SANE-A). She serves as co-chairperson for the IAFN Research Committee establishing an international forensic nursing research agenda. In addition, she serves as the IAFN Utah Chapter President. Among other distinctions, she has served on the National Institute of Justice's Sexual Assault Forensic Evidence Report Act (SAFER) Working Group to establish national best practice guidelines for sexual assault kits. She has worked as an assistant professor of nursing for Westminster College (2009-11) and Brigham Young University (2011 to current). Further information about Dr. Valentine is found in her attached report and $\mathrm{CV}$, all of which show significant training, experience, and other specialized knowledge in this area. [App. at 248-71.]

${ }^{26}$ Because this petition lies within the original jurisdiction of this Court, this Court should perform, in the first instance, the "gatekeeper" role for assessing expert testimony by Dr. Valentine and the Jane Does' other experts. Utah R. Evid. 702, Advisory Comm. Notes. Under the rules, a proponent of expert testimony need only make "a threshold showing of reliability." Eskelson ex rel. Eskelson v. Davis Hosp. \& Med. Ctr., 2010 UT 59, 12, 242 P.3d 762, 766 (citing Utah R. Evid. 702(b)-(c)). Dr. Valentine's opinions easily meet that requirement, as do the Jane Does' other expert opinions below. 
Dr. Valentine's methodology was to rely on a "Toolkit" developed by the National Institute of Justice (NIJ) to evaluate criminal case outcomes in adult sexual assault cases in which victims received care and evidence collection by sexual assault nurse examiners (SANEs). [See App. at 229 (citing Campbell, R., Greeson, M., Karim, N., Shaw, J., \& Townsend, S., Evaluating the Work of Sexual Assault Nurse Examiner (SANE) Programs in the Criminal Justice System: A Toolkit for Practitioners (U.S. Dep't Justice Document No. 240917) (2013).] She implemented this Toolkit in Salt Lake County in 2013 as an urban site, as explained in detail in her expert report. [App. at 229.] The NIJ toolkit has theoretical and statistical support, reliability, and validity. [App. at 243.]

Dr. Valentine found that in Salt Lake County from 2003 to 2011, in cases in which sexual assault victims reported to law enforcement with intent to prosecute and had a full forensic examination, only 9\% were filed by prosecutors. [App. at 233.] Although prosecution rates of adult sexual assault cases are low nationally, "the findings from Salt Lake County are the lowest reported for an urban site and at the lowest end of the spectrum for all communities." [App. at 233.] Other urban areas report prosecution rates of about $16 \%$ to $18 \%$-- nearly twice as high as Salt Lake County. [App. at 234.]

These figures must be assessed against the backdrop of significant law enforcement screening before sexual assault cases reach the Salt Lake District Attorney's Office. Law enforcement referred only $34 \%$ of cases to the Office for prosecution $-\mathrm{a}$ very significant winnowing, which presumably leads to only the strongest cases being reviewed for prosecution. [App. at 235.] But even after such screening, the Office 
prosecuted only $25 \%$, declining the other $75 \%$ of sexual cases. [App. at 235.] The four Jane Does are thus like most sexual assault victims who have their cases referred by law enforcement agencies to the Salt Lake District Attorney's Office - after the referral, the Office usually declines to prosecute. As Dr. Valentine explains: "The Jane Doe cases outlined within the petition to the Utah Supreme Court are representative of the majority of rape cases reported to law enforcement in Salt Lake County. The law enforcement agencies conduct their investigations prior to referring the cases to the Salt Lake District Attorney's Office with recommendations for criminal charges. Most rape cases, even after police investigations, are rarely prosecuted in Salt Lake County as typified in the Jane Doe cases." [App. at 243.]

Dr. Valentine also collected data regarding the victims in the sexual assault cases, focusing on two years of the study: 2010 and 2011. It appeared that these data were similar from year-to-year, as a data base from 2012 to 2016 in eight Utah counties showed similar results. [App. at 244.] In Salt Lake County from 2010 to 2011, 95\% of the sexual assault victims in the study were female [App. at 240] - like the four Jane Does. Also, $75 \%$ of the victims were below the age of 34 years [App. at 241] - again, like the four Jane Does. Also, $56 \%$ of the victims were assaulted by acquaintances [App. at 241] - again, like the four Jane Does. Also, $80 \%$ of the victims had physical injuries and $69 \%$ had genital injuries. [App. at 244.] Finally, the data indicated that sexual assault perpetrators often target vulnerable individuals and those less likely to report and to be believed. [App. at 242.] 
Interestingly, Dr. Valentine's study has been replicated by another study. [App. at 243.] One of Utah's most respected media sources - KSL television - was contacted by a rape victim frustrated that her attacker was not being prosecuted, even though she promptly called the police and had a rape kit collected. Mike Headrick \& Tania Mashburn, Data Reveals Few Utah Rape Cases Prosecuted, Nov. 13, 2014, available at https://www.ksl.com/?sid=32340680\&nid=1171. KSL investigators researched the issue over many months, collecting data from July 1, 2009, through December 31, 2013. During that time, 2,319 forcible rapes were reported to Salt Lake County police. Of those, only 760 were sent to the District Attorney's Office to be screened for prosecution, which "means two thirds of those [reported rape cases] went nowhere." Id.

Once cases were reported to the District Attorney's Office, during the five-year period, the office declined more than 500 forcible rape cases while prosecuting only about 200 - a prosecution rate of about $28 \%(200 \div 700)$. Id. Ultimately, of these cases it prosecuted, the Office won about $60 \%$, meaning that the Office obtained a conviction in only about $5.5 \%$ of all forcible rape cases reported. Id. According to Holly Mullen, then-Director of the Rape Recovery Center in Salt Lake City, it appeared as though the District Attorney's Office was only taking cases where they knew that they would win: "[The victims] feel a complete lack of respect. They feel a complete lack of understanding and cynicism and concern about where is this American justice?" Id.

When asked about these statistics and whether the Office only prosecuted socalled "slam dunk" cases, the District Attorney stated, "If that is the way historically 
we've done business, then that's something we should not be doing. Those cases where there is a victim, there is evidence, there is probable cause, but there is not the certainty of conviction, we should not shy away from those." Id. (emphasis added). The District Attorney went on to admit that "I think we have sometimes shied away from that to our own fault." Id. The District Attorney concluded rape victims "deserve better justice. And we can always do more for them." Id.

Finally, it seems likely that the problem of under-prosecution may only be increasing in Salt Lake County. In the wake of the \#MeToo movement, there has been a significant spike in cases of sexual assault being reported to the Rape Recovery Center (located in Salt Lake County). From the September 2016 to August 2017, the Rape Recovery Center served 1,009 sexual assault survivors and responded to 451 calls at Salt Lake County hospitals for rape kit exams. The \#MeToo movement began trending in October 2017, and since then (from September 2017-August 2018), the Center served 1,720 survivors and responded to 626 calls for exams. Ginna Roe, One Year After \#MeToo Movement Started, Salt Lake Sees Spike in Sexual Assault Reports, Sept. 26, 2018, https://kutv.com/news/local/one-year-after-metoo-movement-started-salt-lake-seesspike-in-sexual-assault-reports. That is a 70\% increase in sexual assault reports in a single year - a dramatic increase in reporting that, so far as we are aware, has not been matched by a proportionate significant increase in prosecutions. 


\section{E. Prosecutors' Use of a “Convictability" Standard Leads to Systemic Credibility Discounting of Women and Girls and Reliance on "Rape Myths."}

Prosecutors can file criminal charges when they have probable cause to do so. But prosecutors around the country, including those in Salt Lake County, often employ a "convictability" standard in filing sexual assault cases. Cf. Lisa Frohmann, Constituting Power in Sexual Assault Cases: Prosecutorial Strategies for Victim Management, 45 SoCIAL ProbS. 393, 395 (1998) (reporting that "[t]ypically, prosecutors use the standard of convictability to account for their case filing decisions"). Indeed, in its declination letter to Jane Doe 1, the District Attorney's Office described as a "principle factor" in its decision "the probability of conviction." [App. at 314.] The Office told Jane Doe 1 that it believed her statement that she had been raped, but nonetheless decided the "fact-finder is unlikely to convict [Richard Roe 1] ...." [App. at 17,314.]

As with other many other prosecutors, the Salt Lake District Attorney's Office appears to prosecute so few sexual assault cases because it is using an extreme "convictability" standard in making its prosecution decisions. This approach leads to the systemic credibility discounting of women and girls who have been the victims of sexual assault, as well as reliance on "rape myths" about females who have been assaulted.

An important recent article by Professor Deborah Tuerkheimer of Northwestern University Pritzker School of Law summarizes the available research and explains how prosecutors can unfortunately move to a low prosecution rate. See Deborah Tuerkheimer, Incredible Women: Sexual Violence and the Credibility Discount, 166 U. PA. L. REV. 1 (2017). As Professor Tuerkheimer reports, credibility is central to the legal treatment of 
sexual violence, as epitomized by the iconic "he said/she said" contest. Id. at 3 . Victims who present allegations of sexual violence to prosecutors do not fare well in these contests. Over time, skepticism of rape allegations has remained entrenched in the criminal justice system while migrating from formal legal rules to informal practices that achieve much the same result - the dismissal of women's reports of sexual violation. Id. This "credibility discounting" is the dominant feature of the criminal justice system response to rape. $I d$. In particular, "credibility discounting" is an unwarranted failure to credit an assertion where this failure stems from prejudice. Id.

This convictability standard requires prosecutors to "endeavor to predict how jurors would likely evaluate the proof at trial, including the credibility of the [sexual assault victim].” Tuerkheimer, supra, 166 U. PA. L. REV. at 38. While this standard appears to be the one that prosecutors (such as those in the Salt Lake District Attorney's Office) employs in practice, this convictability "inquiry in not generally sanctioned." Id. For example, the American Bar Association has promulgated standards for prosecutors, which this Court has found informative in other cases. See, e.g., State v. Span, 819 P.2d 329, 336 n.3 (Utah 1991). The ABA standards specifically indicate that "[a] prosecutor may file and maintain charges even if juries in the jurisdiction have tended to acquit persons accused of the particular kind of criminal act in question." AM. BAR ASS'N, Criminal Justice Standards for the Prosecution Function, Standard 3.4(c) (4th ed. current through 2018). 
In light of this guidance, "[e]very prosecutor must closely evaluate the competing interests involved in protecting the human rights of all citizens regardless of the ingrained prejudices that may attach to female victims." Tamara F. Lawson, A Shift Towards Gender Equality in Prosecutions: Realizing Legitimate Enforcement of Crimes Committed Against Women in Municipal and International Criminal Law, 33 S. ILL. U. L.J. 181, 193-94 (2009). With regard to sexual assault cases in particular, prosecutors should not decline to pursue such cases merely because "they are more difficult and less 'winnable' cases. Juries in . . . sexual assault cases have been known to unfairly blame the victim(s) for being raped or beaten. In other words, jurors vote to acquit defendants in order to express their contempt for the victim, instead of because their belief in the defendant's innocence." Id. Prosecutors must challenge these unfair stereotypes, not accept them.

To be sure, it may be difficult to determine who is discounting the credibility of sexual assault victims. As Professor Tuerkheimer explained, "we cannot tell who precisely is wronging the [victim] by discounting her credibility - the prosecutor or the imagined factfinder. ... [But] [e]ven if this reliance is genuine or correct, it results in systemic credibility discounting." Tuerkheimer, supra, 166 U. PA. L. REV. at 39.

This credibility discounting both results from and perpetuates the use of "rape myths." Credibility discounting by prosecutors draws on a stock of narratives that "incorporate[] stereotypes of real crimes and credible victims." Cassia Spohn, Dawn Beichner \& Drika Davis-Frenzel, Prosecutorial Justification for Sexual Assault Case 
Rejection: Guarding the “Gateway to Justice”, 48 Soc. ProbS. 206, 208 (2001). In other words, "framed by an inquiry into how the archetypical juror would assess the [victim's] account, prosecutorial decision-making [under a convictability standard] transposes the widespread acceptance of rape myths into a legitimate rationale for declining to pursue charges.” Tuerkheimer, supra, 166 U. PENN. L. REV. at 40.

Against this backdrop, a prosecutor's decision not to charge a defendant may reflect not only his or her own discounting of victim credibility; it may also anticipate discounting by potential jurors - what Professor Tuerkheimer describes as "anticipatory discounting." Id. at 38. As she explains, "Prosecutorial charging in sexual assault cases is inexorably linked to concerns - whether well founded or not - that jurors will downgrade the [victim's] credibility." Id.

The existence of facts in the Jane Does cases on which rape myths could be founded can be established through an expert evaluation of the four cases at issue here. Attached to this petition is the expert report of Julie Ann Melini, MS, APRN, SANE-A, SANE-P. [App. at 272-79.] She has been a nurse for more than 35 years and is currently the Clinical Director for Wasatch Forensic Nurses (WFN) (formerly known at Salt Lake Sexual Assault Nurse Examiners). [App. at 272.] In that capacity, she is responsible for training and overseeing more than twenty registered nurses who provide forensic medical exams for sexual assault victims at hospitals throughout Salt Lake and Utah Counties. [App. at 272.] She also works with community partners for WFN, including law enforcement officers and prosecuting attorneys, and has previously served as an expert 
witness on subjects related to her experience with sexual assault victims. [App. at 272-

73.] Her CV provides additional qualifications. [App. at 282-86.]

Ms. Melini provides her well-founded expert opinion regarding "rape myths," explaining that they are "stereotypical, prejudicial, or false beliefs about rape, rape victims, or rapists that are generally untrue but are accepted and believed by society." [Id. at 273 (citing K.G. Weiss, "Boys Will Be Boys" and Other Gendered Accounts: An Exploration of Victims' Excuses and Justifications for Unwanted Sexual Contact and Coercion, 15 Violence Against Women 810 (2009)).] Of particular relevance to this case, Ms. Melini identifies four common "rape myths":

1. Sexual assault victims do not know the assailant;

2. Sexual assault victims will forcefully resist their assailant;

3. Sexual assault victims will have significant physical and/or anogenital injury; and

4. Sexual assault victims will immediately report the crime.

[App. at 273.] Ms. Melini provides citations to academic research and other reasons for concluding that each of these four purported facts are "myths," which contribute to assailants not being held accountable for their actions. [App. at 273-76.]

Ms. Melini then identifies the presence of a number of these myths in each of the four cases that the Jane Does present through their petition. [App. at 276-78.] Ms. Melini explains, for example, that Jane Doe 1's account of being frozen by her fear, which is consistent with a "freeze" or "comply" response that is very common for victims of sexual assault. [App. at 275.] Jane Doe 2 similarly was groomed so that Richard Roe 2 could coerce her into sexual contact. [App. at 277.] Jane Doe 3 was coerced by 
Richard Roe 3's use of fear. [App. at 277.] And Jane Doe 4 similarly froze when assaulted by Richard Roe 4, once again a "normal response to sexual assault." [App. at 277.]

\section{F. Failure to Appoint a Prosecutor to Pursue the Well- Founded Sexual Assault Cases of Jane Doe 1, Jane Doe 2, Jane Doe 3, and Jane Doe 4 Will Lead to Institutional Betrayal of these Victims.}

An additional reason for the Court to appoint a prosecutor is to avoid what is best described as "institutional betrayal" of the victims. Annexed to this petition is the expert affidavit of Lecturer Nicole Bedera, who teaches a course on sexual violence at Westminster College and is a leading researcher on how organizations and institutions impact sexual assault survivors' experiences of sexual violence. [App. at 287-93 (report); App. at 294-99 (CV).] As Bedera clearly explains, institutional betrayal is defined in the relevant academic literature as "institutional action and inaction that exacerbate the impact of traumatic experiences." [App. at 288 (citing Carly Parnitzke Smith \& Jennifer J. Freyd, Dangerous Safe Havens: Institutional Betrayal Exacerbates Sexual Trauma, 26 Journal of Traumatic Stress 119 (2013)).] As Bedera describes, "Among these actions and inactions are minimizing the severity of a victim's experience, refusal to take proactive steps in preventing or addressing victimization, and responding inadequately to claims of trauma. Institutional betrayal is intensified when the abuse itself takes place in the context of the same institution tasked with responding to abusive behavior, including the criminal justice system.” [App. at 288 (citing Carly Parnitzke Smith \& Jennifer J. Freyd, Institutional Betrayal, 69 AMERICAN PSYCHOLOGIST 575-587 (2014)).] 
To be clear, institutional betrayal is more than mere negative feelings toward an organization a victim hoped would help her. [App. at 288.] Rather, the betrayal compounds and creates trauma - a trauma so intense that researchers regularly refer to maltreatment by organizations tasked with serving sexual assault survivors as "the second rape.” [Id. at 288 (citing Lee Madigan \& Nancy C. Gamble, The Second Rape: Society's Continued Betrayal of the Victim (1991)).] While seeking and receiving effective resources following an instance of sexual assault can promote healing and reduce the risk of long-term traumatic effects, victims who encounter maltreatment or negligence by institutional actors tasked with helping them are at higher risk of severe traumatic symptoms. [App. at 288 (citing Courtney E. Ahrens, Giannina Cabral \& Samantha Abeling, Healing or Hurtful: Sexual Assault Survivors' Interpretations of Social Reactions from Support Providers, 33 PSYCHOLOGY OF WOMEN QUART. $81-94$ (2009)).] This is not simply a theoretical conclusion, as in two separate studies, institutional betrayal experienced by sexual assault victims was correlated with anxiety, depression, sleep problems, sexual problems, and dissociation. [App. at 288 (citing Carly Parnitzke Smith \& Jennifer J. Freyd, Insult, Then Injury: Interpersonal and Institutional Betrayal Linked to Health and Dissociation, 26 Journal of AGgression, MALTREATMENT \& TRAUMA 1117-1131 (2017), Smith \& Freyd 2013, supra).]

Bedera has also reviewed the four cases described in this petition. It is her expert opinion that each of the Jane Does encountered treatment by the criminal justice system that amounts to institutional betrayal. [App. at 289-90.] By refusing to prosecute cases 
with probable cause, the prosecutors "minimized the severity of the Jane Does' experiences, refused to take proactive steps in responding to their victimization, and responded inadequately to their claims of trauma.” [App. at 289.] Further, the inaction by the prosecutors likely created particularly intense trauma for the four Jane Does because of the length of their engagement with the criminal justice process, including their cooperation during forensic exams and police interviews, which can be emotionally taxing for sexual assault victims. [App. at 289 (citing Shabna L. Maier, "I Have Heard Horrible Stories ... ": Rape Victim Advocates' Perceptions of Revictimization of Rape Victims by the Police and Medical System, 14 Violence Against Women 786 (2008)).] Bedera also concludes, based on the scientific literature on institutional betrayal, that in her expert opinion each of the Jane Does are at a greater risk for long-term traumatic symptoms as the result of the institutional betrayal they have endured, including anxiety, depression, sleep problems, sexual problems, and dissociation. [App. at 290.]

To be clear, the Jane Does are not asking that the Court authorize appointment of a prosecutor in this case simply to assuage their feelings. As described above, these cases all are supported by a very strong factual basis amounting to more than clear probable cause. Against that backdrop, this Court should consider the far greater stakes at issue for the Jane Does - specifically, reducing the risk of long-term traumatic systems. On this dimension, sexual assault cases may stand on somewhat different footing than other kinds of criminal cases. Given the strong underlying factual support for prosecutions 
here, the Court can readily determine that it is in the interests of justice to move forward to avoid institutional betrayal.

\section{G. In Light of the Foregoing Facts, It Is in the Interests of Justice for the Court to Appoint a Prosecutor for the Jane Does.}

As explained in Part VI, supra, even focusing just on the individual facts of each case, it is in the interests of justice to appoint a prosecutor for each of the four Jane Does. But the systemic problems just discussed in this section also support the conclusion that it is in the interests of justice to appoint a prosecutor for each of the Jane Does under Utah Const., art. VIII, § 16. For example, appointing a prosecutor will address the widespread problem of sexual assault in Utah (Part VII.A, supra) as well as the horrific consequences of sexual assault crimes that demand attention (Part VII.B, supra). Appointing a prosecutor will also obviously address the under-prosecution of sexual assault crimes against women and girls, both as reflected in national statistics (Part VII.C, supra) and Salt Lake County statistics (Part VII.D, supra). The appointment will also fight the problem of the credibility discounting of women and prosecutorial reliance on "rape myths" to allow sexual assaults to go unpunished (Part VII.E, supra). Appointing prosecutors will also prevent institutional betrayal of the Jane Does (Part VII.F, supra). For each of these reasons individually - and collectively - this Court should appoint prosecutors for the crimes committed against the Jane Does. 
H. In Light of the Foregoing Facts, The Uniform Operation of Laws Clause, Utah Constitution, Article I, Section 24, and the Equal Rights Provision, Utah Constitution, Article IV, Section 1, and the Utah Victims' Rights Amendment, Article I, Section 28, Require Appointment of a Prosecutor for the Jane Does.

Appointment of prosecutors for the Jane Does is also required by the conjunctive operation of three important provisions in the Utah Constitution: The Uniform Operation of Laws Clause, Utah Const., art. I, § 24; the Equal Rights Provision, Utah Const., art. IV, $\S 1$; and the Utah Victims' Rights Amendment, Utah Const., art. I, § 28. The Uniform Operation of Law Clause provides that "[a]11 laws of a general nature shall have uniform operation." The Equal Rights Provision provides that "[b]oth male and female citizens of this State shall enjoy equally all civil, political and religious rights and privileges." The Utah Victims' Rights Amendment provides that to "preserve and protect victim's rights to justice and due process, victims of crimes have the[] right, as defined by law, ... to be treated with fairness, respect, and dignity ...." Given the gender disparities and other problems identified in this Part, failure to appoint prosecutors for the Jane Does would violate these three constitutional provisions severally and collectively.

Turning first to the Uniform Operation of Laws Clause, even though the provision is the State's analogue to equal protection under federal law, this Court's "construction and application of Article I, $\S 24$ are not controlled by the federal courts' construction and application of the Equal Protection Clause.” State v. Drej, 2010 UT 35, ๆ 33, 233 P.3d 476. Indeed, the Uniform Operation of Laws Clause is "at least as exacting" as its 
federal counterpart and may, "in some circumstances, [be] more rigorous than the standard applied under the federal constitution.” Gallivan v. Walker, 2002 UT 89, ๆ 33, 54 P.3d 1069.

The Court has explained that the "most notable of these differing legal consequences" between federal and state constitutional law "is that article I, section 24 demands more than facial uniformity; the law's operation must be uniform.” Drej, 2010 UT 35, ๆ 33 (citing Gallivan, 2002 UT 89, \37 (emphasis added)). Thus, as this Court recently explained with regard to such state constitutional provisions, "Historically, uniform operation provisions were understood to be aimed not at legislative classification but at practical operation." State v. Canton, 2013 UT 44, ๆ 34, 308 P.3d 517, 524 (emphasis in original). Thus, as originally understood, the Clause was designed to require "consistency in application of the law to those falling within the classification adopted by the legislature ...." Id.

In this particular case, however, Utah's Uniform Operation of Laws Clause must not be read in isolation, but in conjunction with Utah's Equal Rights Provision promising equal rights to women. This conjunctive reading is important to avoid too narrow an application of the Uniform Operation of Laws Clause here. While this Court has recently reaffirmed the caselaw surrounding the Uniform Operation of Law Clause that makes it a "miniature equal protection clause," this Court has also suggested (in dicta) that the historical focus of these types of clauses, at least in some contexts, was not "to seek equal protection of the laws but rather [to] guard against discrimination in favor of a minority." 
State v. Canton, 2013 UT 44, 934 n.7, 308 P.3d 517, 525 (citing G. Alan TARR, Understanding State Constitutions 198 (1998)). But Professor Tarr's reference was to uniformity provisions that "for the most part antedated the Fourteenth Amendment, with its emphasis on protecting minorities against majoritarian abuse." TARR, supra, at 198. Of course, Utah's Uniform Operation of Law provision was drafted well after the Fourteenth Amendment and should be understood in that context of the need to protect equal rights for minorities.

Even more important, Professor Tarr emphasized the need to acknowledge the importance of state constitutional "guarantees of gender equality." Id. Unlike the United States Constitution, which as initially drafted excluded women from the electoral process, the Utah Constitution was specifically designed not only to enfranchise women but also much more broadly to extend gender equality as to all civil and political rights. See generally Jean Bickmore White, Woman's Place Is in the Constitution: The Struggle for Equal Rights in Utah in 1895, UTAH HIST. Q. 344 (fall 1974). Indeed, even before the drafting of the Utah Constitution, Utah women had been enfranchised by an act of the territorial legislature, voting from 1870 to 1887 . That right of women state citizens was stripped way by federal congressional action in Washington, D.C., with the passage of the Edmunds-Tucker Act. See Thomas G. Alexander, An Experiment in Progressive Legislation: The Granting of Women Suffrage in Utah in 1870, UTAH HIST. Q. 8 (Winter 1970). But when the initiative for addressing these gender issues returned to this State, leaders in the women's suffrage movement were determined that Utah's Constitution 
should broadly protect equal rights for women. Thus, on the eve of the drafting of Utah's

Constitution, Susan B. Anthony wrote to the women of Utah, explaining: "Now in the formative period of your constitution is the time to establish justice and equality to all people. That adjective 'male' once admitted into your organic law, will remain there." White, supra, at 345 (citing WOMEN's EXPONENT, 23 (Aug. 1 and 15, 1894), 169).

During Utah's Constitutional Convention, the plight of women was specifically equated with the plight of the newly-freed slaves (strongly protected, of course, by the Fourteenth Amendment). For example, Delegate Andrew Anderson explained that:

Millions of ignorant slaves have been admitted to the right of suffrage ... and yet why hesitate to grant our mothers, our wives and our sisters the rights of suffrage, most of whom are native born, many are property owners and well educated, and all are most vitally interested in the welfare of the government, in the principles of liberty and the perpetuation of the same.

Proceeding of the Utah Constitutional Convention, 1:420-28 (quoted in White, supra, at $356)$.

Ultimately the Convention voted to enshrine equal rights for women. Utah's Constitution could not be clearer on this point. Utah Const., art. IV, $\S 1$ directly provides not only for equal voting rights (i.e., "[t]he rights of citizens of the State of Utah to vote and hold office shall not be denied or abridged on account of sex"), but much more broadly that "[b]oth male and female citizens of this State shall enjoy equally all civil, political and religious rights and privileges" (emphasis added).

This important second sentence - the Equal Rights Provision - has been little discussed by Utah's courts. But this Court has briefly described it as a "clear and 
comprehensive statement in our foundational law [that] correlates with the purpose that there shall be no discrimination based on sex.” Kopp v. Salt Lake City, 29 Utah 2d 170, 172, 506 P.2d 809, 810 (1973). And this Provision has important implications in this case, through its interplay with the Uniform Operation of Laws Clause and Utah's Victims' Rights Amendment.

The Jane Does here are not challenging the statutory language of Utah's sexual assault provisions, which on their surface may appear to be written in gender neutral terms. Accordingly, this Court's three-part analysis of "classifications" created by the statutory text is unnecessary. Cf. State v. Roberts, 2015 UT 24, ๆๆ 40-41, 345 P.3d 1226 (analyzing classifications created by statute). Instead, the Jane Does challenge the laws' “practical operation," Canton, 2013 UT 44, \ 34 (emphasis in original), and particularly how they operate in the hands of local prosecutors.

It does not appear that this Court has had occasion to consider a challenge to law enforcement or prosecuting practices under Utah's Uniform Operation of Laws Clause. But given that the Clause is "at least as exacting" as the federal equal protection clause, Spencer v. Utah State Bar, 2012 UT 92, \ 26, 293 P.3d 360, 368, federal precedents will serve to demonstrate a floor below which state law enforcement and prosecuting agencies cannot go. Federal precedents recognize that while "there is no right to state protection against madmen or criminals, there is a constitutional right . . . to have police services administered in a nondiscriminatory manner - a right that is violated when a state actor denies such protection to disfavored persons." Elliot-Park v. Manglona, 592 F.3d 1003, 
1007 (9th Cir. 2010) (cleaned up); see also DeShaney v. Winnebago County Dep't of Soc. Servs., 489 U.S. 189, 197 n.3 (1989) ("The State may not, of course, selectively deny its protective services to certain disfavored minorities without violating the Equal Protection Clause.”); Estate of Macias v, Ihde, 219 F.3d 1018, 1019, 1028 (9th Cir, 2000) (in case alleging "inferior police protection on account of status as a woman, a Latina, and a victim of domestic violence," holding that there is an equal protection right to have law enforcement services administered in a nondiscriminatory manner). ${ }^{27}$

For purposes of federal constitutional review, gender is a suspect class necessitating heightened scrutiny. City of Cleburne, Tex. v. Cleburne Living Ctr., 473 U.S. 432, 440 (1985). The previous decisions from this Court applying the Utah Uniform Operations of Law Clause have simply assumed that federal equal protection standards apply, while "reserving the right to depart from those standards in an appropriate case in the future." State v. Canton, 2013 UT 44, $₫$ 36, 308 P.3d 517. This Court has noted that previous cases have not provided the required specialized briefing necessary to develop

${ }^{27}$ It is important to emphasize that the Jane Does are not, in this petition, seeking money damages from prosecutors or other state actors. Accordingly, the doctrine of prosecutorial immunity recognized by this Court in decisions such as Jensen ex rel. Jensen v. Cunningham, 2011 UT 17, $\uparrow 52,250$ P.3d 465, is simply not in play. The doctrine rests on the premise that imposing financial liability on prosecutors (or others acting in a similar capacity) will render them unable to render disinterested decisions. See, e.g., Parker v. Dodgion, 971 P.2d 496, 499 (Utah 1998). Judicial appointment of a prosecutor to independently pursue a viable criminal case does not pose any threat to disinterested decisionmaking by public prosecutors. Because immunity doctrines are not at issue in this petition, the Jane Does do not discuss recent judicial opinions and scholarship- calling such immunity doctrines into question. See, e.g., Ziglar v. Abbasi, 137 S. Ct. 1843, 1869 (2017) (Thomas, J., concurring) (writing separately to express "my concerns about our qualified immunity precedents"); William Baude, Is Qualified Immunity Unlawful?, 106 CAL. L. REV. 45 (2018). 
independent state constitutional doctrine. Id. The Jane Does in this case will provide that briefing and, specifically, demonstrate that the Utah Constitution - and particularly the conjunction of the Uniform Operation of Laws Clause, the Equal Rights Provision, and Utah's Victims' Rights Amendment - requires in the particular setting of this case not merely the federal "intermediate" scrutiny of gender discrimination, but (at a minimum) the much-more-difficult-to-satisfy "strict" scrutiny that federal law deploys for racial discrimination.

Interpretation of Utah's Equal Rights Provision must begin with the fact that article IV, $\S 1$ contains two sentences. The first sentence - about the right to vote and hold officer not being denied on account of sex - is the one that seems to have attracted the most attention. But the second provides a very broad command that women "shall enjoy equally all civil, political and religious rights." Against the backdrop of the history described above, that broad provision should not be read as merely providing some sort of ill-defined "intermediate" scrutiny of general-classifications, but rather, at a minimum, "strict" scrutiny - the same sort of scrutiny that the newly-freed slaves were provided in the Fourteenth Amendment to the U.S. Constitution. Indeed, the Provision is best read as requiring absolute equality that not even strict scrutiny can satisfy. Nothing else would honor the textual command of insuring women the opportunity to "enjoy equally" all rights civil, political, and religious.

Other states have reached similar conclusions with similar gender equality provisions in their state constitutions. For example, in Rand v. Rand, 374 A.2d 900 (Md. 
Ct. App. 1977), the Maryland Court of Appeals, surveyed various state provisions, noting that some provisions allowed gender discrimination. See id. at 904 (noting that La. Const., art. I, $\S 3$ forbids only "unreasonable" discrimination based on sex). But the Maryland provision - providing that "[e]quality of rights under the law shall not be abridged or denied because of sex" - admitted no such possibility. See id. at 904-05 ("the broad, sweeping, mandatory language of the amendment is cogent evidence that the people of Maryland are fully committed to equal rights for men and women").

Similarly, Washington has a broad state constitution provision promising that "[e]quality of rights and responsibility under the law shall not be denied or abridged on account of sex." The Washington courts have interpreted this provision as barring any discrimination on account of gender. See, e.g., Darrin v. Gould, 540 P.2d 882, 890 (Wash. 1975) (concluding that such equality provisions "may not be qualified in the manner that 'suspect classification' or 'fundamental interest' doctrines allow”).

We acknowledge that this strong interpretation of the Provision might appear to conflict with an earlier decision of this Court more than one hundred years old: Salt Lake City v. Wilson, 46 Utah 60, 18 P. 1104, 1107 (Utah 1915), upholding a road poll tax of \$2 or in-kind road work made applicable to men but not to women. However, this Court's rationale was that payment of the tax was "neither a political, religious, or other civil right or privilege." Id. Thus, the Provision was, at least according to this Court, not directly at issue. Moreover, this Court should disavow the rationale it offered in 1915 in support of this conclusion. This Court argued that "[s]urely one need not at this day and 
age point out the physical differences that exist between the sexes, nor dwell upon the reasons why females, in the nature of things, cannot respond to all the demands of the state." Id. Moreover, reasoned this Court, "[i]t is a matter of general knowledge that man, during his active career, is the breadwinner for the family, and that upon him must fall the direct burden of discharging the public duties, and especially so when physical exertion and strength are required." Id. This reasoning should be explicitly overruled as an outmoded decision. ${ }^{28}$

Women and girls in Utah do not equally enjoy the "civil right" of having prosecutors enforce the laws against sexual violence. As explained above, as currently applied, the laws against sexual violence are under-enforced in a way that disadvantages women and girls. And this underenforcement can lead women and girls to enjoy lessthan-equal protection in their daily activities, as they are pressured to take steps that men and boys are not required to take. $C f$. Nicole Bedera \& Kristjane Nordmeyer, "Never Go Out Alone": An Analysis of College Rape Prevention Tips, 19 SeXuality \& CUlture 533 (2015) (noting that colleges provide sexual assault prevention messages to women such as women should never be alone and there are no safe places for women). Indeed, the fact that women are expected to alter their lives to avoid being sexually attacked is so pervasive that it permeates many routine activities. See, e.g., Collin Gossel, Women Are

${ }^{28}$ This Court has similarly not hesitated to overrule poorly-reasoned decisions reflecting outdated gender stereotypes. For example, while this Court at one point recognized a gender-based preference in child custody cases, see, e.g., Cox v. Cox, 532 P.2d 994, 996 (Utah 1975), later decisions concluded that such a preference would violate the Equal Rights Provision. See, e.g., Pusey v. Pusey, 728 P.2d 117, 119 (Utah 1986). 
Revealing All the Things They'd Enjoy Doing if Men Had a Curfew I Eye-Opening Thread, Oct. 2, 2018, available at https://www.georgetakei.com/women-men-curfew9pm-twitter-2609495872.html (noting that without fear of sexual assault from men, many women would enjoy being able to simply go for a walk at night).

As applied by prosecutors of the Salt Lake District Attorney's Office, the state laws protecting the four Jane Does against sexual assault does not produce the strict uniformity required and operates to disadvantage them as women - who are disproportionately victims of sexual assault in Utah. See Part VII.A, supra. As explained in the sections above, prosecutors in the Office appear to use a "convictability" standard in filing criminal cases, in which the touchstone for filing criminal charges is the likelihood of conviction - and women invariably are not given equal treatment. See Part VII.E, supra. Indeed, women disproportionately are betrayed by the criminal justice process to which they turn for help. See Part VII.F, supra.

By proceeding in this fashion, the District Attorney's Office has transgressed the standards of equal treatment inherent in Utah's Uniform Operation of Laws Clause and the Equal Protection Provision, specifically creating an operation of law that fails to provide equal protection to women. Such "credibility discounting" by prosecutors of women who are sexual assault victims is "a form of discrimination based on group membership.” Tuerkheimer, supra, 166 U. PA. L. REV. at 51. This is precisely the kind of disparate operation of law that this Court can address through the Uniform Operation of Laws Clause and the Equal Rights Provision. 
Finally, reinforcing this need for stronger enforcement is that fact that the Utah Victims' Rights Amendment provides that to “preserve and protect victim's rights to justice and due process, victims of crimes have the[] right, as defined by law, . . to be treated with fairness, respect, and dignity ...." Utah Const., art. I, § 28(1). As explained above, see Part III.D, supra, this provision is a substantive provision, requiring Utah's prosecutors and courts to treat victims fairly. This provision provides significant support for concluding that under-enforcement of laws against sexual violence violates the Utah Constitution.

Fortunately, in this petition, the relief that Jane Does seek is extremely modest. Other recent lawsuits raising similar equal protection claims about under-enforcement of sexual assault laws have sought extensive money damages or class-wide injunctive relief. See, e.g., Amy Smith and Others Similarly Situated v. City of Austin, et al., No. 1:18-cv505 (Dist. Ct. for W.D. Tex. June 18, 2018). Here, in stark contrast, the four Jane Does ask this Court to take the very modest step of simply exercising its undoubted power under Utah Const., art. VIII, $\S 16$, to appoint a prosecutor to pursue criminal charges against their attackers. This Court can accordingly leave for another day the full parameters of relief that might be available under the Uniform Operation of Laws Clause, the Equal Rights Provision, and Utah's Victims' Rights Amendment. All it needs to do here is conclude that the Court-Appointed Prosecutor Provision, read in light of these other three provisions and against the factual backdrop of serious sexual violence 
committed against the Jane Does, requires appointment of a prosecutor to pursue these four cases.

\section{In Light of the Foregoing Facts, Federal Equal Protection Requires Appointment of a Prosecutor for the Jane Does.}

While the focus on this petition has been on state constitutional law, we would be remiss if we failed to also raise an appropriate federal equal protection claim. For the reasons just explained, the Salt Lake District Attorney's Office's failure to pursue criminal charges for the four Jane Does also violates the federal Equal Protection Clause of the Fourteenth Amendment, U.S. Const., art. XIV, § 1. Accordingly, the Jane Does are also entitled to appointment of a prosecutor to protect their rights under the Fourteenth Amendment.

It is a long-standing principle of federal constitutional law that a facially neutral policy still violates the equal protection clause if its application results in discrimination. See, e.g., Yick Wo v. Hopkins, 118 U.S. 356, 362-63 (1886). And, for purposes of federal constitutional review, gender is a suspect class necessitating heightened scrutiny. City of Cleburne, Tex. v. Cleburne Living Ctr., 473 U.S. 432, 440 (1985).

The Equal Protection Clause of the Fourteenth Amendment to the United States Constitution prohibits intentional sex discrimination, including selective or discriminatory enforcement of the law. Whren v, United States, 517 U.S. 806, 813 (1996) (“" $[\mathrm{T}]$ he Constitution prohibits selective enforcement of the law based on considerations such as race"); Elliot-Park v. Manglona, 592 F.3d 1003, 1007 (9th Cir. 2010) (Equal Protection Clause prohibits law enforcement from intentionally discriminating in the 
provision of any services to any degree). In addition to affirmative discrimination against members of protected groups, a failure to take action on behalf of these individuals can constitute unlawful discrimination. See Bell v. Maryland, 378 U.S. 226, 309 (1964) (Goldberg, J., concurring) (“[D]enying the equal protection of the laws includes the omission to protect") (internal quotation marks omitted). The Ninth Circuit has explained specifically that the constitutional right to have law enforcement services delivered in a nondiscriminatory manner "is violated when a state actor denies such protection" to members of protected groups. Estate of Macias, 219 F.3d at 1028. The courts have applied this principle to police under-enforcement of the law where such deliberate under-enforcement adversely harms women. See, e.g., id.; Balistreri v, Pacifica Police Dep't, 901 F .2d 696, 7001 (9th Cir. 1990) (recognizing an Equal Protection claim based upon the discriminatory denial of police services to a victim of domestic violence because of her sex).

Law enforcement action violates the Fourteenth Amendment when a discriminatory purpose is a contributing factor; discrimination need not be the sole motivation for the discrimination to violate the Constitution. Vill. of Arlington Heights $v$. Metro, Hous. Dev. Corp., 429 U.S. 252, 265-66 (1977). Recognizing that discriminatory purpose is rarely admitted or blatant, courts look to the totality of the circumstances to evaluate whether a law enforcement activity was motivated by discriminatory intent and will consider factors that indirectly indicate an intent to discriminate, including evidence of discriminatory impact, evidence of departures from proper procedures, and 
contemporaneous statements by a decision maker or by responding officers. See id. at 265-68; Balistreri, 901 F.2d at 701.

Differential treatment of women premised on sex-based stereotypes, such as stereotypes about the role women should play in society or how they should behave, also violates the Equal Protection Clause. See, e.g., United States v. Virginia, 518 U.S. 515, 517 (1996) (holding invalid explicit sex classification and stating that "generalizations about 'the way women are,' estimates of what is appropriate for most women, no longer justify denying opportunity to women"); Nevada Dep't of Hum. Res. v. Hibbs, 538 U.S. 721, 730 (2003) ("Reliance on such [invalid gender] stereotypes cannot justify the States' gender discrimination" in employment); Mississippi Univ. for Women v. Hogan, 458 U.S. 718,726 (1982) (holding that denying otherwise qualified males the right to enroll in state nursing school violated the Equal Protection Clause). Thus, where a prosecuting agency's failure to adequately respond to sexual assault is premised, at least in part, on sex-based stereotypes, that failure violates the Equal Protection Clause.

The evidence of disparate treatment here is strong enough to support the finding of a discriminatory policy, practice or custom. For example, in Navarro v. Block, 72 F.3d 712, 715 (9th Cir. 1995), the Ninth Circuit was asked to determine whether the defendant county employed a policy or custom of affording less police protection to victims of domestic violence, who are disproportionately women, as compared to other crime victims. $I d$. at 715 . In support of her argument, the plaintiff introduced evidence, through witness testimony, that it was the practice of 911 dispatchers not to classify domestic 
violence calls as Code 2, or "emergency procedure" calls. Id. In reversing the District Court's grant of summary judgment to the defendant, the Circuit held that the plaintiff's evidence that domestic violence calls were not treated as emergencies was sufficient to raise a question of fact as to whether the county maintained a custom or policy of treating domestic violence calls with less priority than other crimes. Id.

But here, the Court need not reach any such sweeping "custom or policy" conclusions. Cf. Deborah Tuerkheimer, Underenforcement as Equal Protection, 57 B.C. L. REV. 1287 (2016) (discussing how custom and practice enforcement of the Fourteenth Amendment to prevent under-prosecution of rape laws coincides with the vision of the Fourteenth Amendment's drafters). Instead, this Court merely needs to determine whether prosecution of four particular sexual assault cases would be in the "interest of justice," as explain in Part III.C, supra. The evidence and analysis presented in this petition strongly supports the conclusion that the four cases before the Court have not been prosecuted due to prosecutorial analysis that disadvantages women in the enforcement of sexual assault laws. ${ }^{29}$ While this might well support a finding of a constitutional violation and resulting broad injunctive or other relief, the petition simply requests a small step toward addressing the problem through simply appointing a

${ }^{29}$ While not presented by this case, similar analysis may help protect women who are victims of other under-prosecuted crimes, such as a domestic violence. See, e.g., Cronan ex rel. State v. Cronan, 774 A.2d 866 (R.I. 2001) (upholding private prosecution in a domestic violence case). Cf. Kenneth L. Wainstein, Judicially Initiated Prosecution: A Means of Preventing Continuing Victimization in the Event of Prosecutorial Inaction, 76 CAL. L. REV. 727, 733 (1988) (calling for ways for domestic violence victims to secure criminal prosecution of abuse, because "the prosecutor's inaction effectively leaves a battered wife vulnerable to continued abuse"). 
prosecutor. Indeed, it is hard to understand how the enforcement of Utah's criminal laws, by action through this State's highest court, could be in any way problematic. See Fox v. MCI Commc'ns Corp., 931 P.2d 857, 860 (Utah 1997) ("the enforcement of a state's criminal code constitutes a clear and substantial public policy"). Given that federal constitutional rights are at stake for these women who have been sexually attacked, the Court should take that modest step.

In pressing the federal equal protection claim, we acknowledge U.S. Supreme Court precedent that, broadly speaking, crime victims have no federal constitutional standing to challenge non-prosecution decisions. See Linda R.S. v. Richard D., 410 U.S. 614, 616-19 (1973) (rejecting private plaintiff's challenge on federal equal protection grounds to state policy of prosecuting only married men for failures to pay child support, and concluding that "in American jurisprudence at least, a private citizen lacks a judicially cognizable interest in the prosecution or nonprosecution of another"). But Linda R.S. is distinguishable from the circumstances presented here. Linda R.S. specifically noted that the Legislature may enact laws "creating legal rights, the invasion of which creates standing, even though no injury would exist without the statute." Id. at 617 n.3. Utah, of course, has done precisely what Linda R.S. envisioned: it has created a constitutional procedure that crime victims are entitled to pursue for appointment of a prosecution in Utah Const., art. VIII, $\S 16$; and (among other rights) it has created broad rights for victims for crime "to justice and due process," as well as to "be treated with fairness, respect, and dignity ...." Utah Const., art. I, § 28(1). These provisions give 
crime victims standing to pursue a federal constitutional claim that might not otherwise exist. $^{30}$

In any event, Linda R.S. should be overruled. While we recognize that the decision is binding on this Court, the decision was simply wrongly-decided. To preserve the possibility of review of this issue before the U.S. Supreme Court, we briefly outline the grounds for overruling the decision in the footnote below. ${ }^{31}$

For all these reasons, appointment of a prosecutor for the four Jane Does is required by federal constitutional law.

J. Jane Doe 2 and Jane Doe 4 Are Also Entitled to Appointment of a Prosecutor Because They Were Examined by a Specially Trained Nurse from Wasatch Forensic Nurses and the Salt Lake District Attorney's Office Refuses to Use Such Nurses as Witnesses in Their Criminal Cases.

One final point is worth brief mention as to why a court-appointed prosecutor is necessary to handle the sexual assault cases of Jane Doe 2 and Jane Doe 4. Both women quite promptly reported the crimes to law enforcement. Accordingly, the possibility of gathering physical evidence to corroborate their accounts of the crime existed. Both victims were, indeed, examined by the Wasatch Forensic Nurses (WFN). As explained in

${ }^{30}$ We discuss standing issues further in Part IX, infra.

31 The case for overruling Linda R.S. was well articulated by Yale Law Professor Abraham Goldstein. As he explained: "Even on its own premises, the Supreme Court did not try very hard to find 'standing' for the plaintiff under the usual criteria. The challenged action had certainly caused her 'injury in fact.' The interest she sought to protect was as certainly 'arguably within the zone of interests ... regulated by the [nonsupport] statutes.' Linda R.S. was more a decision on the merits than on standing." Abraham S. Goldstein, Defining the Role of the Victim in Criminal Prosecution, 52 MIsS L.J. 515, 550-53 (1982); see also Donald G. Gifford, Equal Protection and the Prosecutor's Charging Decision: Enforcing an Ideal, 9 GEO. WASH. L. REV. 659, 712 (1981) ("The Court's holding in Linda R.S. is questionable"). 
the attached expert affidavit by Executive Director Deborah Koons-Beauchamp [App. at 300-05], WFN is perhaps Utah's premier organization of sexual assault nurse examiners (or SANEs). [App. at 301.] The nurses in that organization are highly trained to perform objective and unbiased examinations in the wake of reports of possible sexual assault. [App. at 301.] The nurses respond 24 hours a day, 7 days a week to hospitals and other medical clinics along the Wasatch Front. [App. at 302.] Of course, as highly trained medical professionals the nurses who work for WFN must follow all applicable legal and ethical standards, such as the Health Insurance Affordability and Accountability Act (HIPPA). [App. at 301.]

Historically and unsurprisingly, Wasatch Forensic Nurses has worked hand-inhand with the Salt Lake County District Attorney's Office to present to juries the most probative evidence in sexual assault cases. For example, WFN has historically been part of a weekly Multi-Disciplinary Team (MDT) meeting to evaluate the facts of various cases. [App. at 302-03.] WFN also provided expert witness testimony about patients who they have examined. [App. at 303.] As the first medical responders in many cases to reports of rape and sexual assault, these nurses may be able to provide information to juries evaluating these cases that no other witnesses can provide. [App. at 303.]

Remarkably, as of May 2018, the Salt Lake County District Attorney's Office decided that it would no longer work closely with the dedicated nurses of WFN. [App. at 303.] The Office had concluded that because WFN considers its nurses "medical" nurses whose forensic medical examinations are constrained by HIPAA standards, that the 
Office would no longer be using WFN's services at the MDT meetings. [App. at 303.] Even more curiously, the Office has decided that it will not use Wasatch Forensic Nurses as expert witnesses on cases, even when a WFN nurse performed the initial examination on the victim involved in the case. [App. at 303.] The Office has warned WFN that unless it stops adhering to medical practices and policies required by HIPAA, the WFN nurses would not be called upon to testify regarding the circumstances of the examination of the sexual assault victims that they have performed. [App. at 304.]

This recent change in policy was shocking, given that WFN have always had a positive working experience with the Salt Lake County District Attorney's office in the past. [App. at 304.] WFN is concerned that, because of this punitive action by the Office, they will not be able to provide expert testimony for their patients in sexual assault cases or that otherwise-viable cases may not be selected for prosecution. [App. at 304.] While WFN remains hopeful that the Office will reconsider, [App. at 304], as of this time, the nurses are not being called as expert witnesses.

Jane Doe 2 is directly affected by this on-going dispute. She was forensically examined by a WFN nurse. [App. at 304-05.] The findings of this specially trained nurse, corroborated Jane Doe 2's allegations. [App. at 305.] It is critical that this particular nurse be allowed to report on Jane Doe 2 situation, so that the details of her case can be fully and accurate presented to the prosecution and the jury. [App. at 305.]

Similarly, Jane Doe 4 is harmed by this on-going dispute. A SANE from Wasatch Forensic Nurses performed the examination of Jane Doe 4 - an examination that 
corroborated her allegations of anal penetration by finding a rectal tear. [App. at 305.] If WFN is prohibited from providing expert witness testimony on behalf of Jane Doe 4, then it is likely that case details will not be presented as objectively, completely and accurately as they would be by a surrogate expert witness. [App. at 305.]

It should go without saying that sexual assault victims such Jane Doe 2 and Jane Doe 4 have little choice in which SANE organization they are sent to for performance of a sexual assault exam. Yet these SANE programs are a vital part of efforts to ensure that sexual assault victims receive the treatment and services that they need to recover from sexual violence. See R. Campbell, D. Patterson \& L. Lichty, The Effectiveness of Sexual Assault Nurse Examiner (SANE) Programs: A Review of Psychological, Medical, Legal, and Community Outcomes, 6 Trauma, Violence, And Abuse 1, 31 (2005). For Jane

Doe 2 and Jane Doe 4 to have their prosecutions handled in a less effective way because they were examined by nurses from Wasatch Forensic Nurses, while other victims do not have these problems, is the height of irrationality. Fortunately, this Court can simply eliminate this problem by appointing prosecutors from outside the Salt Lake District Attorney's Office to handle their cases.

\section{For Judicial Economy and Efficiency, the Court Should Defer Briefing and Decision About Who Should Be Appointed as the Prosecutor Until It Has Decided What the Standards are for Appointment.}

For all the foregoing reasons, the four Jane Does are each entitled to appointment of a prosecutor under Utah Const., art. VIII, § 16. The only remaining question for this Court would then be whom that prosecutor should be. For judicial efficiency and 
economy, this Court should bifurcate the issues raised by this petition and defer the issue of the identity of the prosecutor until later briefing.

The obvious first question presented by this petition is whether the Jane Does are entitled to appointment of prosecutors. If this Court answers that question "no", then no further issues are presented. If the Court answers that question "yes" - as we believe the foregoing evidence and argument makes abundantly clear it should - then the Court would need to consider whom it should appoint as a prosecutor. As the Court can determine from the lengthy briefing already provided by this petition, the issues surrounding the initial question of the standards surrounding appointment of prosecutors are complicated ones of first impression. Accordingly, the Jane Does simply ask the Court to determine that question first. If the Court rules in the victims' favor, then the Court could proceed to the secondary question of who should be appointed to prosecute the cases.

Three possibilities for a court-appointed prosecutor immediately spring to mind. First, the Court could ask the Utah Attorney General's Office to prosecute the cases. The Utah Attorney General's Office has many experienced prosecutors within it and perhaps that Office might be willing to serve as a backstop in cases where a County Attorney or District Attorney has failed or refused to prosecute a viable criminal case.

Second, the Court could ask a public prosecutor in an adjoining County to pursue a well-founded petition under article I, $\S 16^{32}$ This is the standard practice of "conflicts"

\footnotetext{
${ }^{32}$ The Court should not ask the same prosecuting office that declined the case initially to pursue the prosecution. After a formal declination, a prosecuting office has clear
} 
cases in this State, and perhaps it could simply be extended to court-appointed prosecutions as well.

Third, the Court could appoint one or more of the undersigned attorneys for the Jane Does to handle the matter. The undersigned attorneys include several experienced prosecutors who possess the experience and ability to handle complex sexual assault cases. There is no need for a prosecutor in this State to be an elected public official. See, e.g., State v. Balfour, 2008 UT App 410, ๆ 36, 198 P.3d 471, 481 ("We are also unpersuaded by Balfour's claim that he is entitled to supervisory review by an elected official in the prosecution of the charges against him.").

To be sure, any such court-appointed prosecutor would have to follow all applicable rules of ethics for public prosecutors. See generally Roger A. Fairfax, Jr., Delegation of the Criminal Prosecution Function to Private Actors, 43 U.C. DAVIS L. REV. 411, 453-54 (2009). That is not a problem here, and accordingly no ethical impediment to their appointment exists. Moreover, the prosecution would proceed by virtue of this Court's authorization in the name of the State. Cf. Gregory v. Shurtleff, 2013 UT 18, ๆ 77, 299 P.3d 1098, 1123 (Lee, J., concurring in part and dissenting in part) ("I can find no instance of a private party [in Utah] indicting or trying a criminal suspect independent of state involvement). The prosecution would thus simply follow the welltrodden path for criminal cases in this State.

perceived, if not actual, conflict of interest, because it may wish to lose the case to prove that its initial non-prosecution decision was correct. 
Considering which of these three options - or other options that might be possible - is best addressed after the Court has ruled on the merits of the underlying petition. The Court's ruling is likely to shed considerable light on the scope and application of Utah's Court-Appointed Prosecutor Provision, which will be helpful in considering who should act as a prosecutor.

\section{The Jane Does Have Standing to File This Petition, But No Other Entity or Person is a Party to This Petition.}

Finally, it is worth discussing a few points about how subsequent proceedings on this petition should unfold. In particular, issues of "standing" should be considered. While the Jane Does each have standing to appear before this Court to seek appointment of a prosecutor for violent crimes committed directly against them, the four possible defendants (Richards Roes 1 through 4) are not entitled to appear as parties in proceedings associated with this petition.

The four Jane Does naturally have "standing" to pursue judicial appointment of a prosecutor for crimes of violence committed against them. Any other conclusion would simply render the Court-Appointed Prosecutor Provision effectively inoperative. If a woman who has been raped lacks sufficient injury to seek appointment of a prosecutor to pursue her attacker, then no one will have sufficient injury - rendering the provision a dead letter. Cf. Allen v. Rampton, 463 P.2d 7, 11 (Utah 1969) (cautioning against constructions that render provisions a nullity).

Historically, it was well understood that a victim could seek a prosecution for a case involving herself. For example, private prosecutions in Philadelphia were used by 
women to prosecute sex crimes. See Allen Steinberg, The Transformation of CRIMINAL JustiCe: PhiladelPhiA 1800-1890 at 69-71 (1989). Reflecting on such history, Justice Stevens (among others) has recognized that the tradition of private prosecution means that " $[t]$ he interest in punishing the defendant and deterring violations of law by the defendant and others was sufficient to support the 'standing' of the private prosecutor even if the only remedy was the sentencing of the defendant to jail or to the gallows." Steel Co. v. Citizens for a Better Environment, 523 U.S. 83, 128 (1998) (Stevens, J., concurring in the judgment).

To be sure, there is an argument under federal constitutional law that a victim may lack standing to seek the initiation of a federal prosecution. See Linda R.S. v. Richard D., 410 U.S. 614, 619 (1973) (discussed in Part VII.I, supra). However, such a conclusion appears to rest on the "case and controversy" requirement contained in the federal constitution, see Mikhail v. Kahn, 991 F. Supp. 2d 596, 637 (E.D. Pa. 2014) - a requirement that does not exist under Utah constitutional law. See Gregory v. Shurtleff, 2013 UT 18, \ 12, 299 P.3d 1098, 1102 ("Unlike the federal system, the judicial power of the state of Utah is not constitutionally restricted by the language of Article III of the United States Constitution requiring 'cases' and 'controversies,' since no similar requirement exists in the Utah Constitution."). Indeed, as a matter of state constitutional law, this Court may grant standing where matters of great public interest and societal impact are concerned.” Id. at $₫ 12$ (citing Jenkins v. State, 585 P.2d 442, 443 (Utah 1978)). It is hard to imagine very many issues of greater public importance and social 
impact than the prosecution of sexual violence against women. And it is also equally clear that there is no one "who has a greater interest in the outcome of the case" than the women who have been sexually assaulted and thus "the issue is unlikely to be raised at all” if the Jane Does are denied standing. Gregory v. Shurtleff, 2013 UT 18, ๆ 13, 299 P.3d 1098, 1103.

On the other hand, the four putative defendants are not "injured" in the eyes of the law if criminal charges are authorized against them. Generally, putative defendants have no right to present evidence during criminal investigations. For example, it is generally recognized that defendants have no right to present testimony to grand juries who may be considering indicting them. See, e.g., United States v. Fritz, 852 F.2d 1175 (9th Cir. 1988); State v. Jessen, 633 P.2d 410 (Ariz. 1981); Moczygemba v. State, 532 S.W.2d 636 (Tex. Crim. 1976); Alaska R. Crim. P. 6(p) (grand jury has "no duty to hear evidence on behalf of the defendant"); Nev. Rev. Stat. § 172.145 (grand jury "not bound to hear evidence for the defendant"); see also 1898 Utah Code of Criminal Procedure $\S 4715$ ("The grand jury shall not be bound to hear evidence for the defendant"). The reason, of course, is that defendants have ample rights protecting them in the criminal justice process against wrongful conviction - once a prosecution is initiated. See Utah Const. art. I, $\S 12$ (listing rights of "accused persons" that apply only in "criminal prosecutions"). Because a defendant has no right to avoid the filing of criminal charges when probable cause exists for those charges, the four Richard Roes are not parties to this petition. 
Similarly, Salt Lake County (represented by the Salt Lake District Attorney's Office) is not a party to this petition. Salt Lake County and its District Attorney suffer no cognizable injury if, pursuant to constitutional power under Utah Const., art. VIII, § 16, this Court authorizes a criminal prosecution for the crimes of sexual violence committed against Jane Doe 1, Jane Doe 2, Jane Doe 3, and Jane Doe 4. Any such authorization does not "adversely affect" the District Attorney's Office. See Utah Chapter of Sierra Club v. Utah Air Quality Bd., 2006 UT 74, \20, 148 P.3d 960 (discussing “injury” requirement for standing).

By the same reasoning, the Utah Attorney General's Office is not a party to this petition. Just as with local prosecutors, the Attorney General's Office is not adversely affected if this Court authorizes the filing of criminal charges. Indeed, the Attorney General's Office will have a later opportunity to intervene in any criminal case that this Court authorizes, see Part III.B, supra, thereby further reducing an (already non-existent) chance that it will be somehow injured.

Nonetheless, the Jane Does acknowledge that the Court has discretion to call for the views of the Attorney General on important matters of state constitutional law, and the Jane Does would have no objection to the Court doing so here. ${ }^{33}$

\footnotetext{
${ }^{33}$ The Jane Does also believe that various organizations may like to file an amicus brief in support of their petition. Any briefing schedule that the Court establishes should provided an opportunity for amicus support, as well as providing the Jane Does with an opportunity to reply to any arguments made against their petition.
} 


\section{The Court Should Hold Oral Argument on this Important Petition.}

The victims believe that the issues they raise are extremely important and of first impression. The issues involve important and fundamental state constitutional (and federal constitutional) issues concerning the role of victim-initiated prosecution in protecting women and girls in this State from rape and other crimes of sexual violence.

Accordingly, the Court should hold oral argument on Jane Does' petition. ${ }^{34}$

${ }^{34}$ Because the issues presented are novel and of first impression, should the petition suffer from any procedural deficiencies, the Jane Does would respectfully request leave to amend this petition after receiving guidance from this Court. 


\section{CONCLUSION}

This Court has previously called for litigants to present state constitutional issues so as to fully develop the protections set out in Utah's organic law. See, e.g., Brigham

City v. Stuart, 2005 UT 13, ๆ 10, 122 P.3d 506, overruled on other grounds, 547 U.S. 398 (2006). The Jane Does come before this Court to do exactly that.

The framers of Utah's Constitution anticipated cases in which public prosecutors would fail or refuse to prosecute well-founded criminal cases and provided a mechanism for the courts to permit victim-initiated prosecution. And yet, for the more than 120 years of this State's history, it appears that Utah's judiciary has seldom (if ever) employed that mechanism. This has effectively transformed a system constitutionally designed to give prosecutors only "primary responsibility" for deciding whether a prosecution should begin, Utah Const., art. VIII, $\S 16$, into one where they effectively exercise exclusive and unreviewable control.

The time for this Court to invoke its constitutionally conferred power has now arrived. At a point in this country's history where throughout the nation intense concern exists about the criminal justice system's treatment of sexual assault victims, four women have suffered sexual violence in clear violation of Utah's criminal laws. And yet prosecutors have failed and refused to enforce those laws. Under the Utah Constitution (and federal constitution), this Court can redress that injustice - and should do so.

For the foregoing reasons, this Court should appoint a prosecutor for Jane Doe 1, Jane Doe 2, Jane Doe 3, and Jane Doe 4 pursuant to its specific authority under Utah 
Constitution, article I, section 16. For the convenience of the Court, proposed Criminal Informations to be filed in each of the four cases are annexed to this petition. The Janes Does also request that the Court direct briefing as to the appropriate prosecutor to be appointed.

DATED this $16^{\text {th }}$ day of October, 2018.

/s/ Paul G. Cassell

Paul G. Cassell

UtAH APPELLATE CLINIC

(counsel of record)

Heidi Nestel

Bethany Warr

UtAH CRIME VICTIMS' LEGAL CLINIC

Meg Garvin

NATIONAL CRIME Victim LAW INSTITUTE

(pro hac vice application to be filed)

Greg Ferbache

FERBRACHE LAW

Aaron Smith

STRONG AND HANNI

Attorneys for Jane Doe 1, Jane Doe 2, Jane

Doe 3, and Jane Doe 4 


\section{Certificate of Compliance}

I hereby certify that this petition does not violate any page limitations set forth in the Utah Rules of Appellate Procedure, because no page limitation for a petition under Utah Const., art. I, $\S 16$, is set forth in the Rules. In addition, in the interests of judicial economy, this petition is filed on behalf of four crime victims (and supporting groups, including the Utah Crime Victims' Legal Clinic and the National Crime Victim Law Institute). If the petition is viewed as analogous to a principal appellate brief, then each of the four victims would be entitled to file separate 14,000-word principal briefs. By filing a single petition, the four victims have avoided duplicative arguments. If the Court believes that any page limitations are applicable to this petition, the victim-petitioners would request an opportunity to move to exceed those page limitations in view of the importance, novelty, and complexity of the state constitutional (and federal constitutional) issues addressed in this petition.

This petition also complies with the type face requirements of the appellate rules as well as Utah R. App. P. 21(g) regarding public and non-public filings.

DATED this $16^{\text {th }}$ day of October, 2018.

/s/ Paul G. Cassell 


\section{Certificate of Service}

As discussed in the penultimate section of the petition, above, the petitionervictims do not believe that any other entity or individual is a party of their petition. Nonetheless, and without prejudice to their right to assert that position, the petitionervictims have today, October 16, 2018, provided a copy of their petition to the Appellate Section of the Utah Attorney General's Office via email to criminalappeals@agutah.gov and to the Utah Solicitor General at notices@agutah.gov.

/s/ Paul G. Cassell 